Studies in Science and Technology Education Linköping University No. 100

\title{
Teknik i förskolan - att motverka traditionella könsroller
}

\section{- En aktionsforskningsstudie -}

\author{
Johan Boström
}

I..VU

Institutionen för samhälls- och välfärdsstudier

TekNaD. Teknik, naturvetenskap och didaktik Linköpings universitet, SE-601 74 Norrköping Norrköping [2018] 
(C) [Johan Boström, 2018] 


\title{
Teknik i förskolan - att motverka traditionella könsroller \\ - En aktionsforskningsstudie -
}

Av

Johan Boström

April 2018

ISBN 978-91-7685-307-8

Studies in Science and Technology Education

No. 100

ISSN 1652-5051

\begin{abstract}
This study shows that developing a gender sensitive technology education in a preschool setting is a very complex and multifaceted task. The preschool, and the preschool teachers, are expected to help the children develop their technological awareness and interest in technology without being limited by traditional perspectives on gender. However, as research has shown, teachers' expectations of children's behaviour and interest in leisure time activities are gendered and reflect historically developed gendered roles in relation to technology. As this study shows there is a palpable risk of the preschool teachers on one hand focusing on girls and boys as homogenous groups, where a single individual gets to represent the group as a whole; and on the other hand, missing gender structures if the mindset is that gender does not factor into their treatment of the children at all - that they, automatically in their role as techers, act gender neutral. In this study, the pedagogical conversation was important for the teachers possibility to reflect about their own preconceptions. However, the conversation did not seem to be enough, it was also important for the teachers to get to see and reflect on how they actually interacted with the children in the technological activities. Only then did the teachers actually start to question their preconceptions and began to discuss new ways of acting.
\end{abstract}

Keywords: (teknikdidaktik, teknik, förskolan, genus, könsroller, aktionsforskning)

Institutionen för samhälls- och välfärdsstudier TekNaD. Teknik, naturvetenskap och didaktik Linköpings universitet, SE-601 74 Norrköping 


\section{Förord}

I skrivande stund är det fyra år sedan jag påbörjade min färd fram mot den här licentiatavhandlingen. Denna resa hade inte varit möjlig utan en rad människor som har min innerliga tacksamhet.

Jonas Hallström, Claes Klasander, Tomas Ginner och Björn Citrohn som alla, på ett eller annat sätt, hjälpte mig att komma förbi en stor initial tröskel. Mina doktorandkollegor i Norrköping som gjorde allt så mycket roligare. Cecilia Axell som under årens lopp fungerat som mitt inofficiella bollplank. Niclas Åhman vars vänskap, stöd och input varit av ovärderlig hjälp. Mina handledare, Magnus Hultén och Per Gyberg, utan vars hjälp inget av detta hade varit möjligt.

Maria, vars ord för arton år sedan stakade ut riktningen för mig; Malte och Tilda, som ibland fått stå ut med en väldigt stressad pappa jag älskar er alla tre.

Och till sist, tack till en grävmaskinist som alltid pushade mig att inte bli vid min läst.

Kalmar i mars 2018

Johan Boström

Till Boje. 
Innehållsförteckning

Förord iv

1 Inledning .............................................................................................

2 Syfte och frågeställning ...........................................................................11

3 Bakgrund, teori och tidigare forskning ………....................................... 12

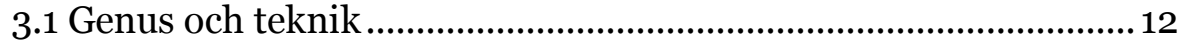

3.1.1 Genus.................................................................................12

3.1.2 Teknikens historiska genusprägling.................................15

3.1.3 Teknik och manlighet .....................................................18

3.2 Förändring och identitet ....................................................................24

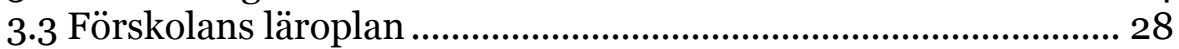

3.4 Värdegrundsarbete och värdepedagogoik......................................29

3.5 Tidigare forskning kopplat till teknik och genus i förskola och

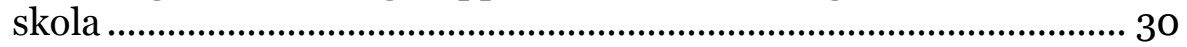

3.5.1 Olika utgångspunkter i jämställdhetsarbetet ....................31

3.5.2 Pedagogens roll .......................................................................35

3.5.3 Pedagogen och tekniken ........................................................39

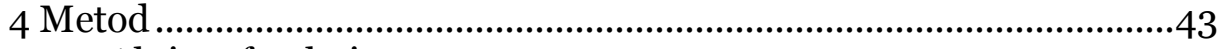

4.1 Aktionsforskning............................................................................43

4.2 Aktioner .......................................................................................... 45

4.3 Verktyg.............................................................................................. 4

4.4 Urval ........................................................................................... 48

4.5 Analys .........................................................................................49

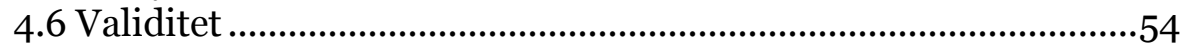

4.7 Etiska överväganden.......................................................................56

4.7.1 Etiska överväganden i förhållande till barnen som ingick $i$ studien ............................................................................................57 4.7.2 Etiska överväganden $i$ förhållande till deltagarna $i$ studien och andra vuxna ...............................................................59

4.7.3 Etiska överväganden $i$ förhållande till min egen roll $i$ studien ......................................................................................62

4.8 Urvalet av filmsekvenser från verksamhetsaktionerna .................64

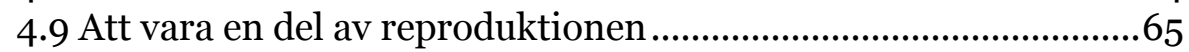

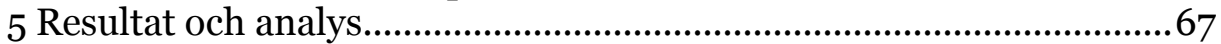

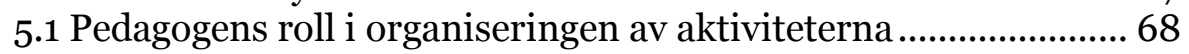

5.2 Innehåll som barnen får möta ................................................... 82

5.3 Barnens egenskaper och karaktärsdrag .........................................93

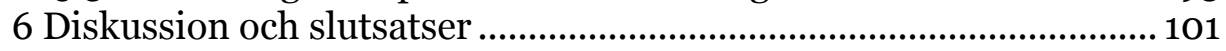

6.1 Pedagogens roll i organiseringen av aktiviteterna....................... 101

6.2 Innehåll som barnen får möta ......................................................106

6.3 Barnens egenskaper och karaktärsdrag ......................................111

6.4 Utmaningar och möjligheter.......................................................... 114

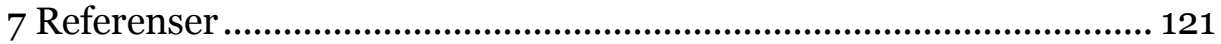


Bilagor

Bilaga 1 - Brev till vårdnadshavare

129

Bilaga 2 - Sammanfattning av mötesaktioner, verksamhetsaktioner och informationsmöten.. 
Kapitel 1

\section{Inledning}

Förskolan har både ett uppdrag att utveckla barns förmågor kopplade till det tekniska kunskapsområdet och ett uppdrag att se till att alla barn i förskolan får möjlighet att utveckla intresse och förmågor utan att bli begränsade av stereotypa perspektiv. Samtidigt är förskolan som institution inte separerad från samhället i övrigt, och de strukturer av traditionella förväntningar på barnens beteende och intresse för teknik som existerar där. Teknikens könspräglade historia kan potentiellt göra att det tekniska området bjuder förskolans personal på stora utmaningar i relation till dessa uppdrag.

Barn lär sig i tidig ålder vad som anses vara korrekt beteende för kvinnor och män (Kimmel, 2000). Det finns indikationer på att denna process startar så tidigt som mellan två till fem års ålder (Lyon, 1991; Trepanier-Street \& Romatowski, 1999; Turja et al., 2009). Med hjälp av en medvetenhet om samhällets sätt att kategorisera utifrån motsatsparet kvinnligt/manligt börjar barnen själva att avkoda sin omgivning. De ser hur vuxenvärlden agerar och talar, de observerar hur andra reagerar på vad de gör och säger, och utvecklar på detta sätt tankar om vad som är passande agerande, passande aktiviteter, passande leksaker, passande yrken, etcetera, för kvinnor respektive män (Browne, 1991; Lyon, 1991; MacNaughton, 1997; SOU2004:115, Trepanier-Street \& Romatowski, 1999). Denna kategorisering tar sin början i den familj ett barn växer upp i, bland annat utifrån hur genusförståelsen och genusstrukturen ser ut hos föräldern/föräldrarna. Många föräldrar har olika förväntningar på vad deras barn behöver och hur de ska behandlas beroende på om det är en flicka eller en pojke. Detta anses ha att göra med att föräldrarna själva under sitt liv har socialiserats in i en förstålse om hur flickor och pojkar i olika åldrar "bör" bete sig. Föräldrarnas agerande kring barns aktiviteter, exempelvis utifrån vilka leksaker barnet vill leka med, är något som snabbt kan snappas upp av barnet och som barnet sedan kan anpassa sig efter. Det har framkommit att om en förälder uttrycker ett missnöje med att barnet väljer att leka med en viss artefakt, exempelvis en viss leksak, så kan detta 
göra att barnet så småningom ändrar sina preferenser och väljer bort denna artefakt (Kimmel, 2000). Denna process, där barnen lär sig kulturbundna sätt att förstå sig själva och vad som förväntas av pojkar respektive flickor, sker också i mötet med andra omsorgspersoner, exempelvis pedagoger i förskolan. Förväntningarna på barnen, utifrån historiskt sett normativa institutionella och kulturella bilder och ramar kopplat till genus, påverkar de möjliga roller och positioner som barn har möjlighet att inta i förskolans aktiviteter (Hundeide \& Järvå, 2006). Detta är institutionella och kulturella ramar där maskulinitet verkar stå över femininitet (Ärlemalm-Hagsér \& Pramling Samuelsson, 2009).

Under åtminstone de senaste 500 åren har teknik haft en tydlig koppling till manlighet. Denna könskodning har i synnerhet vuxit sig stark under de senaste 100 - 200 åren, från industrialiseringen och framåt, då teknikbegreppet i dess moderna bemärkelse utvecklades och knöts till en industriell och manlig verksamhetssfär (Berner, 1999; Mellström 1999; Faulkner, 2003; Oldenziel, 1999). Den resulterande samhälleliga bilden har varit att ett tekniskt kunnande och ett tekniskt handlag ofta jämställts med manlighet (Berner, 2003a; Mellström, 2003, Oldenziel; 1999). Tekniska yrken, utbildningar och hobbys har i mångt och mycket varit en arena som män har haft betydligt enklare tillgång till än kvinnor (Oldenziel, 1999). Dessa begränsningar för kvinnor har historiskt sett handlat om både en fysisk och mental utestängning. Ingenjörsyrket kan användas för att exemplifiera detta. Den första kvinnliga ingenjören i Sverige examinerades 1917 (Chalmers, 2017) och 1921 blev det tillåtet för kvinnor att studera vid KTH (KTH, 2009). Även om kvinnor har haft tillgång till denna slags utbildning i cirka 100 år så är det betydligt lägre andel kvinnor som valt att söka denna än andelen män. På 70-talet var andelen 10\% och 2013 var andelen knappt 25\% (SalminenKarlsson, 2003; SCB, 2013). En anledning till att det inte är lika många kvinnor som män kan ha att göra med att ingenjörsyrket som institution från början är skapat av män, för män, och ses av människor i stort som ett manligt yrke (Salminen-Karlsson, 2003). Denna skeva fördelning existerar inte enbart inom det smala fält som är ingenjörsyrket utan kan även sägas genomsyra tekniken i samhället som helhet (Berner, 1999). 
Teknik utgör på ett eller annat sätt en stor del av individers vardagsliv, inte bara genom att många politiska beslut inrymmer teknik eller att ny teknik kan påverka samhällets utveckling, utan även genom att människor formar sina identiteter i förhållande till tekniken (Berner, 1999). Det blir i sådana fall ett demokratiproblem om en del av medborgarna inte har samma tillgång till den tekniska sfären. Regler kring vem som räknas som en teknikexpert eller teknikintresserad person, hur interaktioner med teknik bör ske och vilka värden som är viktiga i detta, har ofta formulerats och definierats av män, för män, och i grund och botten stängt ute kvinnor från gemenskapen (Berner \& Nyborg, 2004). Ur ett historiskt perspektiv har det mestadels varit män som haft inflytande över utveckling och konstruktion av tekniska system och artefakter (Berner, 2003c; Faulkner, 2001, 2003).

Generellt sett uppmuntras pojkar av samhället till en lekfull inställning till den traditionellt sett manliga tekniken där ledorden är skaparglädje, lekfullhet, tävlan och risktagande. Detta intresse förvaltas sedan vidare genom att dessa pojkar/män uppmuntras och förväntas skaffa sig en utbildning inom dessa tekniska fält, och får därmed en större åtkomst till samhällets maktpositioner och möjlighet att påverka framtida teknik. Följden blir att den starka kopplingen mellan en viss slags teknik och manlighet blir mycket svår att bryta (Berner, 1999; Connell, 2009). På detta sätt blir alltså flickor/kvinnor utestängda från en del av teknikens korridorer.

Förskolan är en arena där barn skapar sig en förståelse för, och formar attityder till, teknik utifrån ett genusperspektiv (Berner, 2003b). Detta formande av könsmönster sker bland annat utifrån personalens förhållningssätt, det material som barnen erbjuds, innehållet i aktiviteterna, och de ramar som styr verksamheten (SOU 2006:75). Tidigare forskning visar att traditionella könsmönster i högre grad reproduceras i förskolan än att de utmanas (Eidevald, 2009; Hundeide \& Järvå, 2006; Månsson, 2000). En del av arbetet med att utmana stereotyper kan vara att pedagogerna fördjupar sin förståelse av sin egen roll i reproduktionen av rådande genusstrukturer (SOU 2004:115). En ökad förståelse för de institutionella och kulturella ramar som 
omgärdar aktiviteter i förskolan kan ge pedagogerna bättre förutsättningar att utmana traditionella könsmönster. Det blir därför intressant att undersöka vilka möjligheter och utmaningar som kan finnas i förskollärares arbete med att utveckla aktiviteter i förskolan inom området teknik och som kan utmana traditionella könsmönster.

För att undersöka detta har aktionsforskning valts som metodologisk utgångspunkt. Aktionsforskning inom förskola och skola utgår från att det är deltagarna själva, i detta fall pedagogerna, som genom ett nära samarbete med forskaren, kan lösa ett problem inom den egna verksamheten (Rönnerman, 2010, 2012a: Westlander, 2006). Genom en aktionsforskningsstudie kan pedagogerna tillägna sig redskap för att förstå vardagliga händelser på ett nytt sätt (Nylund et al., 2010). Exempelvis kan medverkan hjälpa dem att utmana sin egen genussyn (Andersson, Hussenius \& Gustafsson, 2009). 
Kapitel 2

\section{Syfte och frågeställning}

Studien syftar till att undersöka hur traditionella könsroller påverkar yngre barns förutsättningar att utveckla intresse för och förmågor i teknik. Detta görs med hjälp av aktionsforskning. Specifikt försöker studien att svara på följande frågor:

- Vilka didaktiska resonemang blir synliga i planering och utvärdering av aktiviteter kopplade till teknik och genus i förskolan?

- Vilka utmaningar och möjligheter finns i förskolans arbete med genus och teknik?

Med didaktiska resonemang menas i detta fall diskussioner som berör vad för slags ämnesstoff barnen ska ges möjlighet att möta och varför; hur dessa möten (de i studien så kallade verksamhetsaktionerna) kring detta ämnesstoff ska utformas och varför; samt hur pedagogerna beaktar barnens erfarenheter och medverkan när verksamhetsaktionerna utformas och utvärderas. Den första frågan handlar alltså om de didaktiska frågorna vad, varför, hur och för vem? Underlaget för analysen av de didaktiska resonemangen baseras på de så kallade mötesaktionerna (för mer information se kapitel 4.5 och bilaga 2).

Den andra frågan besvaras genom en analys av de didaktiska resonemangen i relation till målet att utveckla en teknikdidaktisk verksamhet i förskolan som inte begränsas av traditionella könsroller. Vilka möjligheter och utmaningar stöter lärarna på i förändringsarbetet, så som det uttrycks i mötesaktionerna? 
Kapitel 3

\section{Bakgrund, teori och tidigare forskning}

I följande kapitel kommer jag att belysa den forskning och de teorier som har legat till grund för studien.

\subsection{Genus och teknik}

I följande delkapitel kommer jag först att göra en definition av genus, efter detta kommer jag att beskriva teknikens historiska koppling till genus och hur det går att se på teknik utifrån maskulinitetsnormer.

\subsubsection{Genus}

Som diskuterats i inledningen så finns det en mycket stark koppling mellan teknik och manlighet. Exempelvis existerar det i många samhällen en bild av mannen som den tekniskt kompetente och kvinnan som icke-teknisk (Connell, 2009; Mellström, 1999). Eftersom jag är intresserad av dessa och liknande genusstrukturer kan det vara intressant att först definiera hur det går att se på begreppet genus. På grund av den starka kopplingen mellan manlighet och teknik har jag valt att utgå från Raewyn Connells (2009) och Michael Kimmels (2000) förklaringsmodeller av genus. Både Connell och Kimmel är ledande forskare inom fältet och har framförallt studerat hur manlighet konstrueras i en samhällelig kontext, där manliga genusidentiteter ofta placeras högre än kvinnliga genusidentiteter. Kimmel (2000) beskriver att begreppet genus innehåller aspekter som makt och jämställdhet, och att genus, tillsammans med faktorer som etnicitet och klasstillhörighet, är grundpelarna för att både förstå sociala samspel och individers identitetsskapande. Connell (2009) menar att genus är ett multidimensionellt koncept där sexualitet, arbete, makt och identitet skapar en helhet.

Connell (2009) beskriver att ett vanligt sätt att klassificera människor i samhället utgår från dikotomin kvinnligt/manligt och att många personer i samhället identifierar sig som just kvinna eller man. Ur ett rent biologiskt perspektiv föds de flesta som hane eller hona, men detta biologiska kön har väldigt lite att göra med 
en persons definition av vad det innebär att vara man respektive kvinna, vad som anses kvinnligt respektive manligt (Kimmel, 2000). Kimmel menar att denna uppdelning av människor utifrån deras biologiska kön går att hitta hos i stort sett alla samhällsgrupper på jorden och har sin förklaring i att människor ofta definierar sig själva genom att sätta sig i relation till vad de inte är - det vill säga "de andra". Dessa andra kan handla om etnicitet, sexuell läggning, och så vidare. För mannen blir den andra traditionellt sett en kvinna och vice versa.

what we now about being a man has everything to do with what it means to be a woman; and what we know about being a woman has everything to do with what it means to be a man. (2000, sid. 85)

Enligt Connell (2009) riskerar sådana vardagdefinitioner av vad som är "manligt" respektive "kvinnligt" att bli problematiska eftersom att genus inte handlar om skillnader, utan om relationer. Det handlar om de sociala sammanhang där grupper och individer interagerar med varandra.

Genus är inte ett uttryck för biologi, och inte heller en fast dikotomi i människors liv eller personlighet. Det är ett mönster i våra sociala arrangemang och i de dagliga aktiviteter eller praktiker som de arrangemangen styr. (sid. 24 - 25)

Den syn på genus som jag använt mig av i den här studien utgår alltså från en tanke om att det är ett icke jämställt samhälle som skapar de skillnader som i vardagen går att observera mellan könen, inte motsatsen - att "naturliga" skillnader mellan könen skapar det icke jämställda samhället.

Connell (2009) menar att det finns spelregler i samhället som utgår från vissa förväntningar på oss som individer. Dessa anger vad som är ett lämpligt genusrelaterat beteende, det vill säga vad som är ett lämpligt beteende beroende på om en individ anses vara kvinna eller man. Dessa sociala spelregler med utgångspunkt i maskulinitets- och femininitetsnormer, i motsatsparen man/pojke och kvinna/flicka, påverkar individers sätt att se på sig själva från tidig ålder och spelar en stor roll under en längre period av en individs uppväxt (Connell, 2009; Kimmel, 2000). 
Både Connell (2009) och Kimmel (2000) menar dock att det inte enbart går att se på kvinnlighet och manlighet som något som påtvingas individen av samhällets sociala normer. Individer konstruerar även sig själva som maskulina/feminina i vardagen då de förhåller sig till det utrymme i rådande genusstruktur som de blivit tilldelade. Kimmel (2000) menar att individer samtidigt både förhandlar och omförhandlar sin egen roll i relation till de sociala normerna. Genusidentiteten är alltså både frivillig och påtvingad. Den är frivillig utifrån tanken att individen faktiskt har en möjlighet att påverka vem hen vill vara. Den är påtvingad utifrån att individen ständigt måste förhålla sig till, och anpassa sig efter genusstrukturerna i de institutioner, de sociala rum, som hen rör sig i. Connell beskriver processen av att våra sociala samspel påverkar vår syn av vad som är manligt/kvinnligt utifrån konceptet den reproduktiva arenan. Genus handlar i sådana fall om
den struktur av sociala relationer som fokuserar på den repro- duktiva arenan, och den uppsättning praktiker som drar in re- produktiva skillnader mellan kroppar i sociala processer. /.../ mer informellt handlar genus om hur samhället förhåller sig till män- niskokroppen och de många konsekvenser som det "förhållnings- sättet" får både i vårt privatliv och för mänsklighetens framtid. (2009, sid. 25)

Den definition av genus som jag använder mig av i denna studie bygger alltså på antagandet att genusstrukturer inte är konstanta, utan kan förändras beroende på kontext. Vad som i samhället anses vara kvinnligt respektive manligt kan skifta och förändras över tid. Det kan även finnas skillnader beroende på demografiska förhållande såsom kultur, etnicitet och klasstillhörighet (Connell, 2009, Kimmel, 2000). Connell beskriver det som att "vara man eller kvinna är alltså inget förutbestämt tillstånd. Det är ett blivande, ett tillstånd under aktiv konstruktion" (2009, sid. 18). Den syn på genus som informerat den här studien utgår från att vi människor skapar och omförhandlar vår genusidentitet $i$ samverkan med både andra individer (och deras genusidentitet) och de sociala rummens (exempelvis förskola, hem och arbetsplatser) genusstrukturer, eller som Kimmel beskriver det - "We are gendered people living in gendered societies." (2009, sid. 95). Forskning har visat att dessa sociala rum ofta både kan förstärka 
och reproducera stereotypa könsroller (Berner, 2003b; Kimmel, 2000).

\subsubsection{Teknikens historiska genusprägling}

Kopplingen mellan teknik och genus har existerat i åtminstone 500 år (Berner, 1999), men det är främst under den industriella delen av mänsklighetens historia som den vuxit sig stark, i synnerhet ur ett perspektiv där teknik tydligt har kopplats samman med maskulinitet på ett symboliskt plan (Mellström 1999; Faulkner, 2003). Den symboliska koppling mellan teknik och manlighet slog ytterligare rot i människors medvetande under förra sekelskiftet när ingenjören tog plats som en manlig förebild:

dyrkan av teknikens manliga hjältar som uppstod i många länder kring sekelskiftet och under tidigt 1900-tal. Statyer restes över uppfinnare och vetenskapsmän, Jules Vernes böcker om tekniska stordåd nådde miljonupplagor och drömmen för allt fler unga män var att bli ingenjör. (Berner, 1999, sid. 156-157)

Denna hjältedyrkan av den manlige teknikern verkar sedan ha fortlevt under 1900-talet. Ett tydligt exempel på detta är den "hackerkultur" som växte fram i samband med datorns frammarsch, där "hackern" ofta målats upp som en hjälte i allmänhetens ögon, och inte bara inom den egna subkulturen (Nissen, 2003).

I denna studie har jag utgått från att den samhälleliga bilden av genus och teknik sker i samproduktion. Precis som med genus så är även synen på teknik avhängig på kultur, tid, plats, organisation, etcetera. En förändring av ett samhälles syn på teknik är nära kopplad till bland annat ideologier, resurser, politiska system och/eller traditioner. Teknik är därmed inte frikopplat från sitt sociala sammanhang utan påverkas av intressenter och deras olika agendor - det vill säga alla människor, grupper och organisationer som har någon slags insats i tekniken (Berner, 1999). Eftersom relationen mellan genus och teknik är kulturellt och historiskt konstruerad betyder det att den kan utmanas och i slutändan omskapas, detta är dock något som tar tid och kräver ansträngning (Berner, 2003c; Faulkner, 2001, 2003; Mellström, 1999; 2003). Enligt Berner (1999) beror detta delvis på den själv- 
reproducerande cirkel som existerar mellan manlighet och teknik. Resonemanget bygger på att det är de som har makt och pengar i ett samhälle som kan utöva ett stort inflytande på hur tekniken gestaltar sig. Historiskt sett har det ofta varit män som haft kontroll över makt och kapital. Män har haft övervägande del toppositioner inom näringslivet och visat en tydlig tendens att gynna sådana som liknar dem själva (Berner, 2003c). Det är männen som varit företagsledare och ansvariga för forskningsinstitutioner där mycket av tekniken utvecklats (Connell, 2009). Berner (2003c) menar att teknik helt enkelt har utvecklats av män, för män. På grund av detta har det också historiskt sett varit män som intresserat sig för teknik, utbildat sig för att jobba med teknik och kunnat avancera (med stöd från andra män) inom yrken som utvecklat teknik, och i slutändan intagit rollen som skapare av ny teknik - cirkeln är därmed sluten. Enligt Berner kan teknisk utveckling naturligtvis inte enbart tillskrivas "mäktiga politikers eller kapitalägares krav" (1999, sid. 35) utan även praktikergemenskaper är en viktig faktor. Praktikergemenskaper är en sammanslutning av individer och institutioner, exempelvis forskare eller ingenjörer. Men även i detta fall blir resonemanget ovan detsamma. Den största delen av forskningen och teknikutvecklingen har historiskt sett dominerats och styrts av män och fortsätter att göras så även idag (Berner, 1999; Connel, 2009; Salminen-Karlsson, 2003).

Min utgångspunkt i studien har alltså varit att teknik har varit en manlig domän där klassiskt "manliga" egenskaper som rationalitet, objektivitet och abstrakt tänkande har premierats framför klassiskt "kvinnliga" egenskaper, vilka ansetts alltför emotionella och subjektiva (Berner, 1999). Denna koppling mellan teknik och manlighet har påverkat vad som från samhällets sida har definierats som just teknik.

Berner (2003e) beskriver att samhälleliga och kulturella genusstrukturer dikterar vad som ska uppfattas som den rätta tekniken eller den rätte teknikern. I dessa definitioner ingår ofta traditionellt sett "manliga" sysslor och yrken medan "kvinnliga" sysslor och yrken sällan ses som just tekniska. Ett exempel är personal i sjukvården som dagligen använder komplexa tekniska apparater, 
men vars yrke och kompetenser sällan ses utifrån att de arbetar med teknik (Berner, 2003a; Nyberg 2003). Teknisk kompetens rörande manligt kodad teknik och yrken har traditionellt sett gett makt medan teknisk kompetens i den kvinnliga domänen ofta betraktats på ett annorlunda sätt. Även om denna kunskap kanske har betraktats som en slags kompetens har den ytterst sällan setts som just teknisk kompetens från allmänhetens sida (Berner, 2003a). Nyberg (2003) förklarar att tekniska förbättringar gjorda av kvinnor inom exempelvis textil- och konserveringsindustrin inte har beskrivits som tekniska förbättringar medan manliga innovationer inom jordbruks- och vapenindustrin helt tydligt målats upp som just detta.

\begin{abstract}
Varför ses vanligen stål som mer tekniskt än tyg, nitförband som mer tekniskt än over-lock-sömmar och stålnitar som mer tekniska än sytråd? Förklaringen brukar baseras på att stål uppfattas som manligt, och därmed tekniskt, medan tyg uppfattas som kvinnligt, och därmed icke-tekniskt. Hade sömnad ansetts vara teknik hade nog våra tekniska högskolor haft kurser i ritteknik som även omfattade mönsterkonstruktion, kurser i materialteknik som även omfattade textila material och kurser i hållfasthetslära med räkneexempel gällande sömmars tålighet för belastning. (sid. 212)
\end{abstract}

Kimmel (2000) menar att stora delar av samhällets maskulinitets- och femininitetsnormer kan spåras tillbaka till industrialiseringens uppdelning av det dagliga livet/arbetet i den privata och den offentliga sfären. I denna uppdelning blev hemmet den kvinnliga domänen och den offentliga sfären blev den manliga domänen. I struktureringen av arbetsliv och familjeliv blev det mannens roll att yrkesarbeta och kvinnans roll att ta hand om hem och barn. Före industrialiseringen var inte denna uppdelning lika uppenbar, utan både män och kvinnor jobbade i eller kring sina bostäder - det var familjens behov som styrde arbetet. I och med den industriella revolutionen förflyttades mycket av männens del av hemarbetet, såsom läder- och/eller spannmålsbearbetning, från hemmen till fabrikerna och det blev istället fabriksägarna som styrde arbetet med hjälp av urverk och elektriskt ljus (Kimmel, 2000; Sundin, 2006). Industrialiseringens uppdelning i den yrkesarbetande mannen och kvinnan som tog hand om hemmet begränsade kvinnors ekonomiska och sociala infly- 
tande (Kimmel, 2000). I industrisektorns framväxt under efterkrigstiden gavs jobben en tydlig mansprägling och det var enbart genom att vara just en man som det fanns möjlighet att göra karriär, antingen i form av en chefsposition eller i form av utbildning och anställning som teknisk specialist. För kvinnor var detta hierarkiska avancemang nästintill omöjligt (Berner, 2003d).

Denna historiska uppdelning lever kvar än idag i form av att mansdominerade yrken ofta är strukturerade utefter en tydlig hierarki där männens tekniska kompetenser ses som inlärda och tas för givet. Motsvarande kompetenser hos kvinnorna testas och ifrågasätts däremot på olika sätt (Berner, 1999; 2003c). Liknande processer verkar vara verksamma även inom teknisk utbildning. Salminen-Karlsson (2003) menar att anledningen till varför reformer för att skapa en mer medveten ingenjörsutbildning som tar hänsyn till kvinnliga intressen sällan lyckas, går att spåra till den allmänt rådande bilden av kvinnan som mindre teknisk än mannen. Att skapa en sådan utbildning skulle helt enkelt göra att utbildningens status sjunker. På det här sättet utsätts kvinnor för motstridig information i form av vad som brukar kallas the double bind. De förväntas bryta mot könsstereotyper och ta sig in på välbetalda traditionellt sett manliga yrkesområden, men när de väl lyckats med detta har de stora svårigheter att göra avancemang - de slår helt enkelt i glastaket. Det går alltså att konstatera att kvinnor har sämre chans till befordran, får jobba med mindre kvalificerade uppgifter än vad de har utbildning till och dessutom får sämre betalt (Kimmel, 2000).

\subsubsection{Teknik och manlighet}

För att definiera genus använde jag mig i 3.1.1 av Kimmel (2000) och Connell (2009), men de har inte i sin forskning specifikt fokuserat på kopplingen mellan teknik och genus, även om de naturligtvis vidrör det på olika sätt. Eftersom kontexten av min studie är förskolan, det vill säga en arena som påverkar både pedagogers och barns vardagsliv, behöver jag förklaringsmodeller som dyker mer på djupet gällande hur just reproduktionen av genus och teknik sker i vardagslivet. Som jag har beskrivit i kapitel 3.1.2 ha jag även i studien utgått från att denna reproduktion i synnerhet handlat om mäns relation till den "riktiga" tekniken, 
och där både kvinnors relation till denna teknik och den "kvinnliga" tekniken marginaliserats. För att förklara hur denna reproduktion sker i vardagen kommer jag att använda mig av Wendy Faulkners (2001, 2003) forskning. Faulkner har definierat ett antal olika aspekter som beskriver hur teknik i allmänhet kopplas samman med manlighet i den samhälleliga diskursen. Faulkner (2003) benämner dessa som - centrala specialister, könsidentitet, arbetsfördelning, kulturella bilder, artefakter, samt den tekniska kunskapen, dess praktik och hur arbetet utförs.

\section{Centrala specialister}

En del av teknikens genusprägling kan beskrivas utifrån begreppet centrala specialister. Teknikens centrala specialister är de individer som har inflytande över utveckling och konstruktion av tekniska system och artefakter. Ur ett historiskt perspektiv har detta mestadels varit män (Berner, 2003c; Faulkner 2001, 2003). Nissen har exempelvis studerat hackerkulturen och visar på den roll som centrala specialister hade för utvecklandet av dator- och tv-spel, och hur detta kan kopplas till manlighet.

Datorerna utvecklades av manliga forskare på tekniska högskolor, de manliga studenterna lärde sig snabbt att använda dem och förde ut dem i samhället. De manliga forskarna startade tillsammans med sina studenter de första datorföretagen i nära anslutning till mansdominerade tekniska högskolor. De första datorspelen utvecklades av män. Arkadspelen var placerade i traditionellt manliga domäner. Spelkonsoller till tv-apparater, som var nästa generation av datorspel, kom i sin tur att förknippas med arkadspelen och därmed med män. /.../ Kort sagt konstruerades datortekniken av män för män. (2003, sid. 85 - 86)

Salminen-Karlsson undersökte civilingenjörsutbildningarna och pekar på en liknande mansdominans som Nissen. Studenterna på dessa utbildningar

har en viktig roll i formandet av framtiden i ett teknikberoende samhälle. Dessa studenter har av tradition varit och är fortfarande mest män, och utbildningen har utvecklats utifrån männens behov och preferenser. (2003, sid. 145)

Berner (2003c) menar att på grund av sina specialkunskaper så innehar ofta tekniska specialister maktpositioner inom olika in- 
stanser i samhället. Mycket av makten i svensk ekonomi har exempelvis gått att finna inom mansdominerade ingenjörsfält energidistribution, telekommunikation, och så vidare. Det är alltså en övervikt av män som innehar viktiga samhälleliga positioner, vilka kommer med en möjlighet att påverka teknikutvecklingen.

\section{Könsdentitet}

Faulkner (2001, 2003) förklarar att teknik utgör en viktig del i identitetsskapandet för män som arbetar med och/eller har teknik som hobby. Mellström (2003) menar att teknisk kompetens är en del av den manliga identiteten där tekniskt kunnande och ett praktiskt handlag är essentiella delar av att vara man, och där bilden av den tekniskt kompetenta mannen àtföljs av bilden av den tekniskt inkompetenta kvinnan. Både Wajcman (1991) och Nissen (2003) faller in i detta resonemang och menar att det historiskt sett funnits en tydlig koppling mellan maskulinitet och teknik inom industrisektorn, där de viktiga komponenterna för teknisk kompetens handlat om skicklighet i förhållande till mekanik.

\section{Arbetsfördelning}

Faulkner (2003) beskriver att den könsmässiga arbetsfördelningen kan ses som en av teknikens genuspräglingar. Berner (1999) pekar på att det inom tekniska företag råder en tydlig köns- och västvärldshierarki där "den vita manliga kompetensen anses per definition överlägsen kvinnors och invandrares, värd mer makt och belöningar" (sid. 86). Detta trots att många kvinnor generellt sett är överkvalificerade för det yrkesarbete de utför (SOU 2005:66). En aspekt av problemet är naturligtvis återigen frågan om vad som räknas som teknik från samhällets sida. Berner (2003c) beskriver ingenjörsyrket och hur det är format runt dikotomier. En ingenjör jobbar med "hårda" (läs manliga) värden, som abstrakt tänkande och objektivitet inte med "mjuka" värden, som helhetssyn och känslomässig reflektion. "Riktiga" ingenjörer jobbar med stora vapen- och energisystem, inte med småskalig vardagsnära teknik som symaskiner och preventivmedel. Tittar vi på hur det ser ut i arbetslivet i stort finns det en överrepresentation av män i de yrken som är uppbyggda runt 
maskiner, som fordonssektorn, bygg- och anläggning, etcetera (Berner, 2003d; Connell, 2009). Kvinnor är däremot överrepresenterade i yrken som traditionellt sett ansetts som icke-tekniska (Connell, 2009; SOU 2005:66). Dessa yrken återfinns ofta inom välfärdssektorn och handlar om vård, omsorg och utbildning (Berner, 2003d).

\section{Kulturella bilder}

Faulkner (2001, 2003) menar att en av teknikens könskodningar utgår från kulturella bilder. Bilden av teknik är hierarkisk där "männens" teknik, den "hårda" tekniken, har högre status än den "kvinnliga", "mjuka" tekniken (Berner, 2003a). Det handlar alltså om vad för slags teknik som anses vara just teknik i allmänhetens medvetande eller vem som får personifiera den typiske teknikern.

När det kommer till vad för slags teknik så går det att konstatera att de vanligaste bilderna av teknik hos gemene person oftast verkar hänga samman med manlighet, eller som Nissen (2003) uttrycker det

Det betyder att tankarna, när man talar om teknik, först går till sådan teknik som män vanligen ansvarar för som bilen, verktygsmaskinen eller datorn. (sid. 77)

En symaskin ses däremot sällan som teknik. Nyberg (2003) beskriver att när den tekniske vetenskapsmannen eller briljante uppfinnaren beskrivs i litteraturen och populärlitteraturen så är detta nästan alltid en man. (Några exempel på detta skulle kunna vara Oppfinnar-Jocke, Skalman, Doc Brown och Tony Stark Iron Man.)

\section{Artefakter}

En artefakt brukar generellt beskrivas utifrån att det är ett av människan tillverkat föremål som fungerar som en praktisk förlängning av kroppens förmågor (se exempelvis Bjurulf, 2011 eller Säljö, 2008). Faulkner (2001) menar att tekniska artefakter kan vara könskodade i sig, och att detta kan ske både på ett materiellt och/eller på ett symboliskt plan. Det första handlar om att artefakter både kan skapa och förstärka genusstrukturer, medan det 
andra handlar om att artefakter kan förknippas med manlighet eller kvinnlighet.

It is useful to distinguish between gender in technology and gender of technology. In the former case, gender relations are both embodied in and constructed or reinforced by artifacts to yield a very material form of the mutual shaping of gender and technology. In the latter, the gendering of artifacts is more by association than by material embodiment. (sid. 83)

Gender of technology, det symboliska planet, kan dels handla om hur språket används för att benämna olika delar av en artefakt eller ett tekniskt system, som exempelvis elektrikerns sätt att benämna delar som hona och hane. Det kan även handla om att många av vardagens artefakter har en lång tradition av att vara sammankopplade till vardagssysslor utförda av antingen män eller kvinnor. Traditionellt sett har många av hemmets artefakter inte använts i lika stor utsträckning av båda könen. Gender in technology, eller det materiella planet, handlar istället om att olika artefakters egenskaper kan designas med en kvinnlig eller manlig användare i åtanke. Dessa artefakters egenskaper kan både återspegla och konservera rådande genusstereotyper (Faulkner, 2001; 2003). Exempel på detta skulle kunna vara hur rakhyvlar designas olika beroende på om de marknadsförs mot en kvinnlig eller manlig användare.

Genuspräglingen av den tekniska kunskapen, dess praktik och hur arbetet utförs

Faulkner (2001, 2003) ser också den tekniska kunskapen i sig, och den praktiska tillämpningen av denna, som könad. Berner och Nyborg (2004) påpekar att, även om det aldrig går att säga att alla kvinnor eller alla män går att finna inom samma kultur eller sub-kultur, så finns det allmänna tankar i samhället om synen på teknisk kunskap och hur teknik utövas. Detta är tankar som

stämt mer eller mindre väl överens med de bilder av kvinnors och mäns egenskaper som dominerat i samhället och även i forskarsamhället vid olika tider och platser. Likaså kan man finna stilar för hur vetenskap och teknik utförs eller anses bör utföras, som präglats av verksamheternas historia och - kan man hävda - 
mansdominans. De ger regler för vem som räknas som en "riktig" forskare eller teknikexpert, för hur man skall bete sig för att passa in, för vilka språkbruk, interaktioner, klädstilar, värden och verksamheter som är önskvärda korrekta och lämpliga. Dessa regler har traditionellt utformats av män för män, och kan fungera utestängande för de kvinnor som närmar sig vetenskapen och teknikens världar, också idag. (sid. 35)

Faulkner (2001, 2003) menar att den tekniska kunskapens könskodning delvis går att spåra till naturvetenskapens framväxt och den dualistiska tanken om kropp och själ, handling och tanke. Faulkner $(2001,2003)$ lyfter att det blir intressant att ställa detta i relation till att det faktiskt inom olika maskuliniteter av teknik går att finna samma motsatspar, och att detta då istället diskuteras utifrån klassfrågor - exempelvis mellan den händige mekaren och den kalkylerande ingenjören (se även Mellström, 1999 och Wajcman, 1991). Wajcman (1991) beskriver att bilden av den tekniska kunskapen, kompetensen och färdigheten tydligt kopplar samman med egenskaper som kalkylerande rationalitet och objektivitet, egenskaper som historiskt sett tillskrivits män. Ett synsätt som innehas av många människor i samhället i stort är synen på kvinnan som känslomässig och subjektiv, och mannen som rationell och objektiv (Berner, 1999; Faulkner, 2001, 2003).

Faulkner (2001, 2003) menar att en orsak till att många flickor och kvinnor inte väljer en karriär inom teknik hänger samman med den allmänna bilden av teknik som något som tillhör den manliga sfären. Faulkner (2001) fortsätter dock med att påpeka att det till syvende och sist naturligtvis finns många individer som faller utanför ramarna för dessa stereotypa bilder av teknisk kunskap.

Of course, many of the ways of thinking and doing, which we stereotypically deem feminine, are useful if not essential in technical work: linguistic abilities in computer programming, for instance. And plenty of women now do jobs that are extremely technical, just as plenty of men are technically incompetent. In short, there are huge mismatches between the image and practice of technology with respect to gender. This crucial point is often missed. (2001, sid. 86)

Det är alltså viktigt att tänka på att när det talas om teknikens 
genusprägling är detta de breda dragen, de övergripande strukturerna, det behöver inte stämma på en individnivå.

\subsection{Förändring och identitet}

Ett centralt begrepp för denna licentiatavhandling har varit begreppet förändring. Begreppet har använts för att belysa hur deltagarnas syn på de tekniska aktiviteterna förändrades genom den aktionsforskningsprocess som pågick under drygt ett år. Det har handlat om att försöka utröna vilken roll personliga erfarenheter, professionella erfarenheter, genomförande av aktioner, möjlighet till diskussion och reflektion har spelat $\mathrm{i}$ denna förändring. I detta avseende blir det därför viktigt att definiera begreppet förändring, eller i alla fall beskriva vilka förutsättningar som är viktiga för att förändring ska kunna ske och hur detta ska relateras till denna studies kontext.

För att belysa förändringen har transformativt lärande använts. Transformativt lärande, eller transformative learning, är en teori för lärande hos vuxna och beskrevs första gången 1978 av Jack Mezirow. Utgångspunkten för utvecklandet av teorin går att spåra tillbaka till 1960- och 70-talets women's liberation movement och handlar om att en individs förståelse av dolda (makt)strukturer är väsentligt för frigörelse och egenmakt (Illeris, 2014a). Mezirow $(1997,2003)$ menar att människor överlag har svårt att ta till sig tankar och idéer som inte faller inom deras förutfattade meningar av saker och ting, och beskriver att transformativt lärande är en process där individen förändrar sina frames of reference genom att kritiskt granska och reflektera över sina förgivettagna antaganden. Detta sker dels genom självreflektion, dels genom att antaganden belyses i dialog med andra, och dels genom att implementera nya insikter i sin praktik (Mezirow, 1997; Illeris, 2014b).

Uttrycket frames of reference syftar till de olika upplevelser och erfarenheter en individ bär med sig, bland annat i form av värderingar, föreställningar och känslor, vilka tillsammans formar individens definition av världen och hens plats i denna. Dessa frames of references kan förändras (transformeras) genom att individen kritiskt granskar vilka antaganden som gömmer sig 
bakom dem. Men för att kunna göra denna förändring så är det av yttersta vikt att individen på något sätt belyser och blir medveten om sina antaganden, och därigenom får möjlighet att kritiskt granska dessa. Ett sätt att göra detta är genom deltagande i ett aktionsforskningsprojekt (Mezirow, 1997).

Mezirows perspektiv på transformativt lärande har blivit kritiserat för att endast fokusera på kognitiva aspekter och att inte tydligt lyfta fram emotionella och sociala aspekter, detta är även en kritik som erkänts av Mezirow själv (se bland annat Dirkx \& Mezirow, 2006 och Illeris, 2014a, samt Illeris, 2014b). Dirkx (i Dirkx \& Mezirow, 2006) har lyft in begreppet soul i transformativt lärande för att visa på att det inte enbart är individens medvetna förståelse som är avgörande för att förändra frames of reference, de omedvetna och djupare mentala processerna spelar också en viktig roll (Illeris, 2014a). Dirkx (i Dirkx \& Mezirow, 2006) menar att transformativt lärande utgår från upplevelser som är personligt meningsfulla och starkt känslomässiga, och att dessa upplevelser fördjupar individens förståelse av sig själv och sin relation till andra.

Illeris (2014a, 2014b), som menar att Mezirow lägger för stor vikt vid de kognitiva aspekterna av transformativt lärande och att Dirkx i sin tur lägger för stor vikt vid de emotionella och omedvetna delarna, har istället lyft fram ett perspektiv som är tänkt att på ett balanserat sätt inkludera de två andra perspektiven. Illeris (2014b) påtalar att det transformativa lärandet bör ses utifrån generella teorier om lärande och att det i sådana fall kan kopplas till begreppet transformative accomodation. Illeris (2014b) gör skillnad på vanlig accomodation och transformative accomodation, där den förra handlar om att individen förstår något på ett nytt sätt, medan den senare handlar om att individen förändrar sin utgångspunkt och sätt att agera $\mathrm{i}$ vissa scenarier. Illeris (2014a) menar därför att det transformativa lärandets huvudområde bör handla om identitet. Illeris (2014a) definierar identitet som ett psykosocialt koncept där det är sambandet och interaktionen mellan individen och den omgivande sociala miljön, och hur detta påverkar utvecklingen hos individen, som står i centrum. Illeris (2014a) menar att begreppet identitet löser kritiken 
med att transformativt lärande inte i tillräcklig grad tar hänsyn till de emotionella och sociala aspekterna hos individen, samtidigt som det även löser problemet med att det inte funnits ett tydligt huvudområde kring vad begreppet transformativt lärande har fokuserat på.

\begin{abstract}
By referring to the concept of identity in relation to transformative learning, the very definition will comprise a criterion of importance concerning changes that can be considered transformations because the concept of identity obviously only includes matters of a certain importance in relation to the mental totality of the individual. In this way, a boundary is set for the previously mentioned tendency to disseminate the concept of transformative learning to include all of the endless minor and major changes that constantly take place in the modern society (sid. 153)
\end{abstract}

På detta sätt särskiljs det transformativa lärandet till att inte enbart handla om mindre vardagliga förändringar och lärande som sker hos en individ, utan att även handla om mer genomgående förändringar på en högre kvalitativ nivå (Illeris, 2014b). Illeris (2014b) menar därför att transformativt lärande bör omdefinieras till "changes in the learner's identity" (sid. 573).

Illeris (2014a) beskriver begreppet identitet utifrån core identity, personality layer och preference layer.

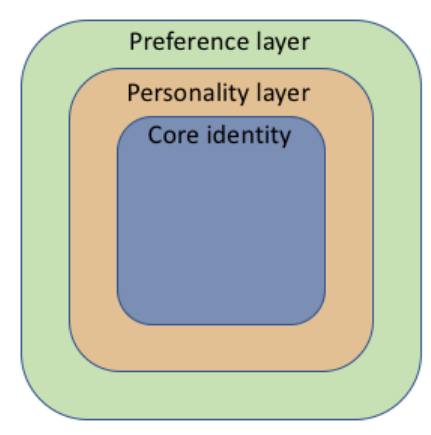

Core identity avser i det här fallet kärnan av en individs förståelse av sig själv. Denna förståelse utvecklas under individens uppväxt utifrån erfarenheter i förhållande till bland annat genus, relationer till närstående, begär, sätt att uppträda, etcetera. Denna core 
identity är i slutet av ungdomsåren relativt stabil och individer tenderar att under resten av livet försöka bevara den intakt. Men eftersom världen och det omgivande samhället är i ständig förändring, en förändring som idag går allt snabbare, så är det sannolikt att individer kommer att behöva ompröva och förändra sin core identity (Illeris, 2014a; Illeris, 2014b). Detta är även något som Mezirow (1997) har uppmärksammat i förhållande till den framtida medborgarens roll, exempelvis när det gäller att anpassa sig till en skiftande arbetsmarknad eller ta väl avvägda beslut i förhållande till komplexa tekniska system.

Om Core identity kan sägas fokusera på hur en individ förhåller sig till sig själv så handlar personality layer om hur individen förhåller sig till andra individer, grupper eller till samhället i stort, samt till viktiga frågor och händelser. Även här spelar dagens snabba förändring av vardagslivet, som påverkas av tekniska, politiska eller organisatoriska förändringar, en viktig roll. Illeris (2014a) menar att det är i detta lager av identiteten som det går att hitta en individs frames of reference. Om individen finner att det finns relevanta och goda orsaker att göra förändringar i denna del så kommer hen att göra det, men det görs inte lättvindigt.

Preference layer i sin tur beskriver saker som är angelägna och meningsfulla i individens vardagsliv, men som inte är av avgörande betydelse. I denna del av identiteten går det att hitta en individs vanemässiga agerande och beteende, samt det sätt på vilket hen uttrycker sig. Detta är handlingar som ofta sker per automatik och inte ges någon större reflektion. Förändringar i denna del sker inte utifrån samma slags övertygelse som förändringar i personality layer, de är inte lika avhängiga på tanke och känsla utan handlar mer om huruvida individen har energi och ork för att förändra sitt beteende och sitt agerande (Illeris, 2014a).

Den i huvudsak viktigaste faktorn för förändring som Illeris (2014a; 2014b) lyfter fram är motivation. Utan en stark vilja att transformera delar av sin identitet kommer inte en vuxen individ att göra detta. Den motiverande faktorn kan komma inifrån indi- 
viden själv, från omgivningen eller från båda dessa ställen. Det måste finnas en vilja hos individen att transformera sina frames of reference, motivation kan inte tvingas fram eller skapas från ingenting.

\subsection{Förskolans läroplan}

Förskolan har sedan dess första läroplan, Lpfö 98, haft framskrivna mål gällande det värdegrundsarbete som förväntas ske ute på de olika förskolorna i Sverige. Den värdegrund som beskrivs i Lpfö 98, och i dess efterkommande reviderade upplagor (Skolverket, 2010 och Skolverket, 2016), inbegriper bland annat frågor rörande jämställdhet (se exempelvis Dolk, 2013). Första gången begreppet jämställdhet dök upp i en svensk läroplan var i Läroplan för grundskolan 1969, Lgr 69. Begreppet skrevs fram för att orättvisor kopplade till könstillhörighet inte skulle försvinna bakom orättvisor kopplade till klasstillhörighet (Wernersson, 2009).

Jämställdhet finns med som ett tydligt framskrivet uppdrag i form av följande paragraf under del 1 i Lpfö 98 reviderad 2016 Förskolans värdegrund och uppdrag:
Vuxnas sätt att bemöta flickor och pojkar liksom de krav och förväntningar som ställs på dem bidrar till att forma flickors och pojkars uppfattning om vad som är kvinnligt och manligt. Förskolan ska motverka traditionella könsmönster och könsroller. Flickor och pojkar ska i förskolan ha samma möjligheter att pröva och utveckla förmågor och intressen utan begränsningar utifrån stereotypa könsroller. (2016, sid. 4)

Förskolan har alltså under en relativt lång tid haft tydligt framskrivna mål gällande sitt värdegrundasarbete med att motverka traditionella könsmönster och könsroller. Dessa traditionella mönster och roller anses begränsa individens handlingsutrymme och valmöjligheter. SCB (2014) anger att ett jämställt samhälle råder när 
kvinnor och män har samma makt att forma samhället och sina egna liv. Det förutsätter samma möjligheter, rättigheter och skyldigheter på livets alla områden. (sid. 2)

I stort sett samma definition går att finna i statens jämställdhetsutredning - Makt att forma samhället och sitt eget liv (SOU 2005:66). Det bör dock påpekas att även om denna definition av jämställdhet syftar till att lyfta kvinnors och mäns lika möjligheter gällande påverkan, rättigheter och skyldigheter så kan även detta perspektiv ses som en genusstruktur i sig i och med att det faktiskt är en definition som delar upp kvinnor och män i olika kategorier (Wernersson, 2009).

\subsection{Värdegrundsarbete och värdepedagogoik}

Studiens syfte har utgått från flickors och pojkars möjlighet att utveckla intresse och förmågor utan att bli begränsade av traditionella könsroller, något som kan kopplas till förskolan värdegrundsarbete. Thornberg (2004) beskriver att begreppet värdegrundsarbete fick sitt stora genombrott i och med skolans förändrade läroplaner (Lpo 94, Skolverket och Lpf 94, Skolverket) från 1994. Enligt Skolverket (2000) handlar värdegrundsarbetet om att förskolan (och skolan) har ett ansvar att förmedla och förankra grundläggande demokratiska värden, bland annat i form av människors lika värden och jämställdhet mellan män och kvinnor. Det handlar om pedagogernas förhållande till, och bemötande av, barnen med syfte att stärka de normer och värden som överensstämmer med läroplanens värdegrund. Thornberg (2004) menar att begreppet värdegrundsarbete är problematiskt eftersom det berör fasta normer och värden kopplade till politiska och moraliska utgångspunkter. Det har visat sig att pedagoger kan hämta normer och värden från sin egen livserfarenhet i sitt värdegrundsarbete som inte övernstämmer med de normer och värden som förmedlas i läroplanen. I Lpfö 98 reviderad 2016 beskrivs det att förskolans uppdrag är att ge lika möjligheter oberoende av kön, samt att det åligger förskolans personal att agera på ett sätt som inte förstärker stereotypa könsroller. Eidevald (2009) påpekar att vad detta innebär för verksamheten mer konkret är däremot inte beskrivit. Det är istället upp till verksamhet- 
en och dess pedagoger att tolka vad denna skrivelse innebär i just deras kontext, vilket har visat sig inte vara helt enkelt. Thornberg (2004) har föreslagit att begreppet värdepedagogik bör användas inom forskning istället för begreppet värdegrundsarbete och menar att

Värdepedagogik handlar om påverkan, mediering och lärande ifråga om moraliska eller politiska värden och normer. (sid. 103)

Thornberg (2004) fortsätter med att beskriva att medan begreppet värdegrundsarbete är sammanbundet med en skolpolitisk kontext så har värdepedagogik fördelen att det inte är knutet till en specifik värdegrund, utan kan istället användas för att beskriva allt arbete som på något sätt syftar till att påverka normer och värden i en lärandesituation, sak samma om det utgår från aktuella styrdokument eller ej. Det har även fördelan att även inbegripa den dolda läroplanen, det vill säga pedagogernas personliga värderingar, förväntningar och förhållningssätt.

\subsection{Tidigare forskning kopplat till teknik och genus i förskola och skola}

I följande delkapitel kommer jag dels att beskriva, för denna studie, relevant tidigare forskning gällande genus i förskolan. Jag kommer även att belysa relevant teknikdidaktisk forskning som utgått från ett genusperspektiv. Eftersom det finns sparsamt med forskning inom området teknik och genus i förskolan kommer jag även att använda tidigare forskning som fokuserat på genus och teknik i ett skolsammanhang. Hallström, Elvstrand och Hellberg, (2014) konstaterar att forskning gällande teknik i förskolan, sak samma om den intar ett genusperspektiv eller ej, lyser med sin frånvaro (se även Axell, 2012 och Sundqvist, Nilsson \& Gustafsson, 2015). När det gäller teknik i ett skolsammanhang så torde insikter kring teknik och genus kunna gå att relatera till förskolan då denna, som institution, inte befinner sig i ett vakuum utan ingår i en större samhällelig kontext, vilket medför att likheter med stor sannolikhet finns mellan de olika skolformerna när det gäller detta område. 


\subsubsection{Olika utgångspunkter i jämställdhetsarbetet}

Förskola och skola är två av de arenor på vilka barn och elever tillgodogör sig kunskaper och formar attityder till teknik (Berner, 2003b). Utifrån detta har förväntningarna på dessa instanser att bryta stereotypa könsmönster varit höga, det har dock visat sig att både förskola och skola löper risken att förstärka dessa könsmönster (Berner, 2003b; Salminen-Karlsson, 2003; SOU 2006:75). I förskolan sker formandet av könsmönster bland annat genom verksamhetens ramar och innehåll, genom personalens förhållningssätt, samt det material som finns tillgängligt för barnen (SOU 2006:75). Pedagogerna spelar en central roll för barnens förståelse av vad som av samhället anses vara lämpligt beteende för flickor respektive pojkar (Crisp \& Hiller, 2011; Oskamp, Kaufman \& Wolterbeek, 1996), vilket kan ske genom pedagogernas bemötande av barnen och hur de planerar aktiviteterna utifrån innehåll och material. Ärlemalm-Hagsér och Pramling Samuelsson (2009) menar att alla barn och alla pedagoger i förskolan är aktörer i formerandet av verksamhetens genusstrukturer och sammanfattar sina resultat med att förskolans vardag fungerar både bevarande och utmanande för rådande genusstrukturer.

Berner (2003b) menar att utbildningsväsendet ofta ses både som ett hinder och en lösning. Samtidigt som forskning har visat att barn och elever socialiseras in i roller i enlighet med samhällets stereotypa könsmönster så anses den också vara en effektiv arena för att utmana just dessa mönster. Frågan är dock hur bra skolan som institution verkligen är på att utmana och förändra individers föreställningar om genus. Exempelvis menar Kimmel (2000) att elever i skolan "könas" både genom den synliga läroplanen (styrdokument, läromedel, och så vidare.) och den dolda läroplanen (interaktionen med andra elever och lärare):

We learn, and teach one another, what it means to be men and women. And we see it all around us in our schools, who teaches us, what they teach us, how they teach us, and how the schools are organized as institutions. Schools are like old-fashioned factories, and what they produce is gendered individuals. Both in the official curriculum - textbooks and the like - and in the parallel "hidden curriculum" of our informal interactions with both teachers 
and other students, we become gendered. (sid. 149)

Kimmel (2000) menar dessutom att denna process hindrar alla barn, oavsett kön, att förbereda sig inför framtiden och hitta den väg som de vill vandra genom livet.

Gender inequality in education produces the gender differences we come to assume, with deleterious consequences for both genders; it impairs both boys' and girls' efforts to find their voices, dicipline their minds, and prepare themselves for their future. (sid. 171)

Den dolda läroplanen handlar även om förskollärarens/lärarens förväntningar på barnen och deras agerande i mötet med innehållet i förskolan/skolan.

Enligt Eidevald och Lenz Taguchi (2013) går det att se att jämställdhetsarbetet i förskolan idag ofta sker utifrån en könsneutral och/eller en kompensatorisk utgångspunkt. Det könsneutrala jämställdhetsarbetet vilar på tanken om att alla barn, oavsett deras könstillhörighet, ska behandlas lika och ges samma förutsättningar. Historiskt sett har det dock i detta arbete funnits en tanke om att det i synnerhet är flickorna som ska ges möjlighet till förändring, exempelvis genom att välja en utbildning eller yrke som har högre status (läs manligt kodade fält) än vad de traditionellt brukar välja (läs kvinnligt kodade fält) (Berner, 2003b; Eidevald \& Lenz Taguchi, 2013; Hedlin, 2009). Enligt Berner (2003b) har mycket forskning inom det teknikdidaktiska fältet utgått från synen att det är flickors och kvinnors förhållande till tekniken som är problemet. Fokus har varit att titta på skillnader mellan könen, där ansatserna ofta har handlat om det "otraditionella" valet och vikten av att förändra flickors attityd till teknik. Det som eftersträvats har varit en attitydförändring i en "positiv" riktning då flickorna, till skillnad från pojkar som förväntas ha vuxit upp med en nära relation till teknik, anses sakna tilltro till sin egen förmåga - de behöver helt enkelt stärka sitt tekniska självförtroende. Den centrala frågeställningen har varit i stil med - "vad måste göras för att få flickor att inse att de bör välja ett icketraditionellt (läs manligt) yrke?” (Berner, 2003b). 
Liknande sätt att se på flickorna som problemet går även att finna i de politiska dokument som beskriver hur den obligatoriska skolans första fyra läroplaner (Lgr 62, Lgr 69, Lgr 80 och Lpo 94) och teknikämnet i dessa arbetades fram (Hedlin, 2009). Det har ansetts viktigt för kvinnor att skaffa sig en utbildning inom det tekniska och/eller naturvetenskapliga fältet, eftersom de då kommer att kunna närma sig männen både vad det gäller lön och makt, ett argument som bland annat kan spåras till näringslivets syn på kvinnor som en outnyttjad begåvningsreserv (Berner, 2003b). Som ett tydligt exempel kan Lgr 8o lyftas fram. En av anledningarna till att teknik blev obligatoriskt innehåll för alla elever var att den dåvarande regeringen var oroliga för en naturvetarkris och ville att fler flickor skulle få ett intresse för teknik och naturvetenskap och söka sig till utbildningar inom detta fält (Lövheim, 2013).

Berner (2003b) menar att det i denna forskningsansats går att hitta en del av problematiken. Det är ofta flickornas förhållande till teknik som problematiseras, inte pojkarnas. Även om traditionellt sett manliga yrken, som exempelvis ingenjör och datatekniker, har målats upp som viktiga yrken att sträva efter för den framtida medborgaren, och medan det visserligen kanske är sant att dessa yrkeskårer är viktiga för framtidens kunskapssamhälle, är detta inte de enda yrkesgrupperna som är viktiga. Berner (2003d) menar dessutom att det inte med säkerhet går att säga vad för slags kunskaper de yrkesverksamma medborgarna i framtiden behöver besitta. Salminen-Karlsson (2003) menar att det är fruktlöst att diskutera problemet med att det finns för få kvinnor inom ingenjörsutbildningar i termer av rekryteringsfrågor och menar istället att det är viktigare att diskutera det utifrån ett rättviseperspektiv, där kvinnor och män har samma möjligheter att skaffa sig tekniska kunskaper och färdigheter. Berner (2003b) förklarar att forskning med fokus på det otraditionella valet ofta har utgått från att kvinnor/flickor inte aktivt förhandlar sin identitet i förhållande till rådande stereotyper. Grundförutsättningen har varit att flickor, utan invändning, inordnar sig i de roller, med tillhörande "kvinnliga" attribut, som är i samstämmighet med samhällets allmänna bild av vad det innebär att vara kvinna. Kimmel (2000) menar dock att det finns viss sanning i detta och 
hänvisar bland annat till att flickor generellt sett undervärderar sin förmåga när det gäller att studera matematik och naturvetenskap och att pojkar istället övervärderar sin förmåga.

Det kompensatoriska arbetet handlar istället om att pedagogerna utgår från att genus är en social konstruktion och att flickorna och pojkarna, bland annat utifrån samhällets förväntningar, har olika erfarenheter och därför olika beteende, kunskaper, etcetera. Det kompensatoriska arbetet utgår därför från en tanke om att behandla flickor och pojkar olika, där pojkarna ges möjlighet att träna traditionellt sett feminina egenskaper och vice vers. Ett sätt att göra detta har varit att skapa miljöer med olika slags genuspräglat material, där barnen kan stöta på både manligt kodat och kvinnligt kodat material (Eidevald \& Lenz Taguchi, 2013). Turja et al. (2009) menar att barnen i förskolan genomgår en process för att forma en stabil identitet, som ofta är i samstämmighet med normen i samhället, som flicka eller pojke. I detta identitetsskapande väljer barn ofta saker som är kodat till deras biologiska kön. Turja et al. (2009) menar att problemet är att forskning gällande teknik och yngre barn inte tar detta i beräkningen utan bara utgår från tanken att så länge flickorna får samma tillgång till det fysiska materialet (konstruktionsmaterial, verktyg, och så vidare) som pojkarna så kommer detta automatiskt att bidra till ett ökat intresse för teknik hos flickorna.

Den könsneutrala och den kompensatoriska utgångspunkten och deras respektive metoder för att arbeta med jämställdhet visar sig dock inte vara exklusiva utan kan existera sida vid sida hos pedagogerna, även inom ett och samma arbetslag (Edström, 2014; Eidevald \& Lenz Taguchi, 2013). Exempelvis kunde Eidevald (2009) konstatera att det hos förskollärare kan existerar flera olika synsätt på genus bredvid varandra, där vissa syns i tal medan andra syns i agerande, och att dessa inte alltid överensstämmer. Sak samma vilken utgångspunkt som använts så har det visat sig att de vanligaste målområdena för jämställdhetsarbetet på förskolan har varit språket och förändrade miljöer. Arbetet har handlat om att skapa miljöer med material som tilltalar både pojkar och flickor, samt att pedagogerna förändrat namnen på dessa 
miljöer och sett över hur de tilltalar barnen (Eidevald \& Lenz Taguchi, 2013).

\subsubsection{Pedagogens roll}

Eidevald (2009) undersökte på vilket sätt som förskollärare, genom sitt bemötande, gör skillnad på pojkar och flickor i vardagsrutiner och leksituationer, och kom bland annat fram till att förskollärarna i studien inte hade några svårigheter att diskutera jämställdhet i breda drag utifrån att alla barn, oavsett kön, ska ha samma möjligheter, exempelvis genom att de har samma tillgång till det material som används i lek och lärarledda aktiviteter (det könsneutrala perspektivet). Däremot verkade det vara svårare för förskollärarna att svara på direkta frågor om hur detta, mer konkret, kunde göras i verksamheten. Detta trots att förskolan i studien arbetade aktivt med jämställdhet. Eidevald (2009) ställer sig därför frågande till om det räcker med att i läroplanen skriva fram att det är de vuxnas förväntningar och bemötande som formar barnens uppfattning och att de vuxna har i uppdrag att ge barnen möjligheter att utveckla intressen utan begränsningar av stereotypa könsroller. Eidevald (2009) menar istället att uppdraget borde vara mer beskrivet i termer av hur detta ska göras för att skrivelsen ska få ordentlig genomslagskraft. Detta på grund av att formuleringar i jämställdhetsskrivelser ofta stannar vid problematiseringar av hur vuxna bemöter barn i form av tal, samt hur vuxna talar om sitt eget bemötande. Hur de vuxna faktiskt agerar sätts mera sällan under lupp. Eidevald (2009) kunde i sin studie även konstatera att förskollärarna hade enklare att lyfta fram hinder än möjligheter för deras jämställdhetsarbete. Dessa hinder inkluderade barnens föräldrar och massmedia. I synnerhet var det yttre attribut som kläder och leksaker som lyftes upp. Däremot problematiserade sällan förskollärarna sitt eget bemötande av barnen.

Månsson (2000) menar att i sitt möte med barnen är pedagogerna inte enbart påverkade av sina individuella upplevelser och erfarenheter utan även av samhälleliga diskurser gällande genus. Månsson (2000) påpekar att de genusstrukturer som går att finna på en förskola ofta kan kopplas samman med den "kvinnliga" världen, och att dessa strukturer $\mathrm{i}$ form av tillgängligt 
material eller verksamhetsplaneringar kan skicka signaler till barnen om vad som förväntas av dem beroende på om de är pojke eller flicka:

\begin{abstract}
Rummens inredning med dockvrå, men ingen verkstad, läshörna, men ingen snickarbänk har en symboliserande funktion och utgör en förutsättning för lekens villkor. I lekmiljön med sitt könsmärkta material, och i pedagogernas könskulturellt planerade verksamhet finns dolda förväntningar som signalerar vad flickor och pojkar förväntas leka. (sid. 204)
\end{abstract}

När en person växer upp i ett samhälle som omgärdas av genusstrukturer så informerar det personens hela tankesätt och ifrågasättanden om de egna förgivettagna antaganden kring genus blir hos många oreflekterat. Dessa antaganden kan sedan reflekteras i förskolans verksamhet i form av att:

olika mönster i pedagogernas kommunikation med flickorna och pojkarna representerar de handlingsmönster och traditioner som är en del av kulturen. (Månsson, 2000, sid. 205)

Enligt Eidevald (2009) är många människor, däribland förskollärare, ofta övertygade om att just de agerar jämställt. I sin studie kunde Eidevald (2009) se att förskollärarna utgick från resonemanget att de, i sin roll som pedagog, alltid bemötte barnen utifrån varje enskilt barns behov - det vill säga att de agerar jämställt i sin yrkesroll. Detta ligger i linje med vad som beskrivs i delbetänkandet av delegationen för jämställdhet i förskolan (SOU2004:115) som påpekar att det i förskolan ofta finns en uppfattning hos pedagogerna att de är könsneutrala och ser barnen som individer, oberoende av om de är pojkar eller flickor, och att de därför bemöter alla rättvist och likvärdigt. Det har visat sig att detta sedan sällan stämmer överens med pedagogernas agerande i verksamheten. Enligt Ärlemalm-Hagsér och Pramling Samuelsson (2009) kan detta bemötande bland annat bestå av ett så kallat särskiljande, där maskulinitet är överordnad femininitet i förskolans verksamhet. Det är pojkarnas varande och görande som befinner sig i fokus för pedagogernas blick. I aktiviteterna får inte flickorna samma utrymme och respons, detta sker bland annat genom att pedagogerna inte ser och uppmuntrar det flickorna gör. Pedagogernas bemötande av barnen kan också utgå från så 
kallad beständighet som handlar om att de utgår från stereotypa synsätt i sina förväntningar på vad som intresserar flickor respektive pojkar. Månsson (2000) undersökte interaktionen mellan pedagoger och barn i förskolan och menar att förskollärare ger pojkar och flickor olika möjlighet att uppfatta sig själva och förstå sin omgivning, där "pojkar fostras till individualister och flickorna till kollektivister" (sid. 197). Ärlemalm-Hagsér och Pramling Samuelsson (2009) konstaterar i sin studie att det var barnen själva som tog initiativ till att utmana rådande genusstrukturer och kunde inte hitta några exempel där pedagogerna själva utmanade barnen till gränsöverskridanden. Det visade sig att det var pedagogerna själva som i synnerhet agerade könstereotypt. Eidevald (2009) menar att det är problematiskt om pedgogerna utgår från stereotypa förväntningar på att pojkarna ska positionera sig främst, samtidigt som de även bemöts av pedagogerna där just deras vilja sätts i centrum, i synnerhet på bekostnad av andra barn. Detta synsätt kan återskapas både genom de vuxnas och barnens invanda handlingar och vanor, och riskera att sätta agendan för hur alla pojkar bemöts, inte enbart de pojkar som kan sägas uppfylla detta sätt att agera. På detta sätt kan tankar om skillnader mellan pojkar och flickor normaliseras, trots att det faktiskt är så att det finns både pojkar och flickor som positionerar sig främst, respektive är "försiktiga" i sin framtoning. Månsson (2000) kunde konstatera att det i synnerhet var i de lärarledda aktiviteterna som förskollärarna lyfte fram pojkarna framför flickorna genom att ge dem bekräftelse, uppmärksamhet och utrymme. Detta var inte lika synbart i de aktiviteter där förskollärarna inte hade en lika tydlig roll i form av vuxenledare. Å andra sidan menar Hallström et al. (2014) att om barn i förskolan lämnas helt fria i sitt utforskande av teknik, teknik som kan bestå av könskodade artefakter, finns en risk att förskolan som institution inte utmanar könstereotyper kopplade till teknik. Hallström et al. (2014) kunde i sin undersökning om hur barn i åldrarna 3-6 utforskar och lär teknik på förskolan se att barnen lämnas relativt ensamma i sitt utforskande av sin egen relation till teknik. Förskollärarna var sällan en aktiv del i detta, och i vid de tillfällen de var detta så var det sällan utifrån ett genusmedvetet perspektiv. 
Enligt Eidevald (2009) blir det svårt att försöka dra några slutsatser av förskollärares muntliga svar på frågan om de behandlar alla lika eller ej. För att förskollärarna ska kunna analysera sitt eget agerande och bemötande av barnen (och därmed förändra den egna verksamheten) räcker det inte enbart med kunskap om hur det ser ut på andra förskolor, vad studier säger och/eller tid för reflektion. Lösningen till problemet faller istället tillbaka på vikten av att förskolepersonalen får tid att belysa och reflektera över både verksamheten i sig, samt sitt eget agerande och bemötande av barnen (exempelvis genom att filma sig själva). Detta arbete bör ske utifrån förståelsen att individens roll som pedagog står i kontakt med rollen som en del av samhället i stort, eller som Eidevald (2009) uttrycker det:

\begin{abstract}
Arbete, familj och socialt umgänge konstitueras genom relationer på alla plan samtidigt och på detta sätt kan jämställdhet inte separera individ från samhälle, familj, arbete eller socialt umgänge. Det blir en del i allt det vi gör - och den privata sfären kan därför inte separeras från den offentliga. (sid. 184)
\end{abstract}

Utifrån detta resonemang blir det alltså viktigt att som pedagog inte enbart reflektera över och analysera sin egen roll i verksamheten, utan att även göra detsamma med sin roll/sina roller i den privata sfären, detta eftersom dessa med all sannolikhet har en påverkan på rollen som pedagog. Att belysa agerandet som pedagog utifrån personliga erfarenheter och upplevelser kan exempelvis vara en viktig roll i detta. Det fanns inget i Eidevalds (2009) studie som indikerade att förskollärarnas eget kön eller ålder spelade någon roll i hur de förhöll sig till barnen utifrån om barnen var flicka eller pojke. Inte heller fanns det några indikationer på att det fanns skillnader i bemötandet mellan förskollärare eller barnskötare. Eidevald (2009) förklarar detta dels med att genusstrukturer kring kön är starka i många samhällsgrupper och att detta sällan är något som belyses på utbildningar, sak samma vilken utbildningsnivå det handlar om, och dels att det är både män och kvinnor som återskapar dessa strukturer genom tal och handling. Sammanfattningsvis menar Eidevald (2009) att förskolan bör förstås utifrån att det är en verksamhet som inte är könsneutral, utan att det är en plats där reproduktion av kön ständigt pågår. 


\subsubsection{Pedagogen och tekniken}

I skolan har teknik och teknisk kunskap länge haft en framskriven roll, även om teknik som eget ämne inte infördes i den svenska grundskolan förrän mot slutet av 1900-talet (se exempelvis Hultén, 2013; Lövheim, 2013). När det gäller förskolan går det att notera att tekniska kunskapsområden var omnämnda redan i den första läroplanen, Lpfö 98 (Skolverket, 1998), men att begreppet teknik inte fanns tydligt utpekat. Lpfö 98 revideras första gången 2010 och en av de förändringar som gjordes var att teknik som kunskapsfält skrevs fram tydligare. Teknik är alltså ett relativt nytt ämnesinnehåll för pedagogerna i den svenska förskolan (Hallström et al., 2014).

Enligt Jarvis och Rennie (1998) så har lärare en mängd olika sätt att definiera vad teknik innebär. Några ser det som en allomfattande mänsklig aktivitet som handlar både om att designa och tillverka produkter, samt organisatorisk styrning, en del ser det som att konstruera i en klassrumsmiljö, medan andra ser det som tillämpad naturvetenskap (se även Stables, 1997). Detta är synsätt som även verkar existera bland förskollärare (Hallström et al., 2014; Sundqvist et al., 2015). Ett annat vanligt sätt att definiera teknik, både hos allmänheten och inom lärarprofessionen, är att likställa det med högteknologi (Jarvis \& Rennie, 1998; Siu \& Lam, 2005; Sundqvist et al., 2015). Det verkar också hos förskollärare finnas en tanke om att teknik kan definieras utifrån uppövad skicklighet (engelskans technique), exempelvis i form av att kunna hantera köksgeråd (Sundqvist et al., 2015). I slutändan är det dock ofta enskilda artefakter, i synnerhet artefakter kopplade till den manliga sfären av teknik, som får personifiera bilden av teknik för många förskollärare (Sundqvist et al., 2015). Sundqvist och Nilsson (2016) menar att förskollärare behöver bredda och fördjupa sin förståelse av vad teknik i förskolan kan innebära. Ett sätt att göra detta på kan vara att i grupp identifiera och reflektera över sina förgivettaganden gällande den egna praktiken, och därigenom komma fram till vad för slags tekniska aktiviteter som ska lyftas fram i verksamheten.

Det har visat sig att både vuxna och barn ofta har en god förståelse av vardags- och fritidsartefakter men att de däremot har 
svårt att överblicka de tekniska system som dessa är en del av (Mawson, 2010; 2013; Siu \& Lam, 2005). Berner (1999) beskriver att den politiska, sociala och ekonomiska sidan av tekniken, som faktiskt möjliggör dess existens, sällan är lika självklar. Jarvis \& Rennie (1998) menar att eftersom lärare har en varierande definition av teknik, så kommer de att ha problem att visa barn att "nu jobbar vi med teknik". På grund av detta går två möjligheter att utmana stereotypa uppfattningar till spillo. Dels får inte barnen möjlighet att skaffa sig positiva erfarenheter som kan komma att påverka framtida karriärvägar och dels utnyttjas inte möjligheten att problematisera vad teknik är (se även Stables, 1997; Trepanier-Street \& Romatovski, 1999). Turja et al. (2009) menar att om pedagoger utvecklar sin egen genusmedvetenhet gällande yrkes- och vardagsliv, och skaffar sig en större förståelse för vad teknik är, så kommer de både att kunna agera som goda förebilder för förskolebarnen och kunna utveckla verksamheten i en riktning som strävar efter att motverka stereotypa könsroller. Om läraren har en tydlig förståelse av vad teknik är så kommer detta att hjälpa barnen att identifiera teknikinnehållet i den dagliga verksamheten. (Jarvis \& Rennie, 1998). Viss forskning pekar på att en av de viktigaste faktorerna för att barnen i förskolan ska kunna utveckla sin förståelse av teknik är deltagande i aktiviteter med en aktiv pedagog (Mawson, 2013; Stables, 1997). Dessa aktiviteter spelar en viktig roll då de ger pedagogen en chans att hjälpa barnen att identifiera och analysera teknikens samhälleliga och miljömässiga påverkan. Detta är viktigt eftersom barnen inte har tillräckliga erfarenheter av den konstruerade världen för att kunna göra detta själva (Mawson, 2013). Men det kan även handla om att pedagogen behöver finnas på plats för att hjälpa barnen med mer konkreta aspekter, såsom hur olika material ska sammanfogas eller formas (Fleer, 2000).

Forskning pekar dock på att det inte räcker att förskollärarna är en aktiv del av den tekniska aktiviteten, det handlar även om hur de planerar den och agerar med barnen i den. MacNaughton (1997) undersökte exempelvis vilka olika strategier pedagoger använde sig av för att ge flickor samma tillgång till aktiviteter som involverade konstruktion med klossar som pojkar hade. I studien hade MacNaughton (1997) först kunnat se att pojkarna, 
och i synnerhet de pojkar som av pedagogerna benämndes som "macho", stängde ute flickorna från det utrymme som innehöll klossar. De strategier som användes för att komma runt detta problem handlade dels om att försöka öka flickornas intresse för materialet, vilket antingen gjordes genom att flytta in traditionellt sett kvinnligt kodat material bland klossarna (konstruktionshörnan), att föra samman konstruktionshörnan med "hemvrån”, eller att införa tider när bara flickorna hade åtkomst till konstruktionshörnan. Dels handlade strategierna om att pedagogerna var mer närvarande i konstruktionsleken för att se till att inte pojkarna tryckte undan flickorna. MacNaughton (1997) menar att det finns problem med båda dessa strategier där den tidigare utgår från en syn att det är flickornas inställning och intresse som är problemet medan den senare utgår från att det istället är pojkarna som är problemet. MacNaughton (1997) pekar på att flickornas återhållsamhet till att ge sig i kast med konstruktionsmaterialet bör förstås utifrån att det inte handlar om att de är ointresserade av materialet per se, utan att de är ointresserade av klossarna utifrån genusstrukturer där "macho"-beteendet är normen. Vägen framåt blir i detta fall istället att utmana barnens tankar om vad det innebär att vara kvinna/flicka respektive man/pojke i en samhällelig diskurs.

För att summera den tidigare forskningen så pekar genomgången i delkapitel 3.5 på att förskolan är en institution där, precis som i övriga samhället, stereotypa könsroller och könsmönster både reproduceras och utmanas. Mycket av forskningen pekar på att pedagogen har en viktig roll när det kommer till att utmana dessa stereotyper. Detta utmanande handlar både om bemötande av barnen och planerandet av aktiviteterna. För att ett sådant utmanande ska kunna ske är det dock av vikt att pedagogerna får möjlighet att reflektera, inte bara över aktiviteternas innehåll och material samt sitt eget bemötande av och förväntningar på barnen, utan även över sitt agerande och synsätt i den privata sfären. När det kommer till teknikdidaktik så kan denna reflektion handla om att pedagogerna behöver skapa en förståelse för hur normativa synsätt på teknik påverkar deras förväntningar på barnen och hur deras egen syn på teknik påverkar hur de förhåller sig till aktiviteterna i förskolan. Forskningsgenomgången vi- 


\section{Kapitel 3}

sar även på komplexiteten i att som pedagog försöka utmana stereotypa könsroller och könsmönster. 
Kapitel 4

\section{Metod}

I följande kapitel redogör jag först för studiens övergripande design. Efter detta presenterar jag hur datainsamlingen gått till och hur den har analyserats. Till sist beskriver jag aktionsforskningens specifika validitetsaspekter och de etiska överväganden som gjordes inför och under studien.

\subsection{Aktionsforskning}

Aktionsforskning har valts som metodologisk utgångspunkt för denna studie. I en aktionsforskningsstudie arbetar en eller flera forskare tätt tillsammans med en grupp människor från en organisation/verksamhet, med målet att lösa ett praktiskt problem eller ett dilemma som identifierats och artikulerats av dessa personer. Problemet ska alltså i idealfallet komma inifrån organisationen (Herr \& Anderson, 2005; Rönnerman, 2012a; Westlander, 2006). Enligt Rönnerman (2010) utgår aktionsforskning i skola och förskola från synen att det är pedagogen som har bäst insikt i sin praktik och därför är den som är bäst lämpad att peka ut vad som behöver förändras. Weiner (2005) menar att aktionsforskning både är ett sätt att utveckla yrkeskunskaper och ett sätt att förbättra praxis. Genom aktionsforskningen får människorna från organisationen, även kallade deltagarna, en djupare förståelse av organisationen samtidigt som de får kunskap för att kunna utveckla den dagliga verksamheten. I ett bredare perspektiv kan forskningen hjälpa till att förklara och belysa varför denna förändring sker och på detta sätt bidra till att förbättra den generella förståelsen av förändringsprocessen i sig (Rönnerman, 2012a; Weiner, 2005).

I mötet mellan deltagarna - vilka har en kollegial och praktisk erfarenhet av verksamheten, och forskaren - som bidrar med teoretiska perspektiv, teorier och andra kunskaper, kan ny förståelse av verksamheten nås. Denna nyvunna kunskap kan både användas för att utveckla verksamheten, men även fungera som verktyg för ny forskning (Rönnerman, 2010; 2012a). I detta möte mellan 
deltagarna och forskaren spelar handledning en central roll. Under denna făr deltagarna tillfälle att diskutera och analysera de aktioner som genomförts i verksamheten. Detta ger möjlighet att både synliggöra och reflektera över det identifierade problemet och på så sätt föra förändringsprocessen framåt (Rönnerman, 2010).

Enligt Herr och Anderson (2005) så kan aktionsforskning ta sig olika former och benämnas på en rad olika sätt. Dessutom kan både syfte och epistemologi variera beroende på forskningens sociala kontext. Oberoende av form och/eller namn så kan aktionsforskning beskrivas utifrån en gemensam grundstruktur. En aktionsforskningsstudie sker ofta i en kollaborativ inramning där det identifierade problemet bearbetas av deltagarna och forskaren i aktionsforskningsgruppen. Detta sker genom att belysa problemet med hjälp av både personliga erfarenheter och olika teoretiska perspektiv. Utifrån detta arbetar gruppen sedan fram aktioner som iscensätts i den dagliga verksamheten. Dessa aktioner utvärderas och analyseras tillsammans under efterföljande gruppträffar. Denna process kommer troligtvis att förändra deltagarnas förståelse av problemet och forskningsfrågan kommer därmed att behöva justeras utifrån denna nya insikt. Detta ger sedan upphov till att en ny aktion kan planeras och genomföras i verksamheten, vilket i sin tur ger nytt underlag för analys. Detta är en iterativ cykel som inom aktionsforskning kallas för planeraagera-observera-reflektera-spiralen (Herr \& Anderson, 2005). Rönnerman (2010) beskriver denna process på följande sätt:

De olika stegen brukar betecknas som en spiral av aktiviteter i termer av att planera - agera - observera - reflektera. Det handlar med andra ord om att utifrån en undran planera en aktivitet, följa den genom observationer av vad som händer, analysera den information som samlats in, samt att diskutera och reflektera över vad som skett. Analys och reflektion leder till nya frågor, som kräver nya aktioner, som i sin tur leder till reflektioner som genererar nya frågor ... och så vidare. Under hela processen pågår en utveckling och kritisk granskning av teorier och begrepp för det område som fokuserats. (sid. 13-14)

En av anledningarna till att aktionsforskning har valts som metodologisk utgångspunkt i denna studie handlar om att denna form 
av forskning har visat sig fruktbar när det handlar om att lärare ska analysera sig själva och sin egen undervisning. Andersson, Hussenius och Gustafsson (2009) drar, i sin forskning om genus och undervisning i naturvetenskap, slutsatsen att medverkan i ett aktionsforskningsprojekt hjälper lärare att tydliggöra och utmana sin egen genussyn. Genom detta skapas också ett tillfälle för lärarna att förändra sin pedagogik till att bli mer genusmedveten. Detta är i linje med Nylund et al. (2010) som menar att:

\begin{abstract}
Aktionsforskning, och det språk vi utvecklar genom den, ger oss verktyg att förstå många vardagliga och självklara situationer på ett nytt sätt. Vårt sätt att tänka om sådant vi varit med om förändras och vi ser nya möjligheter i till synes bagatellartade händelser. (sid.
\end{abstract} 11)

Deltagande i ett aktionsforskningsprojekt kan alltså ge deltagarna redskap för att belysa och analysera de förgivettagna antagande som kan ligga till grund för hur de agerar som pedagoger.

För att testa genomförbarheten hos en tänkt studie genomförs i många forskningsansatser en pilotstudie, vilket är en mindre omfattande och avgränsad version av den kommande studien (Robson, 2011). En pilotstudie i den klassiska bemärkelsen genomfördes inte inför denna undersökning, i aktionsforskning är det vanligt att "a pilot study is likely to simply be early cycles of research in an ongoing research spiral" (Herr \& Anderson, 2005, sid. 71). Däremot genomförde jag en liten "övningsstudie” på en av mina tidigare arbetsplatser. Syftet med denna var dels att jag skulle få en praktisk förståelse för hur ett aktionsforskningsprojekt kan fungera och dels att den skulle ge mig insyn i min roll som samtalsledare.

\title{
4.2 Aktioner
}

Arbetet i en aktionsforskningsgrupp sker genom en kollaborativ process där deltagarna och forskaren träffas för att diskutera aktuell litteratur och erfarenheter från de aktioner som genomförts i verksamheten (Rönnerman, 1998). Som beskrivits i föregående delkapitel är det de aktiviteter som genomförs i verksamheten som kan ses som aktioner, men även mötena i gruppen i sig går 
att se som aktioner. Varje möte i denna studie gav gruppen ny information om och förståelse av det identifierade problemet. Varje möte dokumenterades därför med hjälp av en videokamera och analyserades sedan av mig i förhållande till forskningsfrågorna för att staka ut vägen inför nästa möte. Det är dock viktigt att tänka på att ett kollegialt samtal i sig inte bidrar till professionell utveckling utan att det måste kompletteras med systematiskt insamlad empiri från den egna verksamheten (Björndahl, 2005; Rönnerman, 2012b). Denna empiri kan sedan användas i gruppens möten för att ställa olika perspektiv mot varandra (teorier, praktisk erfarenhet, värderingar, etcetera). På detta sätt kan den professionella kompetensen utmanas och utvecklas (Rönnerman, 2010). I den här studien är det först och främst de möten som gjordes i gruppen som har fungerat som det empiriska materialet och ställts under en noggrann analys, men det som hände under dessa möten påverkades ju naturligtvis till stor del av vad som hade observerats under de aktioner som skedde $\mathrm{i}$ verksamheten. I resten av texten kommer jag att skilja på dessa olika slags aktioner genom att använda benämningarna mötesaktioner och verksamhetsaktioner.

Som diskuterats tidigare spelar reflektion över både yrkesliv och privatliv en avgörande roll när det kommer till synen på teknik och genus. I arbetet med att utveckla tekniska aktiviteter i verksamheten som inte begränsar flickor och pojkar utifrån traditionella könsroller spelar därför gruppmedlemmarnas (jag inkluderad) analys av sitt eget liv och sin egen syn på ämnesstoffet, och hur detta återspeglas i verksamheten, en viktig roll. Rönnerman (2012b) påpekar att genom att lärare förstår sin egen lärandeprocess får de också förutsättningar att förändra lärandesituationen för barnen. Även detta pekar alltså på att gruppens möten kan ses som aktioner i sig. Genom de reflektioner och analyser som sker i diskussionerna (mötesaktionerna) kan nya insikter vinnas, som i sin tur kan vara till hjälp vid utvecklandet av de aktioner som ska genomföras i verksamheten (verksamhetsaktionerna). 


\subsection{Verktyg}

För insamlande av empiri i en aktionsforskningsstudie behövs något eller några slags verktyg. I det här fallet användes videoupptagning för att både dokumentera mötesaktionerna och verksamhetsaktionerna. Valet av videoupptagning som verktyg berodde på en rad olika orsaker. För det första gav det mig möjlighet att vara en deltagande och likvärdig part i gruppens diskussion. Detta hade inte varit möjligt om jag hade valt att föra anteckningar, jag är helt enkelt inte så pass snabb att jag hade fătt med allt intressant som skett. Dessutom finns det en risk att antecknandet hade stört gruppens naturliga dynamik. Björndahl (2005) menar att om deltagarna ser att deras utsagor antecknas så kan de börja väga sina ord och hålla sig från att säga vad de faktiskt tycker och tänker. Det finns också en risk att den som antecknar omedvetet ger mer utrymme åt de uttalanden som hen "vill" höra.

Videoupptagning, i förhållande till enbart ljudupptagning, har fördelen med att det i efterhand går att observera intressant information om de icke-verbala signaler som deltagare sänder ut under samtalet. Även om det finns en risk att videoupptagning kan hämma diskussionen i en forskningsgrupp har det visat sig att många, men inte alla, personer snabbt vänjer sig vid kamerans närvaro och glömmer bort att de faktiskt filmas (Björndahl, 2005). Detta var något som deltagarna själva påpekade vid ett flertal gånger. Ett utdrag från det första mötet kan användas för att exemplifiera detta.

Johan: Om det är så att ni känner att det är jobbigt att bli filmade så får vi ta upp det till diskussion inför kommande gånger också.

Anna: Nä, det spelar ingen roll. Bara vi slipper se det.

Sara: Precis.

Carina: Precis, bara vi slipper se det.

Lena: Jag tror vi glömmer det om en stund.

Eva: Ja, precis.

Andra studier pekar på att deltagare $\mathrm{i}$ en studie som videodokumenteras ofta är medvetna om att de blir filmade och dessutom, mer eller mindre, interagerar med videoupptagningsenheten (exempelvis med hjälp av blickar) 
(Norris et al., 2014). Pirini et al. (2014) menar att bara genom att vara på plats förändrar forskaren det som i annat fall hade kunnat vara en naturlig interaktion. Min egen studies första verksamhetsaktion är ett exempel på detta. En del av pedagogerna uttryckte att de inte agerade som de brukade göra på grund av att de ville se till att filmen blev så bra som möjligt, detta så att jag skulle ha ett bra material för analys. Det var först sex månader in i studien som de uttryckte att de började känna sig bekväma med videoupptagningsenheten.

Enligt Norris et al. (2014) så för data i form av inspelat videomaterial alltid med sig både etiska och praktiska frågeställningar som forskaren måste förhålla sig till, i synnerhet när det handlar om barn. Exempelvis kan en videoupptagningsenhet endast fånga det den fokuserar på, den kan dessutom inte fånga vissa andra sinnesupplevelser som exempelvis lukt. Det bör heller aldrig glömmas bort att det är forskaren som styr vart videoupptagningsenheten riktar sitt fokus och datamaterialet kan därför inte sägas vara helt objektivt (Norris et al., 2014).

I den iterativa processen är det även viktigt att, utifrån den gemensamma reflektionen av verksamhetsaktionerna, utröna vad som blir nästa steg. Om inte en videoupptagningsenhet hade använts, om jag istället exempelvis hade gjort deltagande observationer, hade det varit svårt att ge alla deltagare möjlighet att se vad som hände $i$ de andra deltagarnas verksamhetsaktioner. Till sist så ställde jag även frågan till deltagarna angående vilket slags verktyg de själva föredrog och de tyckte att videoupptagning var att föredra.

\subsection{Urval}

De två förskolor som ingick i studien är båda kommunala förskolor och bildar tillsammans en förskoleenhet. De är placerade i en förort i en medelstor kommun i södra Sverige, där många av barnen har svenska som förstaspråk. Att just dessa förskolor fick frågan om att delta i studien hängde samman med att jag visste att förskolorna sedan tidigare visat intresse av att arbeta med både genusrelaterade frågor och utveckling av teknikaktiviteter. 
Valet baserade sig både på att detta intresse kunde ge mig som forskare så bra tillgång till aktionsforskningsgruppen som möjligt (det vill säga att förskolecheferna prioriterade gruppens arbete), samt att det kunde öka möjligheterna att de förskollärare som valde att bli en del av gruppen såg studien som "sin egen", att de var en del av problemformuleringen. De lärare som ingick i studien valdes inte ut av mig eller förskolecheferna utan urvalsprocessen baserades helt på eget intresse. Efter att jag haft ett informationsmöte med alla förskollärarna på de två förskolorna var det fritt för de som ville bli en del av gruppen att anmäla sitt deltagande. Återigen var detta ett sätt att öka möjligheterna för att deltagarna såg studien som sin, se även 4.6 (Validitet) och 4.7.2 (Etiska överväganden i förhållande till deltagarna i studien och andra vuxna) för komplementerande information gällande urval.

\subsection{Analys}

De tretton mötesaktionerna resulterade i cirka 24 timmar inspelat videomaterial. Materialet transkriberades sedan utifrån att det skulle ställas under luppen för en tematisk analys (Braun \& Clarke, 2006; Attride-Stirling, 2001). Enligt Braun och Clarke (2006) kräver inte en tematisk analys en ordagrann transkription utan det som är viktigt är att transkriptionen innehåller den information som är väsentlig för själva analysen och att återgivningen av uttalanden överensstämmer med innehållet i vad som sades.

Braun och Clarke (2006) beskriver arbetsgången i en tematisk analys utifrån sex delsteg. Nedan kommer jag att beskriva dessa steg och även förklara hur dessa processer såg ut $\mathrm{i}$ det analysarbete jag gjorde utifrån transkriptionerna av mötesaktionerna.

1. Att bekanta sig med materialet - Detta är själva grundstommen för den tematiska analysen. Om forskaren har samlat in materialet genom att på något sätt själv varit medverkande kan det medföra att hen redan i detta skede påbörjat det analytiska arbetet. Om den data som samlats in är av verbal karaktär innebär det att den måste transkriberas, dessa transkriptioner måste därefter läsas upp- 
repade gånger. Transkriberingen handlar inte enbart om att sätta ord på papper utan under detta arbete fortsätter det analysarbete som startade under datainsamlingen. Själva transkriberingsarbetet gör att forskaren får en mer ingående förståelse av denna data (Braun \& Clarke, 2006)

Under denna studie var jag en medverkande part i insamlandet av det empiriska materialet. Vad det gäller mötesaktionerna deltog jag som en del av gruppen, men min roll var inte hela tiden densamma utan skiftade lite beroende på var i aktionsforskningsprocessen gruppen befann sig. Under vissa möten var jag mer styrande och hade en tydligare agenda med vad som skulle diskuteras medan jag under andra möten var mer tillbakadragen. Det som var avgörande för vilken roll jag intog var kopplat till var gruppen befann sig i nuvarande aktionsforskningscykel. Om vi exempelvis befann oss direkt efter en genomförd verksamhetsaktion var jag mer styrande i vad som skulle diskuteras eftersom jag då hade tittat igenom och analyserat intressanta skeenden, i förhållande till problemformuleringen, i det inspelade videomaterialet. Det var sedan dessa skeenden som användes för diskussion under mötesaktionerna i gruppen.

Det var även så att jag efter varje möte sammanfattade vad som sagts, en sammanfattning som mailades ut till deltagarna för member checking (Herr \& Anderson, 2005). Denna sammanfattning användes sedan som underlag för planering av kommande möte. Det går därmed att konstatera att jag redan under aktionsforskningsprocessen hade börjat att bekanta mig med det empiriska materialet. Vad det gäller själva transkriberingen av gruppens 13 mötesaktioner så startade jag detta arbete under studiens andra tredjedel, hösten 2015, och transkriberingen av det sista mötet avslutades under våren 2017. När alla möten var transkriberade började sedan arbetet med att läsa igenom transkriptionerna ett flertal gånger för att ännu tydligare lära känna materialet. 
2. Att sätta samman initiala koder - Utifrån de upprepade läsningarna bildar sig forskaren en idé om vilka intressanta aspekter som finns i datamaterialet. Utifrån detta sätts sedan koder samman (Braun \& Clarke, 2006). Koderna kan genereras både utifrån inneboende innebörder i texten, med hjälp av forskningsfrågans bakomliggande teorier eller med hjälp av båda dessa (Attride-Stirling, 2001). I detta arbetet kan ett uttalande kodas under flera olika teman (Braun \& Clarke, 2006).

För att koda transkriptioner brukar idag ofta datorprogram anpassade för just denna uppgift att användas. Detta var även något som jag till en början provade att använda, men jag upptäckte ganska fort att jag hade stora problem att få en tydlig överblick och struktur med hjälp av detta verktyg. Efter lite rådgörande med mina handledare valda jag att istället göra kodningen "old-school" - det vill säga att skriva ut alla transkriptioner, hacka sönder dem i olika uttalanden och meningsutbyten, och sedan, med hjälp av färg och text, ge dessa koder. Detta sätt att arbeta fungerade betydligt bättre för mig. Det bör tilläggas att de koder som jag fann i transkriptionerna och de teman som dessa resulterade $\mathrm{i}$ är avhängiga studiens frågeställningar och den förståelse i relation till dessa som jag hade med mig in i arbetet. Altrichter, Posch \& Somekh (2000) beskriver det som att "Categories (features) need to be chosen which are relevant to the research question and at the same time partially express the contents of the data" (sid. 124). Björndahl (2005) påpekar att analyserande är en subjektiv process där forskaren plockar ut faktorer av särskild vikt. Björndahl (2005) fortsätter med att beskriva att analys alltid innebär "att man väljer att fokusera på något och att man förbiser något annat. Man kan aldrig analysera allt i en situation" (sid. 118).

3. Att leta efter teman - När allt material har blivit kodat är nästa steg att utröna huruvida olika koder kan kombineras till olika slags teman. Vissa koder kan bilda övergripande teman medan andra bildar underteman, som i sin tur in- 
går i ett övergripande tema. Underteman kan hjälpa till med strukturen för stora och komplexa teman. Det kan även vara så att vissa koder inte faller inom ett tema (Attride-Stirling, 2001; Braun \& Clarke, 2006).

När hela materialet var sönderstyckat och hade fătt olika koder började jag att gå igenom dessa och bunta samman de uttalanden och meningsutbyten som verkade beskriva liknande saker. Det kodade materialet kom på detta vis att börja bilda olika slags teman. I detta skede av arbetet började jag även plocka bort delar av det empiriska materialet. Det kunde handla om både hela grupper av koder, som bildat teman, eller separata uttalanden och meningsutbyten. Anledningen till att de plockades bort var för att jag inte kunde se att de hade någon tydlig koppling till studiens forskningsfrågor. Efter detta letade jag efter kopplingar mellan de olika, för forskningsfrågorna relevanta, teman som hittats för att se om de kunde sättas samman till övergripande teman.

4. Att granska teman - I detta steg utsätts de identifierade temana från föregående steg för en genomgående granskning. I detta arbete är det troligt att en del teman försvinner, en del slås ihop och en del behöver delas upp ytterligare (Braun \& Clarke, 2006).

5. Att tydligt definiera och namnge teman - I det näst sista steget handlar det om att definiera och tydliggöra vad de identifierade temana handlar om. I detta arbete kan uttalanden från transkriptionerna användas, men det är viktigt att beskriva vad dessa säger om temat som helhet. I slutändan handlar det om att förklara varför just dessa teman är av särskild vikt och intresse. Här ska alltså de identifierade temana kopplas tillbaka till forskningsfrågorna. (Braun \& Clarke, 2006).

För min del så följde inte steg 4 och 5 på varandra utan skedde istället parallellt i och med att jag efter steg 3, och de underteman och övergripande teman som identifierats, 
påbörjade skrivandet av studiens resultat- och analyskapitel. Jag började i detta steg att renodla temana och beskriva hur dessa kunde ses i relation till forskningsfrågorna. Detta gjordes bland annat genom att arbeta med den narrativa delen av hur de olika temana hängde samman och att plocka fram uttalanden som var indikativa för varje tema. Detta var en iterativ process som pågick under en längre tid. Processen följde mönstret av att jag arbetade fram ett resultat- och analyskapitel som sedan sattes under granskning av mig själv, kollegor och handledare (vid ett tillfälle även av externa läsare i form av mitt $60 \%$ seminarium). I denna iterativa process förkastades vissa teman, andra teman slogs ihop med varandra eller fördes in i redan existerande teman, medan andra teman istälelt bröts isär till flera teman. I slutet av denna process reducerades den stora mängd uttalanden som använts i texten för att belysa temana och endast de som ansågs vara essentiella för att karakterisera studiens resultat blev kvar. Denna process innebar även att jag behövde uppsöka ny litteratur för att se om detta kunde ge ett annat perspektiv på resultatet. Denna skrivprocess var väsentlig för att jag skulle kunna granska mitt resultat i förhållande till de övergripande forskningsfrågorna, jag kunde alltså genom detta arbete inta ett "helikopterperspektiv" och ifrågasätta huruvida det fanns logik och struktur i det jag skrivit fram.

6. Att skriva fram teman - Det sista steget innebär att forskaren på ett tydligt och trovärdigt sätt skriver fram vad den tematiska analysen betyder i förhållande till forskningsfrågan (Braun \& Clarke, 2006).

Även detta steg skulle kunna sägas ha inletts i föregående steg, men fortsatte sedan i det avslutande arbetet av studien i form av framskrivningen av slutsatserna i relation till resultat och forskningsfrågor. 


\subsection{Validitet}

För att hjälpa läsaren att avgöra om studien som presenteras i denna licentiatsavhandling håller hög validitet eller ej kommer en tydlig redovisning av hela studiens gång att beskrivas, en så kallad audit trail (Robson, 2011). I bilaga 2 finns en beskrivning av vad som hände under studiens olika mötes- och verksamhetsaktioner, samt de beslut som togs under processen. Detta kommer också att vara ett sätt att skapa överförbarhet, det vill säga att en person i en liknande kontext (exempelvis en förskollärare på en annan förskola) ska kunna dra nytta av de lärdomar som framkommit i denna studie (se exempelvis Herr \& Anderson, 2005 och Lincoln \& Guba 1985).

Enligt Herr och Anderson (1999, 2005) så är det vid aktionsforskning viktigt att ta hänsyn till relationen mellan deltagarna och forskaren och hur validitetsfrågan ska hanteras. De menar att validitet inom aktionsforskning inte kan bedömas utifrån traditionella metoder (se även Folkesson, 2012). Istället lyfter de fram fem validitetskriterier unika för just aktionsforskning. Dessa kriterier är processvaliditet (process validity), katalytisk validitet (catalytic validity), dialogisk validitet (dialogic validity), demokratisk validitet (democratic validity) samt utfallsvaliditet (outcome validity).

Enligt Herr och Anderson (2005) handlar outcome validity om att aktioner verkligen sker och att de faktiskt leder till en lösning på det problem som har identifierats. De menar att outcome validity är synonymt med ett lyckat resultat av forskningen. För att detta ska kunna uppfyllas är det viktigt att deltagarna känner att de äger problemet, det vill säga att problemet härrör från själva organisationen (Rönnerman, 2012a; Zeni, 2001).

Catalytic validity handlar enligt Herr och Anderson (2005) om på vilket sätt och i vilken grad som deltagarna och forskaren omvärderar sin syn på verkligheten, samt hur de ser på sin roll i denna. Tanken är att alla deltagarna ska få en större förståelse för den sociala verkligheten och därigenom kunna förändra den. Somekh (2006) beskriver detta som att aktionsforskning ska utgå från en vision för social förändring och för en större social jäm- 
likhet. Catalytic validity handlar också om att deltagarna noga reflekterar över var de står värderingsmässigt i förhållande till problemformuleringen. Locke, Alcorn och O'Neill (2013) ser detta som en viktigt etisk princip vid aktionsforskning.

Catalytic validity hänger delvis samman med process validity som handlar om kvaliteten på relationen/samarbetet mellan deltagarna och forskaren. För forskaren handlar det om att hen måste reflektera över sin egen roll i aktionsforskningsgruppen (Zeni, 2001). Process validity handlar även om huruvida rönen av forskningen är ett resultat av iterativa cykler där den ursprungliga frågeställningen ständigt utmanas, bland annat med hjälp av ett teoretiskt ramverk. Forskaren måste noga beakta gruppens dynamik i planerandet av varje iterativ cykel och utifrån gruppens önskemål, analysen av mötena och analysen av aktionerna plocka fram den forskningslitteratur som är avgörande för nästa iterativa cykel (Herr \& Anderson, 2005).

Herr och Anderson (2005) beskriver democratic validity som ett mått på i vilken utsträckning forskningen görs i samarbete/överenskommelse med alla som på något sätt faktiskt berörs av denna, så kallade stakeholders eller intressenter. Andra medarbetare som jobbar på en förskola/skola men som inte är intresserade av att vara deltagare kan benämnas som intressenter. Andra exempel på intressenter kan vara förskolechef/rektor, barn/elever samt deras vårdnadshavare. Det är viktigt att dessa intressenter får möjlighet att diskutera frågeställningar gällande studiens syfte och design, äganderätten av data, samt spridningen av resultatet (Locke et. al., 2013). Denna form av validitet handlar alltså till stor del om etiska frågeställningar (se även Zeni, 2001). En annan aspekt av democratic validity handlar om vilka förutsättningar som ges för att förändring faktiskt ska kunna äga rum. Utifrån denna aspekt är det viktigt att deltagarna känner att de äger problemet, att de känner sig som just en deltagare, inte ett forskningsobjekt. Denna form av validitet har alltså tydliga kopplingar med outcome validity.

Dialogic validity handlar om det som inom traditionell kvantitativ och kvalitativ forskning brukar benämnas som "peer-review" 
(Herr \& Anderson, 2005). Det kan handla om att aktionsforskare ingår i ett nätverk där de olika forskarnas projekt ställs under granskning genom ett aktivt deltagande i en reflekterande dialog. Det kan också handla om att forskaren skaffar sig en eller flera "kritiska vänner". Ett exempel på kritiska vänner kan vara handledare och doktorandkollegor. De kritiska vännerna ska helst vara "familiar with the setting and can serve as devil's advocate for alternative explanations of research data" (Herr \& Anderson, 2005, sid. 57). Dialogic validity handlar också om överförbarheten till en liknande situation. Ingen kontext är den andra lik och går därför aldrig att översätta rakt av men genom att producera en text med "fylliga" beskrivningar (Larsson, 2005) ska en läsare kunna dra nytta av forskningen i sin egen kontext. Somekh (2006) förklarar detta med att aktionsforskningen ska utveckla unik kunskap och förståelse.

\subsection{Etiska överväganden}

I alla studier är det oerhört viktigt att forskaren noga överväger de etiska dilemman som kan/kommer att uppstå i den tänkta studien. Detta blir dessutom extra viktigt när studien involverar barn, och i synnerhet yngre barn som kanske inte alltid har möjligheten att göra informerade beslut om sitt eventuella deltagande eller ej. Jag kommer därför i följande delkapitel att beskriva vilka etiska överväganden som gjordes relaterade till de barn som var en del av studien. Jag kommer också att beskriva hur jag hanterade etiska dilemman gällande de förskollärare som var en del av studien, samt min egen roll som forskare.

I planerandet av studien utgick jag från Vetenskapsrådets (UÅ) fyra etiska huvudkrav - information, samtycke, konfidentialitet och nyttjande. Jag kommer nedan att beskriva hur detta gjordes i förhållande till alla inblandade. Eftersom det finns stora beröringspunkter mellan etik och metodologi har jag valt att binda samman dessa med hjälp av Herr och Andersons (2005) kriterier för validitet i aktionsforskning som beskrivits ovan och forskning gällande etik i aktionsforskning (se till exempel Locke et al., 2013; Somekh, 2006; Zeni, 2001). För att läsaren dessutom ska kunna bilda sig en så mångfacetterad förståelse av studiens etiska 
överväganden som möjligt kommer det arbete som skedde i gruppen, och de val som gjordes i denna process, att tydligt redovisas i bilaga 2 i form av en kort sammanfattning, i kronologisk ordning, av mötesaktionerna, verksamhetsaktionerna och informationsmötena.

\subsubsection{Etiska överväganden i förhållande till barnen som ingick i studien}

För all forskning som på något sätt innehåller individer är samförstånd en viktig etisk fråga. Samförstånd är dock inte en enkel fråga när forskningen på något sätt inbegriper barn. Barn anses ur ett forskningsetiskt perspektiv vara i ett extra utsatt läge - det är inte säkert att barnen i fråga egentligen vill kunna kopplas till studien, många av dem är fortfarande för små för att själva kunna avgöra detta. För att försöka ta detta i beaktande är det till att börja med praxis att skaffa samförstånd med barnens vårdnadshavare, vilket även gjordes i denna studie. Barnens vårdnadshavare meddelades muntligt av någon av förskollärarna och fick även en samförståndsblankett som jag satt samman som innehöll information om den kommande studien. Vårdnadshavarna ombads att på denna blankett ange om de godkände att deras barn deltog i studien eller ej (se bilaga 1). Jag satte även samman ett informationsmail om studien som först skickades till förskollärarna för påseende, och efter detta vidarebefordrades av dem till respektive avdelnings vårdnadshavare. I samma mail fanns även en inbjudan till ett informationsmöte om studien. Tanken var att det skulle hållas ett informationsmöte på respektive förskola, men trots ett antal påminnelser om detta möte var det endast fem vårdnadshavare som anmälde sig. Det bestämdes därför att jag och en av förskollärarna skulle hălla mötet på en av förskolorna, väl på plats var det endast två vårdnadshavare som deltog. En förklaring till detta skulle kunna vara att vårdnadshavarna överlag inte såg frågor relaterade till teknik och genus som något prioriterat. En enkätstudie bland 1700 förskollärare visade till exempel att när pedagogerna skattade de förväntningar de ansåg att vårdnadshavarna hade på organisationen så hamnade jämställdhetsarbete bland de mindre prioriterade frågorna (Tallberg Broman, 2009). 
Informationen som på dessa olika sätt gick ut till vårdnadshavarna beskrev syftet med studien, hur studien skulle gå till, samt hur det empiriska materialet skulle behandlas. Vårdnadshavarna fick information om att ingen, förutom aktionsforskningsgruppen och mina handledare, skulle ha tillgång till det inspelade videomaterialet av verksamhetsaktionerna. Att skaffa samförstånd med vårdnadshavare är dock bara en del av att säkerställa ett etiskt tillvägagångssätt när det handlar om barn. I en studie som involverar barn är det viktigt att forskaren, under hela processen, har de etiska aspekterna aktualiserade, genom att hen ser barnen som medforskare. Detta kan samtidigt bidra till att jämna ut maktförhållandena mellan forskare och barn (Pirini et al., 2014).

I de verksamhetsaktioner som genomfördes tillsammans med barnen på de olika avdelningarna gjordes sedan en rad olika åtgärder för att ytterligare säkerställa det etiska tillvägagångssättet. Till att börja med såg jag till att jag inför aktiviteterna spenderade lite tid på respektive avdelning för att presentera mig för barnen. Under dessa korta pass berättade jag inte enbart för barnen varför jag var på förskolan, vad jag jobbade med eller hur videokameran fungerade, utan jag spenderade även lite tid med dem i allmänhet. Detta gjordes för att de skulle känna sig mer bekväma med min närvaro och att de förhoppningsvis därför skulle kunna vara mer frispråkiga om det var så att de inte ville vara med i studien. Jag hade från början tänkt att spendera betydligt mer tid på avdelningarna, i synnerhet inför den första aktiviteten, men pedagogerna var tydliga med att förklara att det skulle räcka med en kort stund före varje tillfälle. De menade att barnen snabbt skulle välkomna mig ändå - vilket också visades sig stämma, det tog inte lång tid innan jag var "Johan" för barnen.

De barn som deltog i aktiviteterna valdes ut av pedagogerna på respektive avdelning. Det var endast de barn vars vårdnadshavare hade fyllt i ett jakande svar på samförståndsblanketten som deltog i de videoinspelade verksamhetsaktionerna. Sammanlagt deltog mellan 10 - 12 barn från varje avdelning i studien. För att se till att mötet med studiens teknikdidaktiska innehåll inte enbart var exklusivt för de barn som deltog i verksamhetsaktioner- 
na så skapade pedagogerna även tillfällen för detta för resterande barn. Detta skedde kontinuerligt under det år som studien fortlöpte. För att säkerställa att barnen samtyckte till sitt deltagande i de olika verksamhetaktionerna försökte jag att vara så observant som möjligt, under introduktionsfasen av respektive verksamhetsaktion, på om något barn tydligt uttryckte att de hellre ville göra något annat. $\mathrm{Nu}$ var det inget barn som visade några tendenser till detta, men om det hade funnits någon som gjort detta så hade det barnet istället fått återansluta sig till resten av sin avdelning. Det bör dock tilläggas att det var en del barn, i synnerhet bland de yngre, som efter att arbetet varit igång ett bra tag uttryckte att de ville göra något annat - de frågade exempelvis om de fick gå ut och leka eller om det inte var dags att äta mat snart. I dessa fall valde jag att låta pedagogerna hantera situationerna utifrån deras förförståelse av de olika barnen och deras erfarenheter av liknande situationer i de dagliga aktiviteterna. I vissa fall gav de barnen motivation att fortsätta med aktiviteten medan de i andra fall släppte iväg barnen.

I den ringa utsträckning som några av barnen figurerar i det empiriska materialet som återges i den här licentiatsavhandlingen så har de blivit avidentifierade. Eftersom det inte har varit verksamhetsaktionerna som har varit huvudfokus i studien så förekommer endast barnen i form av att deltagarna i gruppen återkopplar till vad som hände under dessa, alternativt att något barn dyker upp i gruppens kommenterar om vad som händer på de videosekvenser vi tittade på under mötessaktionerna.

\subsubsection{Etiska överväganden i förhållande till deltagarna i studien och andra vuxna}

Herr och Anderson (2005) menar att för att en aktionsforskningsstudie ska kunna nå ett lyckat resultat så är det viktigt att deltagarna äger problemet, det vill säga att problemet härrör från själva organisationen. Rönnerman påpekar att:

Genom att aktionsforskning är praktikerorienterad, är det den egna praktiken som är i fokus för en aktion. Det är praktikern som formulerar vad som ska studeras och vilka frågor man vill ha kun- 
skap om. Det är praktikern som formulerar vad som ska studeras och vilka frågor man vill ha kunskap om. (2012a, sid. 22 - 23)

I förhållande till denna studie går det att ställa sig frågan i vilken utsträckning frågeställningen kom från praktikerna själva? Det var nämligen jag som under ett inledande informationsmöte presenterade de grundläggande förutsättningarna för forskningen. Jag berättade att den skulle handla om teknik i förskolan med ett särskilt fokus på genus. Det går alltså att konstatera att det var jag som stakade ut vägen för vilket område som problemformuleringen skulle röra sig inom, vilket går lite stick i stäv med aktionsforskning som metod. Även om jag hade en viktig del i formulerandet av problemområdet så fanns det dock en koppling mellan detta område och de förskolor där studien genomfördes. Min kontextuella förförståelse av de förskolor som ingick i studien spelade en viktig roll i att det var just dessa som jag kontaktade. För det första har kommunen som förskolorna tillhör aktiva mål gällande både teknik och genus. För det andra visste jag att en del av pedagogerna på respektive förskola hade gått en universitetskurs i genuspedagogik, medan andra hade läst en kurs i teknik/naturvetenskap. För det tredje hade jag även en viss insyn i de två förskolornas organisation och visste att de arbetat med att utveckla organisationen ur ett genusperspektiv, samt arbetat med att utveckla teknikaktiviteter. Jag förutsatte därför att min utstakning av problemområdet inte skulle vara för styrande utan faktiskt haka samman med redan aktiva diskussioner bland deltagarna. Jag tänkte även att dessa faktorer kunde ses som en god grund för att en del av de två förskolornas pedagoger skulle knyta an till studiens premisser, vilja bli en del av den och förhoppningsvis fullfölja den till slutet. Det som visade sig när väl gruppen hade formerats var att deltagarna visserligen enkelt kunde knyta an till problemdiskussioner gällande både teknik och förskola samt genus och förskola, men att det var svårare för dem att definiera ett tydligt problemområde i skärningspunkten mellan teknik och genus. Det var först efter att studien pågått ett tag som detta skedde i gruppen.

Enligt Vetenskapsrådet (UÅ) så är det viktigt att deltagarna i en forskningsstudie är involverade av egen vilja och känner att de har möjlighet att lämna studien om de skulle vilja det. Detta är 
även något som Locke et al. (2013) beskriver som en mycket viktig etisk princip när det kommer till aktionsforskning. En annan viktig etisk aspekt inom aktionsforskning är att alla vars praktik, kunskap och identitet som forskningen berör ska vara berättigade att bli medlem av forskningsgruppen (Locke et al., 2013). Det är därför intressant att beskriva den process som ledde fram till formerandet av aktionsforskningsgruppen i denna studie. Embryot till detta startade när jag kontaktade förskolechefen för de två förskolorna, dessa kommer hädanefter att bli benämnda Anod och Katod. I början av höstterminen 2014 träffade jag förskolornas förskolechef och den biträdande förskolechef. Under detta möte diskuterades studiens syfte och premisser, vilket resulterade i att jag blev erbjuden att genomföra studien tillsammans med pedagogerna på Anod och Katod. Förskolecheferna informerade mig om att de kunde avsätta två timmar, under arbetstid, i månaden för gruppens mötestid. I november 2014 medverkade jag som en del av dagordningen på ett stormöte för personalen på båda förskolorna. Jag var noga med att flera gånger under mötet påpeka att deltagande i studien skedde helt av fri vilja. Jag blev dock tvungen att trycka på detta fler gånger än jag hade planerat eftersom en av förskolecheferna i början av mötet tydligt berättade för alla de samlade pedagogerna om vilken utvecklingsmöjlighet det var att få ingå i denna grupp. Detta gjordes troligtvis enbart i välmening från förskolechefens sida men jag ansåg att det medförde en risk i form av att någon av de närvarande bestämde sig för att delta enbart på grund av att ledningen förväntade sig det. Pedagogerna fick därefter cirka två månader på sig att fundera på om de ville delta eller ej. I februari 2015 träffade jag återigen förskolecheferna och fick då reda på att åtta förskollärare visat intresse att ingå i gruppen. Tre stycken från Anod och fem stycken från Katod. Alla åtta pedagoger hade arbetat i förskolan i åtminstone tio år. Alla pedagogerna identifierade sig som kvinnor och befann sig någonstans i åldersspannet 35 - 55, men eftersom det har visat sig att varken förskollärares kön eller ålder spelar någon roll för hur de förhåller sig till barnen kommer dessa aspekter inte att lyftas upp mer ingående (se Eidevald, 2009). Mig själv inräknad kom gruppen vid start alltså att bestå av nio medlemmar, vilket gör att den ligger precis över gränsen för vad som kan anses optimalt för forskningens syfte. 
Persson (2008) menar att en forskningsgrupp som har som mål att utveckla en organisation som den själv är en del av, i bästa fall bör bestå av fem till åtta deltagare. Detta gjorde att jag var tvungen att fundera på om gruppen skulle delas i två mindre grupper eller om den större gruppen skulle hållas intakt. Valet föll på det senare utifrån två huvudanledningar. För det första är det inte ovanligt att det under längre studier uppstår situationer som gör att deltagare tyvärr måste lämna gruppen, det kan handla om något så enkelt som byte av arbetsplats, men även om sjukdom eller liknande. Om jag hade delat gruppen i två så hade varje grupp bestått av fem personer (mig själv inräknad). Grupperna hade i sådana fall blivit väldigt sårbara för avhopp. Om gruppen är litet större från början är den däremot inte lika känslig för avhopp. Under projektets gång, strax efter verksamhetsaktion 2, visade det sig att en av deltagarna var tvungen att lämna gruppen på grund av sjukdom. För det andra, och betydligt viktigare, så visade det sig att de som anmälde sig till studien var helt inställda på att detta var något de skulle göra tillsammans.

Två särskilda intressenter i studien var förskolechefen och den biträdande förskolechefen. Dels gav de tid och resurser till projektet, dels påpekade de att de såg forskningen som ett sätt att utveckla verksamheten. Det hade varit möjligt att bjuda in dem till gruppens mötesaktioner, men eftersom det i relationen chef och anställd finns en maktdimension valde jag att inte göra detta (Herr \& Anderson, 2005).

\subsubsection{Etiska överväganden i förhållande till min egen roll i studien}

I planerandet av mötesaktionerna och i analysen av det empiriska materialet är det viktigt att jag är medveten om mina egna värderingar och förutfattade meningar. Jag måste vara kritisk till hur min förförståelse och mina erfarenheter påverkar mina tolkningar och slutsatser (Locke et al., 2013). Även mina personliga reflektioner utifrån min plats som forskare i studien och vad jag för med mig blir i detta avseende viktiga (Zeni, 2001). Utifrån detta har jag försökt att så tydligt som möjligt, både i inledning och i bakgrund och tidigare forskning, att dels skriva fram varför 
denna studie är viktig, och dels skriva fram vilken kunskap och förståalse som har informerat analysen. I denna framskrivning, men även i förmedlandet av forskningen som helhet, är det också viktigt att jag går tillväga på ett sätt som maximerar förståelse, kännetecknande för en sådan kommunikation är att den inte innehåller onödig jargong (Locke et al., 2013).

Somekh (2006) beskriver att ur ett etiskt perspektiv är det viktigt att aktionsforskningen sker i en kollaborativ process mellan deltagare och forskare, och att denna process kännetecknas av en hög nivå av reflektion. Det är därför viktigt att beskriva min relation med de pedagoger som valde att bli en del av studien. Av de tre pedagogerna som deltog från Anod så hade jag tidigare mött två av dem, och av de fem pedagogerna från Katod så hade jag mött tre. Att jag sedan tidigare vet vilka några av deltagarna är medför både för- och nackdelar. Fördelarna hänger delvis samman med studiens processvaliditet som handlar om kvaliteten på det kollaborativa arbetet i gruppen (Herr \& Anderson, 2005). Enligt Robson (2011) så reduceras deltagarbias genom att deltagarna känner sig säkra i situationen, både med varandra och med forskaren - de säger vad de faktiskt tycker och tänker. Om deltagarna inte är bekanta med varandra och/eller forskaren brukar det ta ett antal träffar innan detta tillstånd uppnås. Herr och Anderson (2005) menar att om en aktionsforskningsstudie ska uppnå god validitet så måste det finnas en relation mellan de olika deltagarna, forskaren inkluderad. Att jag redan var ett bekant ansikte hos fem av deltagarna kan därmed verka för ett positivt utfall av studien. Å andra sidan menar Robson (2011) att det finns en större risk för forskarbias ju längre ett projekt pågår. En nära relation med deltagarna kan påverka forskaren att tolka det som händer i gruppen i ett alltför positivt ljus. Att jag och några av deltagarna var bekanta ansikten för varandra sedan innan medförde alltså en risk att detta skulle kunna bidra till ytterligare forskarbias. I detta avseende gäller det alltså att jag är uppmärksam på att jag verkligen försöker inta ett så objektivt sinnelag som möjligt när det kommer till att analysera deltagarnas handlingar och ord. Till min hjälp i detta har jag även haft mina två handledare som sett delar av det inspelade videomaterialet och läst delar av transkriptionerna. På frågan om en hög nivå av re- 
flektion för gruppen finns inget enkelt svar, utan varje grupp har en unik dynamik och existerar i en unik kontext. Rollen för mig som forskare blir att noga beakta denna dynamik i planerandet av varje iterativ cykel. Att utifrån gruppens önskemål och min analys av föregående möte identifiera riktning på kommande möte. Här finns det naturligtvis en risk att jag återigen blir den styrande i gruppen, därför är det viktigt att jag från början tydliggör att alla deltagare har möjlighet att föreslå riktning i planerandet av de olika aktionerna. Vad det gäller att lyssna in gruppens dynamik så kunde jag dra nytta av mina 15 års erfarenhet av att ha hanterat grupper i en klassrumssituation, både barn och vuxna, samt att jag även privat varit involverad i ledningsgrupper i några olika organisationer. Vad det gäller det kollaborativa samarbetet är det också viktigt att jag ser till så att det inte är jag som styr gruppen för mycket. Under studiens gång kommer jag därför, vid tillfälle, att samtala lite kort med varje deltagare för att se hur de upplever min roll; är det jag som styr, är jag en deltagare bland alla andra, etcetera? Här tänker jag mig att det faktum att jag inte är en okänd enhet för deltagarna skulle kunna bidra till att de faktiskt säger vad de tycker och tänker.

\subsection{Urvalet av filmsekvenser från verksamhetsaktionerna}

Vid gruppens reflektions- och analysfas i de olika cyklerna användes filmsekvenser hämtade från den aktuella cykelns genomförda verksamhetsaktioner. Efter varje verksamhetsaktion var det min uppgift att titta igenom det inspelade materialet, 5 - 6 filmer på 6o - 90 minuter vardera, och hitta filmsekvenser som representerade någorlunda generella aspekter i förhållande till det identifierade utvecklingsområdet - vad som skulle kunna benämnas som röda trådar som löpte genom cykelns verksamhetsaktion. Det kunde exempelvis handla om liknande sätt hos deltagarna att förhålla sig till och bemöta barnen. Innan jag tog med dessa filmsekvenser till gruppen började jag med att visa dem för mina handledare för att se om de höll med om min analys. 


\subsection{Att vara en del av reproduktionen}

Innan jag beskriver resultatet av studien är det dock av vikt att ägna uppmärksamhet åt att jag i hela licentiatavhandlingen diskuterar teknik i förhållande till femininitets- och maskulinitetsnormer. Det är även så att ett fokus för verksamhetsaktionerna blev hur flickor respektive pojkar agerade i och förhöll sig till dessa. Genom detta fokus blir även vi i aktionsforskningsgruppen en del av återskapandet av flickor och pojkar som separata grupper i förhållande till teknik. Detta är ett dilemma som kan vara svårt att undkomma när det handlar om att undersöka teknik och genus i en utbildningskontext. Syftet är ofta att undersöka mer generella strukturer i förhållande till teknik och genus, och att därigenom kunna peka på intressanta slutsatser i förhållande till barns lika möjligheter, rättigheter och skyldigheter i verksamheten/undervisningen. Å ena sidan riskerar synliggörandet av dessa aspekter, att i värsta fall, konservera rådande strukturer. Å andra sidan kan det vara svårt att ändra på strukturer om de inte först har lyfts upp till ytan för kritisk granskning. I slutändan kanske det inte finns en korrekt väg fram i denna fråga utan det viktiga blir istället att alla som är involverade i arbetet är medvetna om att dilemmat existerar. 



\section{Kapitel 5}

\section{Resultat och analys}

Transkriptionerna av mötesaktionerna lästes och kodades med de didaktiska frågorna vad, varför, hur och för vem som grund. Utifrån denna kodning kunde sedan gruppens didaktiska resonemang identifieras och kategoriseras i teman och underteman. Följande kapitel - resultat och analys - kommer alltså att hjälpa till att ge svar på studiens första frågeställning - vilka didaktiska resonemang blir synliga i planering och utvärdering av aktioner kopplade till teknik och genus i förskolan? I diskussionen (kapitel 6) kommer sedan dessa teman att användas för att besvara studiens andra frågeställning - vilka utmaningar och möjligheter finns i förskolans arbete med genus och teknik? - utifrån gruppens didaktiska resonemangen i relation till målet att utveckla en teknikdidaktisk verksamhet $\mathrm{i}$ förskolan som inte begränsas av traditionella könsroller. En helhetsläsning av bilaga 2 (Sammanfattning av mötesaktioner, verksamhetsaktioner och informationsmöten) kan fördjupa läsarens förståelsen av följande resultat- och analyskapitel.

Följande teman och underteman identifierades.

Tema

Undertema

\begin{tabular}{|l|l|}
\hline $\begin{array}{l}\text { Pedagogens roll i organisering- } \\
\text { en av aktiviteterna }\end{array}$ & Personligt förhållningssätt \\
\cline { 2 - 2 } Innehåll som barnen făr möta & $\begin{array}{l}\text { Aktivitetens ramar traditionellt sett manliga } \\
\text { sfären av teknik }\end{array}$ \\
\cline { 2 - 2 } & Stereotyp teknik \\
\hline \multirow{4}{*}{$\begin{array}{l}\text { Barnens egenskaper och karak- } \\
\text { tärsdrag }\end{array}$} & $\begin{array}{l}\text { Att konstruera för konstrue- } \\
\text { randets skull eller för en kon- } \\
\text { text }\end{array}$ \\
\cline { 2 - 2 } & $\begin{array}{l}\text { Att vara en snabbtänkt görare } \\
\text { eller inte }\end{array}$ \\
\hline & $\begin{array}{l}\text { Förutbestämda egenskaper el- } \\
\text { ler påverkan av erfarenheter }\end{array}$ \\
\hline
\end{tabular}


Jag kommer att presentera dessa tre teman var för sig i delkapitel 5.1, 5.2 och 5.3. De kommer dock att presenteras med något olika upplägg. Det andra (kapitel 5.2) och det sista temat (kapitel 5.3) kommer att skrivas fram med en tydlig uppdelning utifrån sina underteman. Pedagogens roll i organiseringen av aktiviteterna (kapitel 5.1) kommer däremot inte att delas upp i sina underteman. Istället kommer dessa att presenteras genom ett narrativ som rör sig mellan respektive undertema. Anledningen till att jag inte delat upp detta kapitel utifrån underteman beror på att dessa hakade samman i varandra under själva aktionsforskningsprocessen, där diskussioner som går att kategorisera till det ena undertemat påverkade och förändrade hur gruppen diskuterade aspekter som faller inom det andra undertemat. Om dessa underteman beskrivits var för sig hade denna påverkan och förändring varit svår att belysa.

I relation till den första forskningsfrågan, didaktiska resonemang, så relaterar det första temat, pedagogens roll i organiseringen av aktiviteterna, till den didaktiska frågan av hur ett ämnesstoff ska läras ut. Det andra temat, innehåll som barnen får möta, går att koppla samman med frågan om vad för slags innehåll som ska läras ut. Det tredje och sista temat, barnens egenskaper och karaktärsdrag, rör frågan om för vem?, det vill säga hur pedagogerna ser på barnen i förhållande till aktiviteternas innehåll. Den didaktiska frågeställningen varför löper igenom alla tre teman.

\subsection{Pedagogens roll i organiseringen av aktiviteterna}

Detta huvudtema innehåller undertemana personligt förhållningssätt och aktivitetens ramar. Det första undertemat handlar om aspekter som går att koppla till deltagarnas syn på sig själva och förståelsen av sitt eget agerande. Det andra undertemat handlar istället om de organisatoriska ramar som påverkar aktiviteten, barnen och pedagogen. Jag kommer i detta delkapitel att lyfta fram hur deltagarnas upptäckter och reflektioner kring dessa aspekter informerade och förändrade deras syn på pedagogens roll i en teknisk aktivitet. 
Undertemat det personliga förhållningssättet går att belysa genom att starta i hur deltagarna, i studiens initiala skede, beskrev de tekniska aktiviteterna och sitt bemötande av barnen utifrån ett genusperspektiv. De flesta av dem hade väldigt svårt att se hur förskolans tekniska aktiviteter gick att relatera till just genus över huvud taget och om det därför fanns någon problemformulering att identifiera i förhållande till detta, eller som Jenny uttryckte det:

Sen tycker jag man ser teknik hela tiden, men just att kontra det till genus. Det tyckte jag var lite svårt.

Deltagarna menade att det i allmänhet inte är särskilt svårt att identifiera den vardagsteknik som genomsyrar samhället, det vill säga den teknikkontext som barnen befinner sig i, men att det är betydligt svårare att se hur detta ska belysas och problematiseras ur ett genusperspektiv. Det fanns tecken i deltagarnas uttalanden och meningsutbyten som pekar på att svårigheten med att se detta hänger samman med deras grundläggande antagande om hur barnen bemöts på förskolan. Ett uttalande från Sara kan användas för att belysa denna genomgående syn hos deltagarna.

Och sen ska man koppla det (teknik, min anmärkning) till genus också, för vi gör inte det normalt sett, utan vi erbjuder alla. Då låser det sig lite men jag är laddad för att fortsätta.

Deltagarna utgick alltså från förhållningssättet att på förskolan så erbjuds alltid alla barn, oavsett kön, samma möjligheter i verksamheten. Detta kan ses som ett fall av att människor i allmänhet utgår från att de agerar på ett jämställt sätt, även om så inte alltid är fallet.

Något som deltagarna däremot var relativt snabba med att diskutera i början av studien var att de ville studera hur de förhöll sig i sin ledarroll i förskolans tekniska aktiviteter. I detta resonemang om att studera ledarrollen går det att se att de utgår från att deras sätt att agera i aktiviteterna och hur de bemöter barnen är något som behöver arbetas vidare med och utvecklas. De verkar alltså vara överens om att det finns faktorer som påverkar deras agerande i mötet med barnen, exempelvis om de har en positiv in- 
ställning i sitt bemötande eller ej. Men utifrån deltagarnas uttalanden om att de alltid erbjuder barnen, oavsett kön, lika möjligheter så verkar inte genusstrukturer vara en sådan faktor.

Det som fick störst plats i diskussionerna om ledarrollen handlade om hur pass aktiv pedagogen är i mötet med barnen i den tekniska aktiviteten. Två olika sätt att positionera sig lyftes fram av gruppen, antingen som aktiv vuxen eller som en bredvidsittande medupptäckare. Med aktiv vuxen menades i detta fall att pedagogen har ett tydligt syfte och mål med aktiviteten. Definitionen av en bredvidsittande medupptäckare handlade om att pedagogen enbart ger barnen tillgång till ett visst material och sedan sitter bredvid medan barnen arbetar mer fritt med detta. Diskussionerna utmynnade i att gruppen bestämde sig för att den första verksamhetsaktionen skulle vara en aktivitet med en aktiv vuxen och att nästkommande verksamhetsaktion skulle vara en aktivitet där pedagogerna skulle inta rollen som bredvidsittande medupptäckare. Tanken med detta var att jämföra deltagarnas bemötande av barnen i dessa olika roller.

När gruppen sedan analyserade vad som hände under verksamhetsaktion 1, där pedagogerna hade intagit rollen som aktiv vuxen, så går det att se att diskussionerna skiftade till aspekter av det andra undertemat - aktivitetens ramar. Deltagarna menade att saker inträffat som gjorde att de kände att de delvis tappade kontrollen över situationen. Dels kände de att de hade haft svårt att hantera säkerhetsaspekter när barnen använde sig av de verktyg (skruvmejsel, drillborr, etcetera) som fanns tillgängliga för att sammanfoga materialet. Ett exempel på detta kan ses i följande diskussion om hur vissa av barnen använde skruvmejslarna för att hugga i pappkartongerna.

Susanne: Sen spårade det ju lite ur med dom här (hugger med handen i luften).

Anna: Jag såg att du såg svettig ut.

Susanne: Ja men, alltså jag blev lite nervös när de sitter och hugger.

Anna: Jag förstår det.

Lena: Men så tyckte ju våra också om (hugger med handen, vänder sig mot Eva)

Eva: Ja, ja. 
De menade även att de hade varit tvungna att gå in och avstyra potentiella konflikter under aktionen, i synnerhet gällde det de deltagare som hade genomfört aktioner med yngre barn. Slutsatsen av detta blev att fortsätta studera just aktiviteter där pedagogerna intar rollen som aktiv vuxen. Det bör dock påpekas att detta skifte i fokus inte var något som skedde per automatik utan i detta avseende spelade jag, i form av handledare, en viss roll. I nedanstående utdrag går det att se att det är jag som, utifrån hur pedagogerna själva tidigare diskuterat säkerhetsaspekter och gruppstorlek, utmanar deras ursprungliga tanke om att nästa aktivitet kanske inte ska vara en medupptäckaraktivitet.

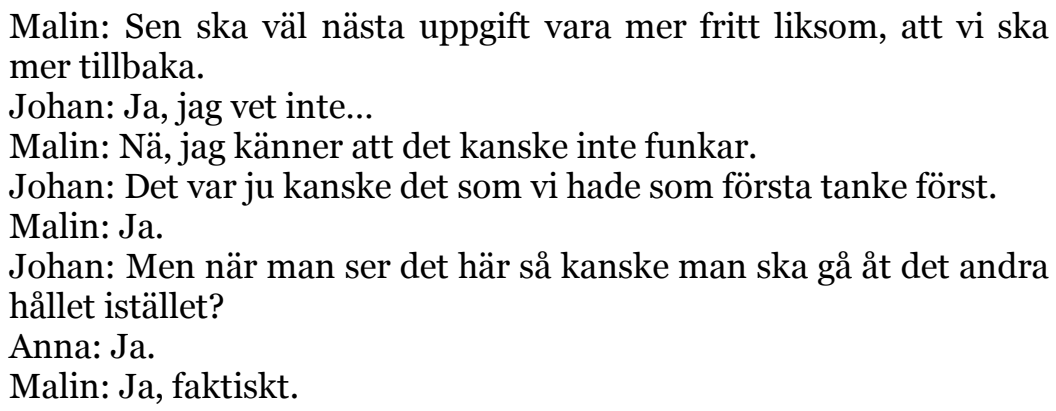

Malin: Sen ska väl nästa uppgift vara mer fritt liksom, att vi ska mer tillbaka.

Johan: Ja, jag vet inte...

Malin: Nä,jag känner att det kanske inte funkar.

Johan: Det var ju kanske det som vi hade som första tanke först.

Malin: Ja.

Johan: Men när man ser det här så kanske man ska gå åt det andra hållet istället?

Anna: Ja.

Malin: Ja, faktiskt.

Deltagarna var dock snabba med att plocka upp idén om att även i nästa aktion ha den aktiva vuxna $i$ fokus och göra den till sin egen. Vilket kan belysas med följande samtal mellan Malin och Jenny.

\footnotetext{
Malin: Ja, vi har ju en rätt viktig roll, så jag tänker att vi inte kan släppa för mycket faktiskt.

Jenny: Nä.

Anna: Nä. Nä, precis, det är sant Malin.

Malin: Att vi har en uppgift här liksom.
}

De menade att om de vill synliggöra tekniken på bästa sätt för barnen är det viktigt att de intar en mer styrande roll i den tekniska aktiviteten.

Deltagarnas förslag på hur den pedagogiska rollen skulle kunna utvecklas till verksamhetsaktion 2 föll alla inom undertemat aktivitetens ramar. Det handlade dels om ett, för aktiviteten, tydli- 
gare avgränsat område, dels genom användandet av ett bättre anpassat material, och till sist genom antalet barn som ingick i aktiviteten.

Det tydligare avgränsade området handlade om att aktiviteten borde utföras på exempelvis en matta eller ett bord, och att detta skulle underlätta samarbetet i aktiviteten.

Eva: Ja, skiva, bord, nån slags så.

Jenny: Ja, det kan jag tänka mig också.

Malin: Ja, för vi hade ju bara...

Eva: Golvet är ju ganska stort, alltså så.

Susanne: Vi började ju på de här bänkarna först, men det gick ju inte för det tog stor plats, alltså de byggde ju var för sig så då behövde dom ju ner på golvet.

Det bättre anpassade materialet handlade om att barnen skulle slippa lägga tid på att sortera upp delar som var kompatibla med varandra, i detta fall handlade det om skruvar, muttrar och gångjärn.

Vad det gällde antalet barn menade deltagarna att det var mycket svårt för en ensam pedagog att hjälpa fyra barn att hålla fokus på uppdraget i aktiviteten. De uttryckte till och med förvåning över att de, med tanke på deras långa erfarenhet i yrket, inte ens reflekterat över detta inför den första verksamhetsaktionen.

Susanne: Det skulle vi ju ha tänkt på helt enkelt, att det skulle ha varit färre barn såklart.

Johan: Ja.

Anna: Ja, vi har ju bara jobbat i 25 år snart allihop.

$\AA$ andra sidan lyfte de att det inte är en särskilt vanlig situation att en pedagog har färre än fyra barn i en aktivitet. Ett mer vanligt scenario är att det är åtminstone fyra barn, om inte fler, närvarande.

Lena: Fast det är ju inte ovanligt, överlag, att man har fyra barn när man gör någonting.

Sara: Nä.

Anna: Nä.

Jenny: Nä, det är minimum nästan va. 
Utifrån analysen av verksamhetsaktion 1 förändrades alltså problemformuleringen till att fokusera mer koncentrerat på hur deltagarna agerade i sin ledarroll, det som även hade benämnts som rollen som aktiv vuxen. Det bestämdes att konstruktionsarbetet i verksamhetsaktion 2 skulle ske vid tydliga och avgränsade platser (i detta fall vid ett eller två lägre bord). Det bestämdes även att arbetet skulle ske med hjälp av ett mer användarvänligt och bättre, för ändamålet, anpassat material (gångjärn och rätt dimensionerade skruvar med tillhörande vingmuttrar), samt att de pedagoger som arbetade i par skulle jobba med fyra barn, medan de som var ensamma endast skulle ha med sig två barn i nästa verksamhetsaktion.

I förhållande till pedagogens roll i organiseringen av aktiviteterna går det att se att det var undertemat det personliga förhållningssättet som var i fokus under planeringen av verksamhetsaktion 1. I gruppens analys av verksamhetsaktionen identifierades problem som uppstått under aktiviteten och hur dessa skulle kunna lösas inför verksamhetsaktion 2. Dessa föll alla inom det andra undertemat, aktivitetens ramar.

Utifrån gruppens analys av den andra verksamhetsaktionen går det sedan att konstatera att gruppens förståelse av problemformuleringen fördjupades och återigen delvis skiftade fokus till att mer beröra undertemat det personliga förhållningssättet. Deltagarna menade att de förändringar som gjordes inför verksamhetsaktion 2 gav både dem själva och barnen bättre förutsättningar för aktivitetens problemlösningsarbete - aktiviteterna fungerade helt enkelt mer tillfredsställande än de gjort under verksamhetsaktion 1 . Detta kan ha varit en anledning till att pedagogernas agerande och bemötande av barnen ställdes under en större kritisk granskning, frågor av mer praktisk natur var så att säga röjda ur vägen. Genom det inspelade videomaterialet av verksamhetsaktion 2 blev det tydligt för deltagarna att den bild de haft av vad som hände under verksamhetsaktionen inte riktigt stämde överens med vad som faktiskt skedde. En del av deltagarna menade att de under aktiviteten hade haft känslan av att alla 
barn deltog lika mycket, eller i alla fall deltog på lika premisser. Detta visade sig nu inte vara helt korrekt.

Lena: Ja. Det var ju väldigt intressant egentligen för man hade ju en upplevelse av att, att dom var med allihop.

Sara: Ja, men det hade jag också.

Dessa upptäckter medförde sedan att deltagarna började ifrågasätta om deras syn på sig själva och sitt eget agerande - att de alltid gav alla barn samma förutsättningar - verkligen var korrekt. Utifrån aspekter som går att koppla till det personliga förhållningssättet identifierade deltagarna att de inte alltid var medvetna om att vissa oegentligheter skedde mellan barnen i aktiviteterna. Exempelvis konstaterade gruppen att pojkarna oftare tog utrymme på bekostnad av flickorna än vice versa, men att de under aktiviteten hade tyckt att alla barn fick liknande utrymme. Dessa oegentligheter kunde handla om att en pojke plockade material ur en flickas hand, att en pojke hämtade saker till pedagogerna trots att en flicka hade fått frågan eller att flickorna tittade på medan pojkarna använde materialet (exempelvis skruvdragaren), men när det blev flickornas tur gick pojkarna och gjorde något annat. Det bör naturligtvis påpekas att detta inte var ett beteende som gruppen kunde observera hos alla pojkar som deltog i verksamhetsaktionerna, men det var ett beteende som inte kunde identifieras bland flickorna. Det sistnämnda, intresset/ointresset för vad de andra barnen gör, var ett beteende som en av deltagarna observerade $i$ en annan aktivitet hon genomförde på sin avdelning där två flickor och två pojkar utförde en aktivitet tillsammans.

Sara: Flickorna var väldigt intresserade när pojkarna hade uppgift /.../ men när det blev flickornas (tur, min anmärkning) sen då var det inte riktigt (visar "rycker på näsan"), då var dom (pojkarna, min anmärkning) intresserade av varandra.

Det blev även genom det inspelade materialet tydligt för deltagarna att de själva, vid upprepade tillfällen, under verksamhetsaktion 2 hade låtit pojkarna ta plats före flickorna. Dels handlade det om att de lät pojkarna inta (i vissa fall handlade det till och med om att de armbågade sig fram till) en mer central fysisk po- 
sition vid materialet/verktygen och/eller hos pedagogen. Det handlade också om att de vid upprepade tillfällen under själva konstruktionsarbetet vände sig mot pojkarna i första hand.

Jenny: Men pojkarna börjar ju hela tiden.

Eva: Ja, vi ser...

Jenny: Och ändå är vi medvetna och vi ska tänka.

Eva: Ja.

Sara: En jämställd förskola.

Anna: Eller hur!

/.../

Susanne: Jag tänkte på en annan sak också, det här när ni säger, det är Sara som säger det, men just, "först är det du, du, du (varje "du" representerar en pojke, min anmärkning) och sen făr vi låta Sasha sen.

Jenny: Ja (skratt).

Sara: Ja. (skratt).

Susanne: Och då blir man så här - vadå låta?

Som syns i ovanstående meningsutbyte var detta beetende, där deltagarna placerade pojkarna före flickorna, något som upppengarligen skavde med den bild de hade av hur de tänkte sig att de vanligtvis behandlar barnen i en aktivitet.

Deltagarna verkar också ha haft olika förväntningar på barnens förmågor att hantera verktygen, där de tillskrev pojkarna mer självständighet i användandet av dessa. Detta agerande hos sig själva var något som inte verkar ha varit synligt för alla innan filmklippen visades under en av mötesaktionerna. Susanne kan användas som ett exempel på detta. När gruppen tittade på hennes aktion förklarade hon först varför hon håller undan borrmaskinen från flickan i aktiviteten (hon hade i denna aktivitet en flicka och en pojke).

Susanne: Ja, hon ville ta borrmaskinen men jag vill inte att hon ska ta borrmaskinen, alltså jag vill inte att hon tar den själv. För det är ju också, jag vet ju att dom här två, alltså vi kunde haft hål i hela... (skratt).

Hon upptäckte dock att hon inte var konsekvent med detta handlande när det kom till pojken. Istället för att hålla borrmaskinen 
borta från honom frågar hon om han vill ha den. Denna upptäckt verkade vara något känsloladdad.

Susanne: "Ska du ha borrmaskinen?". Oh my god! "Ska du ha borrmaskinen?" (pratar om hur hon frågar pojken i aktionen om han vill ha borrmaskinen, min anmärkning).

Anna: Ja, det är jobbigt ibland

Deltagarna kunde alltså konstatera att de inte gav samma förutsättningar till de olika barnen i aktiviteterna, och att det i synnerhet var pojkarna som fick fördelar. Detta blev för vissa av deltagarna en något upprörande upptäckt. De började i detta skede att ifrågasätta utgångspunkten som de haft i början av studien, det vill säga att de som pedagoger alltid ser till att ge alla barn samma möjligheter i förskolans aktiviteter. De diskuterade det utifrån aspekten av att de faktiskt kanske har förgivettagna antaganden på barnens agerande, och att de inte riktigt reflekterat över detta i förhållande till genusstrukturer.

Eva: Och att vi är så vana vid just det beteendet som våran man har, att ta mycket plats (pratar om hur ett av barnen agerade $i$ aktiviteten $i$ aktion 2, min anmärkning). För så länge det flöt på bra så kanske vi kände att, jag vet inte.

Anna: Då behöver vi ju verkligen ruskas om, om vi blir vana vid att det ska vara så.

En del av dem verkade enbart genom analysen av verksamhetsaktion 2 ha börjat ifrågasätta sin roll som pedagog. Av någon benämndes det till och med som ett uppvaknande.

Eva: Ska det vara samma uppvaknanden på den då behöver vi ju minst ett halvår till (pratar om vad vi kommer att kunna se $i$ nästa aktion, det vill säga aktion 3, min anmärkning).

För att summera gruppens analys av sitt eget och barnens agerande i verksamhetsaktion 2 så visade det sig alltså att pojkarna överlag fick en mer fysisk central position i förhållande till var konstruktionen tog plats än flickorna. Ofta befann sig många av pojkarna mellan själva huset, som skulle utrustas med dörrar (som var huvudfokus i denna aktion), och flickorna. Det visade sig att en del av pojkarna aktivt forcerade sig fram till en central 
plats, även om de inte haft denna position från början, och att de i detta forcerande tryckte undan de andra barnen. Detta agerande tilläts utan några större invändningar från de deltagande pedagogernas sida, de menade att de inte ens hade märkt att detta skedde under själva aktiviteterna. Det var till och med så att vissa pojkar "bjöds in" till en central roll mellan materialet och den pedagog som för tillfället hjälpte barnen med konstruktionsarbetet. Detta skedde både hos de pedagoger som var ensamma med två barn och de pedagogpar som hade hand om fyra barn.

Deltagarnas upptäckt av att de inte riktigt agerade och bemötte barnen på det sätt de trodde att de gjorde verkade skapa en del konflikt hos dem. Denna konflikt, att det skavde mellan verklighet och uppfattning, blev tydlig i diskussionen om vad deras agerande och bemötande berodde på. Deltagarna sökte efter förklaringsmodeller till detta och var delvis inne på att det kunde bero på att verksamhetsaktionerna i sig var en något konstlad situation, där de hade haft fokus på att få uppgiften färdig för att inte förstöra för forskningen. Eller som Lena och Eva uttryckte det.

Lena: Då är det svårt för då är man så, jag vet inte om man är så fokuserad själv i...

Eva: Uppgiften

Lena: ...uppgiften så att man tappar det fokuset på just det.

De menade att om det hade varit en "vanlig" aktivitet i vardagen hade de kanske inte agerat på exakt samma sätt. Denna förklaring köptes dock inte rakt av utan skapade debatt i gruppen där det lyftes att det faktiskt kan vara så att de även i de vardagliga aktiviteterna har fokus på uppgiften i sig, och därmed agerar precis som de gjorde i verksamhetsaktion 2.

Anna: Men jag blir ju väldigt, fokus på att uppgiften ska...

Carina: Ja, precis.

Anna: Du kände så också. Eller när jag reflekterar över det efteråt, inte kanske när jag gick in i det, men när jag tänkte efteråt, det blev liksom, aha. Det var liksom det som var det viktiga för mig då ( $p r a-$ tar om att fä uppgiften färdig, min anmärkning), det blev det efteråt att jag tänkte att det var så. Och då funderar jag på, - hur ofta gör man så?

Jenny: Mm. 
Deltagarna sökte även andra förklaringsmodeller till sitt agerande och bemötande. Ofta handlade det om modeller som kan kopplas samman med undertemat aktivitetens ramar, det vill säga faktorer som befinner sig utanför den personliga sfären. En sådan förklaring handlade exempelvis om att deras sätt att agera kanske hade att göra med att barnen var positionerade på ett visst sätt vid bordet. Även dessa förklaringsmodeller ställdes dock under kritisk granskning genom debatt i gruppen, ofta utifrån att de som pedagoger då lyftes bort från problemet.
Susanne: Och det är likadant när man sitter och spelar, när man ska spela. Vi vill ju inte, vi är ju oftast inte först utan då ger man ju (ohörbart), då går man i samma ordning.
Sara: Ja, man går liksom i helcirkel.
Susanne: Ja, jag tror det, i läsriktningen och i klockan, alltså jag tror det.
Anna: Eller sitter vi här och bagatelliserar oss själva nu, att vi slä- tar över våra fel?

I slutändan blev ändå konsensus i gruppen att det faktiskt var hos dem själva och i deras personliga agerande och bemötande av barnen som det gick att hitta förklaringen. Diskussionerna slutade alltså i förklaringar som kan placeras i undertemat det personliga förhållningssättet. Exempelvis tyckte deltagarna att det var bekymmersamt att de, i en studie som handlar om teknik och genus, automatiskt utgår från att de alltid bemöter alla barn lika. De ställde sig frågande hur det då egentligen ser ut i de vardagliga situationerna på förskolan och hur de faktiskt agerar i dessa.

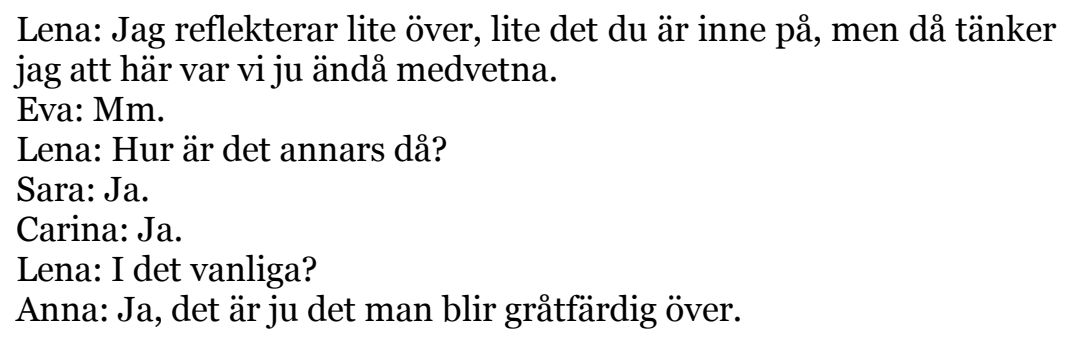

Deltagarna menade att medverkan i studien, och användandet av video som verktyg för att synliggöra sitt eget agerande, hade fătt 
dem att bli mer medvetna om att de faktiskt agerar annorlunda än vad de trott att de gör.

Lena: Det första är ju att man måste bli väldigt medveten och det blir vi ju.

Carina: Ja, precis.

Sara: Ja, vi blir ju det som sitter här.

Jenny: Ja.

Lena: För innan när man bara var med i aktionen och blev filmad så trodde man ju att man var mer rättvis eller vad jag ska säga.

Eva: Såg till.

Lena: Och såg till att alla kom till tals och att alla fick använda och alla fick göra. Men så är ju faktiskt inte.

Jenny: Så ser vi ju att det inte var.

Lena: Nä, så ser vi ju att det inte var.

Detta resultat kan ses som ytterligare ett fall som pekar på hur viktigt det är för förskolans personal att få möjlighet att observera sig själva, för att genom detta få möjlighet att reflektera över sitt eget agerande och bemötande av barnen. Deltagarna påpekade att upptäckten av att de inte agerade som de trodde att de gjorde hade fătt dem att börja reflektera över, och förändra, hur de förhåller sig till barnen i vardagssituationerna på förskolan.

Jenny: Fast jag tycker ändå att det har väckts mycket tankar och att man liksom hamnat i situationer, alltså tänker till.

Lena: Där man kanske gör faktiskt på ett annat sätt...

Jenny: Ja.

Lena: ...än vad man hade gjort innan.

Jenny: Precis.

Gruppens diskussioner pekar alltså på att utgångspunkten för förändring är att få syn på sitt eget agerande, det vill säga aspekter som kopplar till det personliga förhållningssättet. Dock menade deltagarna att en förändring, vilken slags förändring det än handlar om, inte sker i en handvändning och att det är lätt att falla tillbaka i gamla handlingsmönster. Om en förändring av det personliga förhållningssättet ska kunna äga rum måste rätt förutsättningar skapas. Deltagarna menade att de måste fă tid och utrymme att observera sitt eget beteende och möjlighet att diskutera det som observerats. 
Lena: Sen tror jag inte det är så lätt att förändra. Jag menar inte att jag är negativ till förändring men jag tror inte det är gjort på en handvändning.

Anna: Nä, det är det jag menar, det är en lång process.

Lena: Det kommer att ta...

Anna: Jajamen.

Lena: ...många filmningar och många diskussioner.

Jenny: Ja.

Exempelvis hade en av deltagarna filmat sig själv i en av de vardagliga aktionerna och sett att hon återigen agerade och bemötte barnen på liknande sätt som hon gjorde under verksamhetsaktion 2. Detta var inte något hon förväntat sig göra.

Anna: Då har jag ändå suttit, det här gjorde jag ju efter vi hade gjort alla dom här filmningarna.

Jenny: Precis, och då filmade du dig igen liksom.

Anna: Ja, och då blev det precis samma sak Jenny!

Jenny: Ja, herregud.

Även om fokus under efterarbetet med verksamhetsaktion 2 låg på aspekter av undertemat det personliga förhållningsättet så lyfte gruppen ändå förslag på förändringar inför verksamhetsaktion 3 som mer kopplade samman med undertemat organisatoriska ramar. Men nu handlade det om att förändringar av dessa ramar kunde vara en hjälp i att både belysa och förändra det personliga förhållningssättet. Utifrån verksamhetsaktion 2 förändrades alltså gruppens förståelse av det identifierade problemområdet. Dessa förändringar av de organisatoriska ramarna handlade dels om att ingen pedagog skulle arbeta ensam med två barn i verksamhetsaktion 3. Istället skulle de olika avdelningarnas verksamhetsaktioner innehålla två pedagoger och fyra barn, där den ena pedagogen hade mer fokus på den tekniska aktiviteten och den andra pedagogen hade ett större fokus på interaktionen mellan pedagog-barn och barn-barn. Deltagarna menade att även om en pedagog kan hantera en situation där ett barn tar plats på bekostnad av andra barn, exempelvis genom att barnet avbryter en konversation mellan pedagogen och ett annat barn, så innebär denna hantering i sig att fokus flyttas till barnet som avbryter. Om det istället hade funnits ytterligare en pedagog närvarande hade den personen kunnat hantera detta utan att den andra pe- 
dagogen behövt släppa fokus från det första barnet. Dels handlade förändringarna om att barnen skulle fă sitta runt ett bord med bestämda platser under nästa aktivitet och att all konstruktion skulle ske vid det bordet. Deltagarna menade att en inramning av barnens fysiska plats skulle underlätta både för dem själva och för barnen under aktiviteten. Resonemanget utgick från att den fasta platsen skulle göra att pedagogerna inte behövde "tjata" på barnen upprepade gånger att inte tränga sig före något annat barn, istället skulle de ha ett argument som barnen enkelt skulle kunna förstå.

Anna: Ja, och då blir det ju lättare för oss också, tänker jag. Att man säger, - där är din plats Jenny, och där är Carinas! För då kan inte Carina vara där för Carina plats var där, nä, jag vet inte. Jenny: Jag tror det blir bättre.

Tyvärr fanns det väldigt lite tid för uppföljning av verksamhetsaktion 3, men överlag menade deltagarna att de förändringar som gjordes hade hjälpt dem att ha ett tydligare fokus på interaktionerna under verksamhetsaktion 3 och att detta gav dem bättre förutsättningar att behandla barnen mer likvärdigt än i föregående verksamhetsaktioner. De lyfte även att förändringarna hade gjort att vissa barn inte tog utrymme på bekostnad av något annat barn på samma sätt som innan.

Sammanfattningsvis visar resultatet att när det kommer till utvecklingen av den pedagogiska ledarrollen så diskuteras denna dels utifrån aktiviteternas ramar och dels utifrån det personliga förhållningssättet. Det går att se att dessa två perspektiv av utvecklingen av ledarrollen rör sig framåt hand i hand. Å ena sidan blir inte vissa aspekter av det personliga förhållningssättet riktigt synliga förrän vissa aspekter av aktivitetens ramar förändrats. $\AA$ andra sidan kan en förändring av aktivitetens ramar användas för att belysa det personliga förhållningssättet, och därigenom skapa möjlighet till förändring. Det är just genom observation och reflektion av det personliga förhållningssättet i grupp som en förändring av den pedagogiska ledarrollen verkar kunna ske. Att pedagogerna făr tid och utrymme för denna observation och reflektion är en mycket viktig faktor i sammanhanget. 


\subsection{Innehåll som barnen får möta}

Det andra övergripande temat utgår från det ämnesmässiga stoff som hamnade i centrum i planerandet av och under själva genomförandet av verksamhetsaktionerna. Det går i resultatet att se att gruppen dels fokuserar på aspekter som har en tydlig koppling till den traditionellt sett manliga sfären av teknik. Dels går det att se att när det handlar om vad som utgör stereotypa bilder och tankar om teknik så är det i synnerhet artefaktersom används för att representera detta.

\section{Den traditionellt sett manliga sfären av teknik}

När det kommer till det första undertemat, den traditionellt manliga sfären av teknik, går det att konstatera att gruppen nådde konsensus väldigt snabbt under de första mötena angående vilken slags teknik som barnen skulle få möta i de olika verksamhetsaktionerna. Det handlade om skruvar, muttrar och gångjärn, samt några olika slags verktyg (syl, skruvmejsel, och liknande). Dessa kan kopplas till den "hårda" tekniken och bygg- och konstruktion som av tradition varit en del av den manliga sfären av teknik. Det bör påpekas att det inte gick deltagarna obemärkt förbi att det var just denna slags teknik som valdes för att synliggöra teknik för barnen. De uttryckte förvåning över av att de faktiskt väljer ett material med så pass tydliga kopplingar till den traditionellt sett manliga tekniken. De menade att utifrån utgångspunkterna att de; ett - är kvinnor; två - är förskollärare; och tre - deltar i en studie om teknik och genus, så är det intressant att fokus ändå hamnar på ett så pass manligt kodat material.

För att få en tydligare förståelse för varför just detta material valdes kan det vara intressant att titta på vad som hände under gruppens möten som ledde fram till verksamhetsaktion 1. Under dessa möten fokuserade gruppens diskussioner delvis på deltagarnas tekniksyn. För att underlätta för denna diskussion hade jag plockat med mig en rad olika artefakter och en rad olika bilder på människor engagerade i olika slags aktiviteter. Artefakterna var en t-shirt, en locktång, en konservburk, en transformersfigur (humanoid robot/bil), en skiftnyckel, en smartphone, ett resespel (Fia), en bok, ett par hörlurar, ett pingisracket, en gaffel, en strumphängare (i form av en bläckfisk), en kaffekopp, en lego- 
bil och ett batteri. Bilderna på aktiviteter föreställde män vid ett löpande band i en bilfabrik, några barn som cyklar, barn som bygger med klossar, barn som leker i en sandlåda, gatumusikanter, en hand som stryker, en kvinna som pratar i telefon, kvinnor som arbetar vid symaskiner i en textilfabrik, händer på en tvspelskontroll, en man som styr en process via en dator samt en kvinna som läser en bok. Deltagarna diskuterade utifrån dessa artefakter och aktiviteter hur de själva såg på teknik. Det gick utifrån dessa diskussioner att konstatera att deltagarna hade en mängd varierande sätt att definiera teknik. Även om flera av deltagarna uttryckte en tanke om att allt egentligen är teknik så gick det att se att det i synnerhet var vissa definitioner som lyftes fram mer än andra. Dessa skulle kunna beskrivas som elektronik, mekanik, problemlösning, färdighet, samt bygg och konstruktion det vill säga områden som av tradition går att koppla samman med den manliga sfären av teknik. Diskussionerna fick deltagarna att börja reflektera över sin syn på teknik, exempelvis ställde de sig frågande till varför de lyfte fram bilindustrin framför textilindustrin som ett exempel på en teknisk aktivitet.

Jenny: Om man tänker tillbaka på förra, jag har tänkt mycket på det efteråt, det här med bilderna, att vi valde teknik i fabriken, när de gjorde bilarna, det var den vi fastnade för flera stycken.

Eva: Mm.

Jenny: Men inte när de sydde.

Anna: Mm.

Jenny: Att det liksom, det blir manligt i det där, i fabriken med bilarna, det är lika mycket teknik när de syr. Och det tyckte jag var spännande, det är det första man tänker på, och det gjorde även jag.

Det fanns även indikationer på att diskussionerna gav deltagarna en förståelse av varför de väljer att arbeta med en viss slags teknik i aktiviteterna i förskolan, och att det kan kopplas tillbaka till deras syn på teknik och de erfarenheter de bär med sig från privatlivet. Exempelvis beskrev Anna att hon fătt en större förståelse för varför hon ofta väljer att jobba med aktiviteter som har någon slags koppling till mekanik, och även ibland till fordon.

Anna: Fast när jag sitter nu och reflekterar över vad det är egentligen jag säger och jag tänker så känner jag ju att jag har med mig, 
det spåret är ju väldigt djupt. Det jag tänker, det jag gör med barnen, så finns ju det här, att kunna röra sig, det sitter väldigt djupt hos mig. Det bara blev en sån reflektion nu när vi sitter och pratar om det.

/.../

Anna: Anledningen till att vi landade där, i den tekniken, var för att det var jag som körde igång det och jag var ju inne på, som vi såg förra gången, på kraft och rörelse. Det blev väldigt tydligt för mig varför jag landade i det.

Eva: Fick de i uppgift att skapa ett fordon, eller rita eller konstruera?

Anna: Ja, vi gjorde på olika sätt.

Eva: Mm.

Hon menade att detta egentligen inte är något konstigt med tanke på de erfarenheter och upplevelser hon har med sig. Hon beskrev exempelvis flera teknikminnen relaterade till bilar, bland annat i form av att kunna meka med sin egen bil eller att ha jobbat på bensinmack. Hon menade att hennes definition av teknik och de aktiviteter hon brukar genomföra med barnen går att spåra tillbaka till dessa och liknande erfarenheter av teknik, och att dessa även kan kopplas samman med manlighets- och femininitetsnormer.

Jag tror att det handlar mycket om spåren som jag har i mitt huvud med manligt och kvinnligt, traditionellt sådär, det man har med sig.

De spår som Anna talar om verkar inte enbart hänga samman med traditionella bilder och normer av vad som klassas som teknik utan verkar också gå att koppla till bemötande av andra i interaktionen med teknik. Flera av deltagarna beskrev erfarenheter kopplade till teknik utifrån bemötande, antingen som en positiv upplevelse i form av en triumferande känsla av frigörelse genom användandet av teknisk kunskap eller som en negativ upplevelse genom att bli bemött som okunnig på grund av att vara kvinna.

Sara: Ja, är det jag nu? Jag gjorde som Eva och slog ihop det här med genus och negativt. Det här med att bli bemött som tjej - du är tjej, kan du? Just den känslan tänker jag, som har varit intresserad och fătt hålla på - låt mig hålla på! Att inte bli stämplad för att man är tjej - ska du hålla på med sånt?

/.../ 
Anna: Och sen jobbade jag på en bensinmack också, och där var det ju vissa saker, man skulle byta vindrutetorkare om nån kom in och man skulle fylla på olja och kolla luft och lite sånt där som ingick i det här. Och där var det ju - nä, då väntar jag till Anders kommer tillbaka (pratar om en kund, min anmärkning), - nä men jag kan det här (pratar om en ung Anna, min anmärkning) - och sen att man kunde imponera på de här gamla gubbarna att man kunde byta de här vindrutetorkarna.

I dessa diskussioner upptäckte även deltagarna att de var mer inkluderande när de definierade teknik i sin roll som förskollärare gentemot när de definierade det i form av privatperson. De menade att när de befinner sig i sin roll som förskollärare så kan de inta en position där de utgår från att konstruktion i sandlådan är lika mycket teknik som konstruerandet av en bil i en bilfabrik. Om de istället går in i sin roll som privatperson är inte detta längre helt sant, då har istället bilfabriken en högre ställning som teknik.

Jenny: Alltså, jag vet inte, om man tänker lite sådär privat då tänker jag den bilden (pekar på bilden på bilfabriken) men sen helt plötsligt om jag är förskollärare då tänker jag den andra bilden (pekar på bilen med barn som bygger med klossar) (många instämmande nickningar). Om man nu kan skilja på det så det vet jag inte. Det är väl att den där (pekar på bilden på bilfabriken) sitter längre (pekar mot sin ryggrad).

Anna: Men det är det jag menar, fast jag uttryckte det med andra ord.

Lena: Det var min tanke också.

/.../

Anna: Jag tänker ändå på bilfabriken är det som jag har med mig, som ligger mest rotat i mig om man säger. Sen kan man ju tänka med sandlådan och teknik men det här är det som sitter djupaste spåren om man säger.

/.../

Sara: Mm, jag tror också att det är det som är mest djupt rotat, det andra är senare tillägnat.

Den inkluderande syn deltagarna har på teknik verkar alltså vara begränsad till förskolan som institution och deras roll som förskollärare. Det skulle naturligtvis gå att argumentera för att detta egentligen inte ställer till något problem. Så länge pedagogerna inte låter den personliga synen på teknik påverka den profession- 
ella finns ju ingen anledning att de inte kan ha två olika syner. Frågan är dock om detta inte är enklare sagt än gjort? Exempelvis uttrycker Anna att det hon väljer att göra med barnen i de tekniska aktiviteterna på förskolan tydligt går att spåra till den definition hon gör av teknik på det privata planet.

Det är det jag fastnar för, det jag kanske utmanar vidare hos barnen.

Dessutom, när gruppen inför verksamhetsaktion 3 stod inför valet att kontextualisera aktiviteten antingen med hjälp av en bil eller en lekstuga, så var det bilen som valdes. Detta kan ställas i relation till deltagarnas personliga syn på vad som framförallt räknas som teknik (där bland annat bilar fick en framträdande roll). Detta skulle kunna ses i ljuset av att det är oerhört svårt att separera den privata sfären och den offentliga, där rollen som pedagog påverkas av den privata rollen.

Trots att deltagarna under studien alltså identifierar att de gör en uppdelning där den traditionellt sett manliga tekniken positioneras på ett högre plan än den traditionellt sett kvinnliga tekniken, så väljer gruppen ändå att $\mathrm{i}$ alla verksamhetsaktionerna arbeta med just skruvar, muttrar, gångjärn och handverktyg, samt att i den sista verksamhetsaktionen välja bilen som kontext före lekstugan. Deltagarna menade att de genom att välja just detta material kan få fram intressant information om barnens förhållande till stereotyper, i synnerhet eftersom detta är ett material som inte används särskilt ofta i förskolan och att de därför saknar erfarenhet av hur barnen reagerar på det. Deltagarna påpekade också att enligt deras erfarenhet så har barn i förskolan ofta stereotypa tankar om vem som är bäst lämpad att arbeta med teknik, i synnerhet när det kommer till teknik kopplad till verktyg samt bygg och konstruktion. Gruppen menade därför att användandet av skruvar, muttrar och gångjärn som material skulle kunna ge intressant information om barnens stereotypa synsätt på teknik.

Sammanfattningsvis går det att konstatera att deltagarna menar att deras definition av teknik delvis går att spåra till deras egna tidigare erfarenheter och upplevelser i mötet med teknik. Det går 
även att se att det är den traditionellt sett manliga tekniken som făr den främsta rollen i gruppens diskussioner, och att denna teknik anses vara bäst lämpad att använda för att utmana barnens stereotypa tankar. Deltagarna menar att de i sin roll som pedagog i förskolan kan se förbi sin personliga syn på teknik och vara mer inkluderande i vad som lyfts fram som teknik för barnen. Detta är dock inte något som går att se i denna studies resultat, här verkar istället deltagarnas personliga syn spela en viktig roll.

Stereotyp teknik

En genomgående tanke i gruppen var att verksamhetsaktionerna kunde ge information om barnens potentiella stereotypa tankar om teknik. Under efterarbetet med verksamhetsaktion 1 visade det sig dock att de genomförda aktiviteterna på de olika avdelningarna gav väldigt lite information om detta. Det enda gruppen kunde se var att det fanns en tendens bland en del av barnen att koppla materialet, i synnerhet verktygen, till män i deras närhet. Överlag gick det att dra väldigt få slutsatser kring huruvida barnen hade några stereotypa tankar eller ej. Däremot kunde gruppen identifiera att de flesta av barnen visade ett stort intresse när det kom till den kontext som materialet var placerat inom, det vill säga att konstruera ett gemensamt hem till karaktärerna från böckerna om Grodan och hans vänner (för en utförligare beskrivning av verksamhetsaktion 1, se bilaga 2). Gruppen kom fram till att ett sätt att försöka identifiera stereotypa tankar hos barnen kunde vara att göra förändringar kring aktivitetens kontext - hur uppgiften ramades in för barnen. Detta skulle kunna ses som att förståelsen av problemformuleringen förändrades inför verksamhetsaktion 2. I dessa diskussioner framgår det att utgångspunkten för gruppen var inte om barnen hade dessa tankar utan hur gruppen skulle kunna locka fram dem. Dessa diskussioner låg till grund för att gruppen sedan valde att könskoda aktivitetens kontext på ett stereotypt sätt, allt för att se om detta kunde skapa en reaktion hos barnen.

När gruppen diskuterade vad för slags kontext som skulle användas för verksamhetsaktion 2 föreslog jag att vi skulle kunna hålla kvar tanken med huset från verksamhetsaktion 1. Detta gjorde 
jag beroende på att gruppen hade konstaterat att många av barnen verkade intresserade av uppdraget i föregående verksamhetsaktion - att bygga ett hus till grodan och hans vänner. De andra deltagarna tyckte att detta var en god idé och frågan blev då hur denna kontext skulle kunna könskodas på ett stereotypt sätt. I detta val spelade jag återigen en viktig roll. Under cykel 1 hade deltagarna varit inne på diskussioner om hur olika artefakters attribut kunde signalera kvinnlighet eller manlighet. En del av gruppens diskussioner under aktionsforskningens första cykel rörde sig runt vilka signaler som kan uppfattas hos ett material eller en artefakt. Det handlade generellt sett om hur utseendet och formen kan signalera något för barnen. Det var kanske först och främst artefakter som kan kopplas direkt till barnens vardag, exempelvis kläder och leksaker, som lyftes fram av deltagarna i detta resonemang, men även andra artefakter kom på tal. En vanligt förekommande diskussion under gruppens möten utgick från hur färg gör att en artefakt uppfattas som kvinnlig eller manlig. Exempelvis så pekades Brioskruvars färg ut som en förklaring till varför detta material kan tilltala även flickor. Denna tankegång blev även synlig när diskussionerna berörde "riktiga" skruvar och muttrar. Det var i synnerhet dessa artefakters yttre synliga attribut, i detta fall att de kan uppfattas som glittriga, som användes som en förklaring till varför även dessa skruvar skulle kunna intressera flickorna på förskolan.

Eva: Jag tänker om det är tjejerna som är intresserade av de silverfärgade, om det nu är silverfärgade skruvar och muttrar.

Jag ställde frågan i planeringen av verksamhetsaktion 2 om en möjlig väg att köna kontexten skulle vara med hjälp av artefakterna, vilket resten av gruppen snabbt hakade på. Gruppen diskuterade olika sätt att göra huset stereotypt kvinnligt och/eller stereotypt manligt på. De flesta av dessa idéer handlade om vilka artefakter som skulle placeras i "huset" och vilken färg artefakterna skulle ha.

Johan: Men jag började fundera på vad händer om vi helt kastar oss ut i andra riktningen? $\mathrm{Nu}$ har vi ju redan material (talar om skruvar och muttrar, min anmärkning) här som kanske faller inom den manliga sfären, vad händer om vi... 
Eva: Säger att vi ska måla det i en tjejfärg.

Johan: Eh, ja.

Sara: Då tycker jag rosa.

Det verkade finnas en förväntan hos gruppen att det i synnerhet var färgsättningen som skulle medföra att tecken på stereotypt eller icke-stereotypt synsätt hos barnen skulle gå att observera.

I slutändan kom gruppen fram till att göra huset stereotypt kvinnligt. Artefakter som av tradition har varit kopplade till kvinnor, exempelvis en spis (en modell tillverkad av mig), valdes att placeras i huset. Artefakterna gavs färger och former som ofta används inom (industri)design med en kvinnlig användare i åtanke. Att kontexten i verksamhetsaktion 2, huset och dess innehåll, fick en viss färgsättning verkar för deltagarna bidragit till att de tydligare kunde se att aktiviteten överlag nu fokuserade på genus (något som de i början av studien inte menade var helt tydligt, se exempelvis kapitel 5.1).

Lena: Men i så fall ska alla göra typ i rosa (pratar om hur huset ska se ut, min anmärkning) och sen har vi blandade grupper, killgrupp, tjejgrupp? Eller ska man utmana liksom?

Johan: På olika sätt?

Lena: Ja.

Johan: Ja, det skulle man ju kunna göra också, det skulle man kunna göra. Vi har...

Eva: Då blir det mer fokus på genus nu.

Lena: Ja, egentligen.

I efterhand går det naturligtvis att fundera på hur mycket av allt detta som egentligen handlade om någon slags projicering av gruppens egna perspektiv gällande artefakters könskodning. Det är tydligt i gruppens diskussioner att vi relaterar artefakternas attribut i förhållande till stereotyper. Exempelvis framkommer detta när vi pratar om modellerna av dammsugarna och spisarna som skulle placeras i husen.

Johan: Nä, men kan man, jag börjar fundera på om man kan köna kontexten och se vad som händer? Om vi nu har dom här, bland annat skruvar och muttrar och gångä̈rn och vad det nu är, men om vi könar kontexten, alltså dom får här 'plank' (ställer ned på bordet med händerna), så får dom ett rum och därinne är 
det jättestereotypt med, och då kanske vi får ha förberett det här rummet i såna fall, och så är det rosa väggar och det är en spis och det är en dammsugare, alltså nu är jag jättestereotyp va.

Jenny: Att det är en mamma.

Johan: Ja, eller så är det Bengt som bor där.

Sara: Mm.

Jenny: Ja, du tänker så tvärtom.

I citatet ovan kopplar exempelvis Jenny den rosa färgen, dammsugaren och spisen till att det skulle vara en mamma som bor i huset. Även om jag försöker vända på det så att det istället är en man som bor i huset så utgår ju även mitt resonemang från att denna man då skulle vara någon som bryter mot normen, och även detta pekar ju på ett stereotypt förhållande till attributen från min sida. Anledningen till att jag föreslog att det kunde vara en man som var ägare av huset baserades på att detta kanske kunde skapa motsättningar i vissa barns upplevelse av kontexten och därmed ge ytterligare information om huruvida barnen hade stereotypa tankar eller ej. Tanken var att ett motsägelsefullt könande av kontexten skulle kunna fungera som en katalysator för diskussionen mellan barnen och pedagogerna.

Deltagarna tyckte att det lät som en intressant idé med en man som ägare av huset och valde att jobba vidare utifrån detta. När det kom till mannens utseende spelade återigen artefakter, denna gång i form av kläder, en stor roll för könskodningen. Gruppen kom fram till att det bästa sättet att signalera till barnen att mannen var en "riktig man" var att använda en bild av en välklädd man i mörk kostym.

Varken husets könskodning eller den man som presenterades som husets ägare hade dock några större effekter som en katalysator för att lyfta fram potentiella stereotypa tankegångar hos barnen. Därför bestämde sig gruppen för att återigen göra förändringar inför verksamhetsaktion 3. En slutsats som gruppen drog utifrån verksamhetsaktion 2 var att när väl mannen presenterades för barnen så stängdes möjligheterna att diskutera vem som bodde i huset, det var helt enkelt "mannen" som gjorde det. Gruppen bestämde därför att flera karaktärer skulle användas under nästa verksamhetsaktion och att barnen skulle diskutera 
vem av dessa de trodde var ägare till bilen. Dessa karaktärer skulle vara inkluderande utifrån aspekter som kön, ålder och etnicitet. Gruppens idé var att använda sig av både stereotypa och icke-stereotypa karaktärer och se om detta kunde vara ett sätt att identifiera och utmana potentiella stereotypa tankegångar hos barnen. Det bestämdes att jag skulle plocka fram ett antal bilder på personer och att gruppen sedan skulle enas om cirka sex till åtta stycken som skulle ingå i nästa verksamhetsaktion. I detta arbete fick återigen artefakters könskodning en viktig roll, i detta fall handlade det om vilka attribut karaktärerna poserade med vilka slags kläder och verktyg/hjälpmedel (som kunde kopplas till ett visst yrke). Det blev i diskussionerna inför verksamhetsaktion 3 tydligt att gruppen sammankopplade vissa yrkesroller med specifika attribut hos yrkesrollsinnehavaren, till exempel gula skyddskläder för lastbilschauffören eller handverktyg för snickaren.

Anna: Då tycker jag lastbilschauffören

Eva: Ja, det tycker jag med.

Jenny: Ja, hon är mer...

Carina: Ja, hon är lättare att relatera till, för...

Jenny: ...lättare att se, ja, jobbare liksom.

Carina: Mer tydlig.

Deltagarna menade att det är just tydligheten i dessa synliga yrkesattribut som är avgörande för bestämningen av en persons yrke. Exempelvis menade de att det inte var tillräckligt tydligt att stridspiloten var just en stridspilot utifrån enbart overallen.

Eva: För mig är det inte tillräckligt tydligt att hon är typ pilot.

Deltagarna menade dock att det kan finnas svårigheter för barnen att se kopplingen mellan ett yrkesattribut och ett yrke eftersom det hänger samman med erfarenheter. Exempelvis menade de att en svetshjälm kanske istället ses som en riddarhjälm av barnen.

Carina: Mina kommer nog tro att det här är en riddare (håller upp svetsaren, min anmärkning).

Jenny: Ja.

Carina: Jag tror inte dom vet vad en svetsare är. 
Jenny: Nä.

Att barnen, och då i synnerhet de yngre barnen, hade bekymmer med att tolka människornas yrken utifrån de yrkesattribut som fanns med på bilderna visade sig sedan stämma ganska bra utifrån vad som kunde observeras i verksamhetsaktion 3.

Det visade sig i verksamhetsaktion 2 att de yngre barnen, runt 3 år, inte verkade bry sig om färgerna överhuvudtaget utan kopplade samman huset med fantasidjur eller att de själva bodde i det. Det var endast hos några av de äldre barnen, runt 5 år, som det verkade finnas någon slags stereotyp tanke kring att det rosa huset kunde kopplas till kvinnlighet. I det här fallet menade ett par av barnen att det troligtvis var en rosa barbie-liknande docka som bodde i huset. Ett liknande mönster gick sedan att observera under verksamhetsaktion 3 när den svarta sportbilen användes som kontext. För några av de äldre barnen verkade den ge associationer till traditionella bilder av manlighet men för de flesta av barnen, i synnerhet de yngre, så verkade färgen inte kopplas samman med en manlig eller kvinnlig karaktär. För dem handlade det mer om att ägaren av bilen borde vara en person med kläder i samma färg som bilen, sak samma om det var en man eller kvinna. Detta var inte ett av de möjliga sätt att koppla samman karaktärerna med bilen som vi diskuterat i gruppen före verksamhetsaktionen, utan vi hade utgått från att barnen skulle diskutera ägande utifrån kön eller yrke, vilket återigen kanske säger mer om oss och de förväntningar vi hade på barnens sätt att förhålla sig till stereotypa bilder. Inte heller karaktärernas attribut gav några solklara indikationer på att barnen såg på dessa utifrån ett stereotypt tankesätt, inte mer än att något barn i verksamhetsaktion 2 menade att eftersom mannen hade en kostym så måste det betyda att han var chef, eller som i verksamhetsaktion 3 när ett annat barn menade att den manliga sjuksköterskan måste vara en doktor. Det var återigen de något äldre barnen som uttryckte ovanstående tankar.

Under arbetet med att plocka fram stereotypa och icke-stereotypa karaktärer gick det däremot att se att vi i gruppen hade stereotypa uppfattningar gällande yrken och manlighet/kvinnlighet. 
Exempelvis som i följande meningsutbyte där vi diskuterar en manlig sjuksköterska och en kvinnlig lastbilschaufför, och att detta är något som kan tolkas som att det faller utanför normen.

Johan: Och sen har vi en svetsare (håller upp en bild på en kvinnlig svetsare), så att jag har försökt att vända lite på rollerna och så där.

Jenny: Mm.

Anna: På steken.

Precis som i arbetet med könandet av kontexten i verksamhetsaktion 2, säger kanske detta mest något om våra egna förgivettagna antaganden när det kommer till teknik och genus.

\subsection{Barnens egenskaper och karaktärsdrag}

Det tredje temat handlar om aspekter som hänger samman med gruppens syn på barnens egenskaper och karaktärsdrag i förhållande till teknik. I detta tema ingår tankar om vad som påverkar om ett barn utvecklar förståelse och intresse för tekniken samt de förklaringsmodeller som används för att beskriva grundförutsättningarna för detta.

Att konstruera för konstruerandets skull eller för en kontext Till att börja med går det att konstatera att det verkade finnas en genomgående uppfattning hos deltagarna om att pojkar och flickor agerar olika när det kommer till hur de arbetar i en konstruktionsaktivitet på förskolan. Exempelvis fanns det funderingar på att en grupp med enbart flickor kanske agerar på ett annorlunda sätt än om det är en blandad grupp eller om det är en grupp med bara pojkar.

Lena: Vad händer om vi har bara tjejer...

Eva: Ja, precis...

Lena: ...bygger dom på samma sätt?

Eva: ...den tycker jag är mest intressant faktiskt.

Lena: Eller, har vi bara killarna, bygger dom på ett visst sätt?

Deltagarna menade att de utifrån sina tidigare erfarenheter som pedagoger i förskolan hade sett indikationer på att flickor och pojkar tar sig an konstruktionsuppgifter på lite olika sätt, där 
flickorna är mer intresserade än pojkarna av utseendet på konstruktionen.

Anna: $\mathrm{Mm}$, när vi jobbade i vår teknikverkstad så delade vi också ibland, det var lite kul då för vi vuxna ville ju se om man tog sig an materialet på olika sätt. Och där flickorna var mer i det här med tyget och det mjuka, alltså att de gjorde sin bil och sen pimpade de upp den med lite rosetter och sånt där.

Deltagarnas erfarenhet var även att flickor konstruerar saker för att sedan använda dessa för lek medan många pojkar istället är intresserade av att konstruera för konstruerandets skull, i synnerhet när det kommer till de lite äldre barnen.

Lena: Fast jag kan ändå känna, om man tänker på när barnen bygger i byggen, så är min upplevelse att killarna gärna bygger för att konstruera, tjejerna konstruerar och sen leker de med det.

Susanne: Ja, precis.

Detta var dock inte något generellt beteende som kunde observeras under de olika verksamhetsaktionerna förutom vid några enstaka tillfällen. Överlag visade det sig att de flesta av barnen verkade vara mer intresserade av att konstruera för kontexten än att konstruera för konstruerandets skull, sak samma om det handlade om flickor eller pojkar.

I Susannes grupp, som bestod av fyra pojkar, i verksamhetsaktion 1 så fanns det dock två pojkar som mest verkade vara intresserade av att göra hål i papplådorna och skruva samman dem. De två andra pojkarna konstruerade istället hus åt Grodan och vännerna för att sedan leka med den, av pedagogerna, medplockade figuren (Grodan) i detta. Intressant att anmärka är att de två pojkar som högg hål i kartongerna för glatta livet och enbart ville bygga så högt som möjligt beskrevs utifrån termer av styrka och bestämdhet, av en pedagog benämndes de till och med som alfahannar.

Susanne: Precis dom här två, det är ju dom starka pojkarna i den här gruppen. Det är ju dom som liksom har, vad ska jag säga... Malin: Alfahanne. 
Gruppen gör alltså en uppdelning mellan flickor och pojkars sätt att ta sig an aktiviteter och menar att flickorna har ett tydligare behov av att sätta konstruktionsarbetet i en kontext, att de är mer intresserade av de yttre attributen av det som ska tillverkas, samt att de dessutom konstruerar med intentionen att det som tillverkas ska användas i lek. De menar att pojkar istället konstruerar för konstruerandets skull och inte behöver ha en förklaring till varför något ska konstrueras.

Genomgående i studien verkade det finnas en dubbelhet i deltagarnas resonemang av att barn har olika fokus i konstruktionsaktiviteter. Samtidigt som deltagarna diskuterar detta utifrån några slags medfödda skillnader hos flickor och pojkar så menar de att det kanske mest har att göra med samhälleliga normer. Som exempelvis i planeringen av verksamhetsaktion 1 när de diskuterade att de kanske har förutfattade meningar om vem som väljer att jobba med det valda materialet.

Jenny: Det kanske inte är killarna som väljer det.

Malin: Det är ju det som är spännande.

Eva: Nä, det är ju de normerna vi har inproppade i hjärnan.

Överlag i detta resonemang om barns fokus fanns det dock inga tydliga tecken på förändring. Under studiens gång reflekterar visserligen deltagarna över vad skillnaderna kan bero på, men utan att de egentligen kommer fram till någon ny syn på detta.

Att vara en snabbtänkt görare eller inte

I diskussionerna om barnens agerande i de olika aktionerna gick det även att utläsa att deltagarna verkade göra en uppdelning mellan att vara en snabbtänkt görare eller inte i förhållande till aktivitetens tekniska innehåll. De menade att en del barn är mer teoretiska och vill tänka ordentligt innan de ska göra något, medan andra barn är mer praktiska och kastar sig ut i görandet. I gruppens diskussioner verkade det finnas en slags föreställning där det snabbtänkta görandet mer kopplades samman med pojkar än med flickor. Detta blev tydligt i deltagarnas diskussioner om barnens förmåga att vara "problemlösare" eller "fixare". När dessa kom på tal var det mer ofta pojkar som beskrevs i dessa 
roller och det var tydligt att snabbhet i det praktiska arbetet var något som premierades.

Susanne: Jag ger bara SV (pojke på Susanne avdelning, min anmärkning) den uppgiften så fixar det, vet du.

Eva: Mm, precis.

Susanne: Det fixar han.

Detta var även något som blev synligt i efterarbetet av verksamhetsaktion 2. En förklaring som lyftes fram till varför några av pojkarna trängde sig före flickorna, kastade sig på materialet eller till och med plockade materialet ur händerna på flickorna, handlade om att de snabbt, för sig själva, hade tänkt ut en fungerande lösning på problemet.

Eva: Jamen, han tog ju ur handen på henne, men i min värld, i mitt tänk så är han ju redan färdig i sitt görande liksom.

Sara: Det är ju klart, det är ju jobbigt för dom barnen som är så färdiga, det är ju en frustration även som vuxen.

Eva: Mm, han hade ju redan löst problemet.

Att diskutera problemet och fundera på möjliga sätt att lösa detta viktas i detta fall inte lika högt av deltagarna som om barnet är en "kvicktänkt" problemlösare.

Anna: No tjafs, han gör det istället.

Sara: Prata på ni så gör jag.

Denna koppling mellan fixaren och manlighetsnormer i teknik blev även synlig på fler sätt än att det var just pojkar som beskrevs i denna roll. Exempelvis användes en manlig karaktär från populärkulturen för att beskriva fixaren.

Eva: Mm, men vi har ju nån liten Oppfinnar-Jocke.

Lena: Ett par stycken.

Ett annat sätt som detta skedde på var i form av att flickor ibland beskrevs som "den andra", det vill säga den som inte har intresse för teknik eller är teknisk. Exempelvis beskrevs några flickors intresse för Brio-mek som något som var värt att notera, att det "faktiskt" var de som ofta var framme först vid det materialet, 
eller som när gruppen diskuterade om resultatet av aktionen hade blivit annorlunda om det funnits en kvicktänkt problemlösande flicka som medverkade.

Lena: Sen tänker jag också, hade vi haft en tjej som är så kvicktänkt, hade det blivit skillnad?

Eva: Mm. Vi pratade ju om det innan.

Lena: Det vet vi ju inte, men...

Eva: Vi pratade om det innan, men hon hade ju redan varit med, kändes det som.

Värt att notera är att det i detta uttalande ser ut som att Eva menar att det på sin avdelning endast finns en problemlösande flicka.

Förutbestämda egenskaper eller påverkan av erfarenheter

Samtidigt som gruppen menade att det finns skillnader i hur pojkar och flickor tar sig an en konstruktionsuppgift så lyfte de även upp att detta kan bero på andra faktorer och inte enbart behöver hänga samman med om barnen är flickor eller pojkar. Men även i denna diskussion går det att hitta motsättningar i deltagarnas resonemang. Å ena sidan beskrev de att barnens intresse i aktiviteterna bygger på deras tidigare erfarenheter - hur väl de känner materialet, hur mycket spelutrymme de fått i hemmet, och så vidare. Samtidigt så lyfte de upp personligheten som en viktig faktor för hur barnen väljer att agera.

Eva: Ja, men jag menar även om man är den personligheten att man tycker att det är bättre att det är realistiskt, då tänker jag man kanske inte har sett det hemma.

Sara: Nä, precis.

Jenny: Nä.

Lena: Man kanske inte har erfarenheter.

Vid flera tillfällen beskrev deltagarna att barnens agerande går att spåra till att de är av en viss slags personlighetstyp och att dessa kommer med en viss slags uppsättning preferenser, bland annat i hur de väljer att ta sig an en problemlösningsuppgift. Som exempelvis i följande diskussion där deltagarna pratade om att barnen har olika personligheter och att detta påverkar hur de tar sig an 
en teknisk aktivitet - en personlighet som är intresserad av realism och en annan som är mer fantasifokuserad.

Anna: Du måste, om man tänker human dynamics så måste vi ha lite valfritt, alltså lite varierat material också... Jenny: Ja, då kan dom ha två olika.

Anna: ...så man kan få välja, det är viktigt.

Eva: ja, det är det.

Jenny: Men räcker det med två olika sorters pärlor?

Anna: Ja, och sen måste det vara något realistiskt också, det kan ju inte bara vara hejsan-svejsan.

Jenny: Det har vi ju ingenting här ju, realistiskt.

Anna: Nä, det måste vi ju ha.

Utifrån resonemangen som fördes verkar utgångspunkten vara att dessa personlighetstyper är förutbestämda. Flera av deltagarna återkommer i dessa diskussioner ofta till en utbildning de tagit del av kallad human dynamics som verkar utgå från att individer har olika så kallade grundmönster i sin personlighet, ett grundmönster som styr deras agerande. De beskriver inte bara barnen utan även sig själva utifrån tanken om olika grundmönster och att dessa mönster påverkar hur de förhåller sig till barnen och innehållet i de olika aktiviteterna.

$\AA$ ena sidan verkar deltagarna ha en bild av att dessa fasta personlighetstyper bestämmer hur individen agerar i mötet med teknik. A andra sidan lyfter de samtidigt fram att den personliga erfarenheten spelar en viktig roll för detta möte. Detta går exempelvis att se i gruppens diskussioner om varför det i synnerhet är vissa pojkar som tar en central roll i aktiviteterna och har en vilja att ta sig an verktygen och materialet. Här lyfts erfarenheter från hemmet fram som en viktig faktor.

Lena: Jamen, varför gör dom det då? Är det för att dom är intresserade eller är det för att dom vill vara först eller är det nånting annat? Är det för att dom har gjort det förut och dom tycker att dom kan, dom har en erfarenhet?

/.../

Eva: Och där tänker jag att det handlar mycket om vad man får med sig, alltså vilka erfarenheter får jag själv vara med om. 
Deltagarna menade att även om de inte vet hur det ser ut i de olika barnens hem så kan en möjlig förklaring vara att pojkarna får prova på att använda den slags teknik som ingick i studien i en annan utsträckning än flickorna.

Sara: Får pojkar prova mer hemma än flickor?

Eva: Jag vet inte, men det var dom som kände igen verktygen.

Detta var något gruppen tyckte sig kunna se tecken på i observationerna av verksamhetsaktionerna då det bland annat framgick att det i synnerhet var pojkarna som tydligast kände igen verktygen. Deltagarna kopplade även samman detta med det faktum att det var pojkarna som var snabbast med att relatera verktygen och materialet (skruvarna och muttrarna) till män i sin närhet (pappa, morfar, etcetera).

I gruppens resonemang om barnens erfarenheter av teknik framkom också en syn om att de erfarenheter som barnen har med sig hemifrån riskerar att krocka med de erfarenheter personalen på förskolan försöker att ge barnen. Resonemanget utgick från att det förmedlas två olika bilder av teknik för barnen, en stereotyp och en icke-stereotyp. De menade att hemmen och det omgivande samhället förmedlar en bild av traditionella könsroller, och trots att förskolan försöker ge barnen icke-stereotypa erfarenheter är deras möjligheter att påverka begränsade.

Lena: Det dom liksom får till sig.

Eva: Mm, det är ju så, jag tänker dom bygger ju den på egna erfarenheter.

Jenny: Mm.

Lena: Ser man ingenting annat så är det ju den världen som finns.

Eva: Vi är ju en del av den...

Johan: Ja.

Malin: Då är det väl att vi måste...

Eva: ...sen är det ju resten-resten, och det är väl där liksom...

Jenny: Det är där grunden läggs på nåt sätt.

Eva: ...den här resten-resten är ganska majoritet.

Jenny: Ja, det tror jag också.

Eva: Men vi måste ju ändå jobba på ett sätt som gör att vi känner oss nöjda med det vi förmedlar.

Johan: Ja, absolut.

Eva: Sen om inte vi rår på den biten där utanför, vi kan ju inte... 
Kapitel 5

Malin: Nä, vi kan ju inte.

Eva: Faktiskt inte göra så mycket åt det...

Malin: Nä.

Eva: ...mer än att förhålla oss till det.

Deltagarna verkar alltså utgå från att förskolan som institution är en plats som inte är lika stereotyp gällande normer som resten av samhället. Även här går det att se att deltagarna förhåller sig till barnens förståelse av teknik som något som kan påverkas av individens erfarenheter.

Sammanfattningsvis visar detta övergripande tema på att deltagarna utgår från ett synsätt där barnens intresse för teknik och agerande i interaktionen med teknik, både förklaras utifrån att det beror på medfödda egenskaper och att det är något som påverkas av livserfarenheter. I dessa diskussioner kategoriseras barnens förhållande till tekniken delvis utifrån deras roll som flicka eller pojke. 
Kapitel 6

\section{Diskussion och slutsatser}

I följande kapitel kommer jag först att diskutera resultatets tre övergripande teman var för sig. Jag kommer i dessa tre delkapitel att analysera möjligheter och utmaningar i förskolans arbete med teknik och genus utifrån det didaktiska resonemang som framkommit i resultatet. Jag avslutar kapitlet dels med att binda samman gemensamma trådar från dessa tre diskussioner och dels med att ge förslag på fortsatt forskning.

\subsection{Pedagogens roll i organiseringen av aktiviteterna}

I detta första delkapitel kommer jag att diskutera de upptäckter och reflektioner som gjordes av deltagarna i gruppen i förhållande till deras roll som pedagog, deras ledarroll, i de tekniska aktiviteterna. Detta var upptäckter och reflektioner som verkade ligga till grund för att de började att ifrågasätta vissa av sina förgivettagna antaganden om sig själva och sitt eget agerande. För att belysa dessa skeenden i gruppens diskussioner har jag tagit avstamp i Illeris (2007, 2014a, 2014b) modell för transformativt lärande. Jag har i detta arbete analyserat upptäckterna och reflektionerna i förhållande till preference layer och personality layer.

De faktorer som i resultatet kunde identifieras vara viktiga för deltagarnas diskussion, reflektion och analys av sin roll som pedagog gick att dela in i två olika kategorier. Det handlade dels om faktorer som kan sägas vara kopplade till ramarna för aktiviteten och dels om faktorer som var av en mer personlig karaktär, där deltagarnas agerande och förhållningssätt hamnade i fokus. Det blev tydligt i studien att dessa kategorier gav olika slags gensvar hos deltagarna. När faktorer som kopplade till aktivitetens ramar diskuterades i gruppen så verkade inte detta bidra till att deltagarna ifrågasatte sina förgivettagna antaganden i samma utsträckning som när deras personliga agerande och förhållningssätt i aktiviteterna belystes. Exempelvis skapade inte förändringen av antal barn per pedagog några större motsättningar eller diskussioner i gruppen. Inte mer än att deltagarna tyckte att de 
utifrån sin yrkeserfarenhet borde ha insett att det inte kunde vara en ensam pedagog med fyra barn. Att ta med detta i planeringsarbetet av kommande verksamhetsaktioner var inget som stötte på något större motstånd eller ställdes under ytterligare granskning, utan alla deltagare rättade sig snabbt efter detta och ansåg att det var en enkel förändring att göra. Denna slags förändring skulle kunna ses utifrån att det inte är något som direkt kräver att deltagarna förändrar hur de agerar och bemöter barnen i aktiviteterna, utan det räcker egentligen med att de har det i åtanke vid planeringen av aktiviteten. Denna förändring resulterade alltså inte i någon större debatt eller verkade direkt "skava" med deltagarnas syn på sig själva som pedagoger. Denna förändring skulle kunna ses som att den i grund och botten handlar om att förändra ett vanemässigt förhållningssätt i vardagen (jfr. med Illeris, 2007, och beskrivningen av preference layer). Andra faktorer som hör till kategorin aktivitetens ramar, exempelvis olika roller för pedagogerna och fasta positioner för barnen, skapade dock något större diskussioner i gruppen, i synnerhet den senare. Att aktivitetens två pedagoger kunde inta varsin roll, en som hade hand om uppgiften och en som hade fokus på samspelet, var inget som sågs som något direkt uppseendeväckande i gruppen, och inte heller något som deltagarna ansåg vara svårt att anpassa sig efter. Däremot var det ingen av deltagarna som uttryckte att de hade funderat i dessa banor tidigare. Att inta olika roller under en aktivitet verkade även det mest koppla samman med preference layer och det vanemässiga beteendet. Deltagarna beskrev att detta handlade om att, i planerandet av en aktivitet, helt enkelt förändra hur de "brukar" göra. Det visade sig dock att denna vanemässiga förändring inte var lika lätt att göra i praktiken för alla. Några av deltagarna menade att när de väl befann sig i aktiviteten hade det känts mer naturligt att inta sina normala roller och tillsammans ansvara för allt. Detta skulle kunna ses som att även det vanemässiga agerandet, som egentligen kanske inte har så stor betydelse för pedagogens syn på sig själv, kan vara svårt att förändra, alternativt att vissa av deltagarna egentligen inte såg någon motivering till att göra denna förändring. Det ska tilläggas att de pedagogpar som hade genomfört förändringen med bestämda roller menade att detta hade gett önskat resultat och 
hjälpt dem att ge mer likvärdiga förutsättningar för barnen i aktiviteten.

Att förändra till fasta positioner för barnen var däremot en förändring av aktivitetens ramar som skapade en del motsättningar i gruppens diskussioner. Deltagarna menade att de ibland, i vardagsaktiviteter på förskolan, varit för tillåtande när det kom till interaktionen barnen emellan och att de därför mer aktivt behövde arbeta med att förhindra att vissa barn tar utrymme på bekostnad av andra barn. Detta var dock inte en problemfri slutsats, deltagarna menade att denna lösning innebär att de behöver ta en mer auktoritär roll, vilket verkade "skava" med deras bild av förskollärarens professionella identitet. Dessa diskussioner skulle kunna ses utifrån att de medförde att deltagarna började ifrågasätta några av sina förgivettagande om hur de bör agera som förskollärare i interaktionen med barnen, vilket i sådana fall skulle kunna placeras mer som en förändring kopplat till personality layer.

Det som i slutändan verkade vara de viktigaste diskussionerna för deltagarnas utmanande av sina förgivettagna antagande gick dock att finna i de faktorer som kunde placeras i kategorin personligt förhållningssätt. Dessa faktorer handlade om deltagarnas upptäckter av sitt eget agerande och bemötande av barnen i de inspelade verksamhetsaktionerna, och att det som observerats inte stämde överens med den bild de hade av sig själva. I början av studien menade deltagarna att de alltid behandlar alla barn på förskolan likvärdigt. Deltagarna visade alltså upp samma slags synsätt som observerats av Eidevald (2009) och som även lyfts fram i rapporten Den Könade Förskolan (SOU 2004:115). Detta synsätt bygger på resonemanget att förskolan som institution automatiskt utgår från det individuella barnets perspektiv och att pedagoger i förskolan därigenom alltid ger flickor och pojkar samma möjligheter, rättigheter och skyldigheter. Pedagoger i allmänhet utgår alltså från att de i verksamheten agerar jämställt även om så sällan är fallet (Eidevald, 2009). Under studiens gång upptäckte deltagarna att de inte gav pojkarna och flickorna i aktiviteterna samma förutsättningar. Exempelvis kunde de konstatera att det fanns en tendens att de "tillät" pojkarna att tränga sig 
före i aktiviteterna, eller att de under konstruktionsarbetet vände sig mot pojkarna först. De kunde också identifiera att de hade olika förväntningar på barnens förmågor att hantera verktygen, där de tillskrev pojkarna mer självständighet i användandet av verktygen. Detta agerande stämmer överens med ett särskiljande av barnen där pedagoger lyfter fram vissa barn framför andra genom att ge dem bekräftelse, uppmärksamhet och utrymme (Se exempelvis Månsson, 2000 och Ärlemalm-Hagsér \& Pramling Samuelsson, 2009).

Upptäckterna av det egna agerandet och bemötandet bidrog till att deltagarna började att kritiskt reflektera, granska och diskutera det förgivettagande de hade haft i början av studien om att de alltid såg till att ge samma förutsättningar till barnen i aktiviteterna på förskolan. Det lades betydligt mer kraft och energi i gruppen på att diskutera dessa frågor än vad som lades på de diskussioner som rörde aktivitetens ramar. Dessa diskussioner verkade dessutom ge resonans på ett djupare känslomässigt plan hos deltagarna. Dels pratade deltagarna om dessa upptäckter som uppvaknanden och dels var det tydligt att upptäckterna verkade "skava" mot den bild de hade av sig själva. De alternativa tolkningar som lyftes fram av vissa av deltagarna som förklaringsmodeller till agerandet kan användas för att belysa detta "skav". Istället för att kritisera sitt eget agerande försökte en del av dem hitta svar till beteendet i aktivitetens ramar. Exempelvis som när en av pedagogerna funderade på om förklaringen till varför hon först vände sig till pojkarna i en av aktionerna kunde bero på att de satt till vänster om henne och hon helt enkelt utgick från turordningen i vanliga sällskapsspel. Detta skulle kunna ses som att deltagarna försökte hitta svar som låg mer i sfären av vanemässigt agerande än något som fanns rotat i deras identitet. I slutändan pratade dock deltagarna i termer av att deras agerande måste ses utifrån generella strukturer där de faktiskt inte ger flickor och pojkar samma förutsättningar i aktiviteterna. De uttryckte exempelvis att de efter dessa diskussioner i gruppen kunnat identifiera liknande agerande hos sig själva i andra situationer på förskolan. 
Sammanfattningsvis går det att konstatera att deltagarna under aktionsforskningsprocessen förändrade hur de såg på både aktiviteternas ramar och det personliga förhållningssättet. Förändringar kopplade till kategorin aktivitetens ramar går att hitta både inom preference layer och personality layer, där vissa förändringar inte verkade skapa något direkt "skav" överhuvudtaget, de handlade mer om ett oreflekterat vanemässigt beteende, medan andra skapade "skav" till viss del. Observationerna och reflektionerna av aktivitetens ramar verkade dock kunna hjälpa till att synliggöra det personliga agerandet och bemötandet i aktiviteterna med barnen, och därigenom ge deltagarna en djupare förståelse av sitt personliga förhållningssättet. Upptäckterna kring det personliga agerandet i aktiviteterna och bemötandet av barnen verkade däremot skapa ett större "skav" med deltagarnas syn på sig själva i rollen som pedagog.

Det verkade som att det i vissa fall räckte för deltagarna att diskutera sina erfarenheter av verksamhetsaktionerna för att de skulle börja fundera på hur aktiviteternas ramar skulle kunna förändras. När det däremot kom till det personliga förhållningssättet var videomaterialet a och o. Det var inte förrän gruppen konfronterades med videomaterialet som det blev tydligt för alla att den bild de haft av vad som hände under aktionen, att alla barn deltog på lika premisser, inte riktigt stämde överens med vad som faktiskt skedde. Det var först då som deltagarna tydligt började reflektera över och kritiskt granska sig själva. Enligt Illeris (2014a; 2014b) så måste det finnas tydliga orsaker för att en förändring av djupare personliga förhållningssätt och förgivettagna antaganden ska äga rum. En viktig slutsats som går att dra av denna studie är alltså att det kan vara svårt för pedagoger att hitta dessa orsaker om deras agerande inte först ställs under observation. Detta kan jämföras med Eidevalds (2009) resultat som pekar på att det inte räcker med att enbart diskutera det egna agerandet och bemötandet av barnen, detta måste även synliggöras för att förändring ska kunna äga rum. 


\subsection{Innehåll som barnen får möta}

I detta delkapitel kommer jag, utifrån teknikens genuskodning, att analysera den teknik som gruppen valde att fokusera på i de olika verksamhetsaktionerna. Jag kommer även att analysera hur denna teknik valdes att presenteras för barnen.

Deltagarna verkade, precis som stora delar av resten av samhället, utgå från en bild av teknik där den traditionellt sett manliga tekniken lyfts fram som just teknik och där den traditionellt sett kvinnliga tekniken inte făr samma position (Berner, 2003a; Nyberg, 2003). Exempelvis beskrev deltagarna att om de tvingades att välja mellan biltillverkningsprocessen och textiltillverkningsprocessen som en representation av teknik så var det den förra processen, med starka kopplingar till den "hårda" industrisektorn, som bättre stämde överens med deras inre bild av teknik. Detta trots att deltagarna verkade vara medvetna om att processerna i sig är väldigt lika i form av att avancerade maskiner används och styrs av människor för att tillverka en produkt som ska uppfylla önskemål och/eller lösa problem. Det gick i gruppens diskussioner, samt i planerandet och genomförandet av aktiviteterna, att se att det är just teknik som av tradition kopplats samman med den manliga sfären av teknik - exempelvis elektronik, mekanik, problemlösning, bygg och konstruktion - som fick representera teknik för deltagarna. Detta stämmer överens med vad som har rapporterats i tidigare forskning om hur pedagoger ser på teknik (se exempelvis Jarvis \& Rennie, 1998; Siu \& Lam, 2005; Sundqvist et al., 2015). Det gick även att se att gruppen fokuserade på att det i synnerhet var flickorna som behövde introduceras för, och därmed bli mer intresserade av, den manliga tekniken - det vill säga samma slags fokus på det”otraditionella" valet som kunnat ses inom forskning och politiska incitament angående teknikämnet i skolan (Berner, 2003b; Hedlin, 2009).

Även om deltagarna uttryckte att de i sin roll som pedagoger kan inta en mer inkluderande hållning till vad som kan anses vara teknik, så gick det att se att den manliga tekniken i slutändan ändå fick en högre ställning även i den kontexten. Detta blev synligt både genom deltagarnas beskrivning av de tekniska aktiviteter de tidigare genomfört på förskolan och i de olika verksam- 
hetsaktioner gruppen planerade under studiens gång. När vi i gruppen skulle välja material och uppgifter som barnen skulle få möta under verksamhetsaktionerna så var det just den traditionellt sett manliga tekniken som användes, detta trots att vi identifierade att detta material hade en tydlig koppling till den manliga sfären av teknik. Detta skulle kunna tolkas som en del i en övergripande struktur där kopplingen mellan den manliga identiteten och teknik inte ifrågasätts utan helt enkelt tas för given (Faulkner, 2001, 2003; Mellström, 2003; Nissen, 2003; Wajcman, 1991). I diskussionerna av den teknik som skulle synliggöras för barnen går det även att hitta spår av att vi i gruppen delvis utgick från män och kvinnor som homogena grupper. Exempelvis belyste deltagarna i denna diskussion valet av manligt kodade artefakter utifrån sig själva som en del av grupperingen kvinnor - att det faktum att de är kvinnor gör valet mer uppseendeväckande än om det hade gjorts av en grupp män. Det verkade dessutom i deltagarnas diskussioner finnas en underliggande tanke om att deras val av material, som förskollärare i allmänhet och som förskollärare involverade i en studie med fokus på teknik och genus i synnerhet, per automatik borde resultera i aktiviteter som förmedlar en bredare bild av teknik för barnen. Viktigt att tänka på i detta sammanhang är dock att förskolan som institution inte är frikopplat från det övriga samhället och att deltagarnas roll som pedagoger inte är något som är friställt från deras erfarenheter och roller som privatpersoner. Ytterligare något som kan ha inverkat på deltagarnas val att lyfta fram just manligt kodade artefakter är att en del av dem beskrev att de själva haft erfarenhet av att ha känt sig stärkta genom att ta sig an och kunnat hantera den traditionellt sett manliga tekniken.

Även om teknikens kontext fick en större roll under verksamhetsaktion 2 och 3 jämfört med verksamhetsaktion 1 så spelade teknik i form av artefakter en viktig roll genom hela studien. Både skruvarna, muttrarna och gångjärnen, samt de verktyg som valdes, är artefakter som traditionellt sett kopplats samman med vardagssysslor utförda av män. Materialet har dessutom en tydlig koppling till hantverksyrken som av tradition har varit hemmahörande i den manliga sfären, och vars yrkeskår till stora delar varit, och fortfarande är, uppbyggd av män (se Statistiska 
centralbyrån, 2016). Detta är en sfär där normer kring teknik mycket tydligt kopplats samman med manlighet (Mellström, 2003; Wajcman, 1991). Även om deltagarna under förarbetet med verksamhetsaktion 1 menade att de tekniska aktiviteterna i förskolan bör handla om att synliggöra vardagsteknik för barnen så var det i synnerhet frågor om vilka slags artefakter som skulle ingå i verksamhetsaktionerna som diskuterades. Detta skulle kunna tolkas som att deltagarna har en syn på teknik där det först och främst är artefakterna som får agera representant för teknik, vilket ligger i linje med Sundqvists et al. (2015) resultat gällande svenska förskollärares syn på teknik. Vilken kontext artefakterna skulle placeras i, och strukturen på de aktiviteter som skulle genomföras med barnen, fick inte samma framskjutna roll. Det verkar alltså som att gruppen placerar artefakterna på en högre position än den kontext, de vardagssituationer, som de ingår i. Även denna utgångspunkt kan kopplas till den traditionella bilden av teknik. Historiskt sett har sällan teknikens holistiska perspektiv stått i centrum inom tekniska yrken och utbildningar, fält som dominerats av män (Faulkners 2001, 2003; Berners, 2003c). Även när kontexten fick ett större utrymme, som i verksamhetsaktion 2 och 3, var det fortfarande artefakterna som hade den mest framskjutna rollen i arbetet med att försöka synliggöra barnens eventuella stereotypa synsätt på teknik.

När det handlade om att köna aktiviteten så var det i synnerhet artefakters genusprägling, deras koppling till maskulinitets- och femininitetsnormer, som lyftes upp av gruppen. Diskussionerna berörde både artefakter utifrån ett symboliskt perspektiv, det vill säga att artefakter har en lång tradition av att vara sammankopplade med vardagssysslor utförda av antingen män eller kvinnor, och ur ett materiellt perspektiv, det vill säga att olika artefakters egenskaper kan designas med en kvinnlig eller manlig användare i åtanke (Faulkner, 2001; 2003). Deltagarna beskrev att utifrån deras egen erfarenhet använder barn i förskolan ofta en artefakts utseende, exempelvis dess färg, för att avgöra om den är designad att användas av pojkar/män eller flickor/kvinnor. Men det visade sig att även för oss vuxna i gruppen så spelade artefakters utseende en viktig roll i hur vi förhöll oss till teknik, exempelvis utgick gruppens diskussioner utifrån ett resonemang som byggde 
på att färgen på materialet är viktigt för att det ska tilltala flickorna.

Deltagarna påpekade att de under sina karriärer sett att många barn (och vårdnadshavare) ofta intar ett stereotypt förhållningssätt till artefakter och aktiviteter. Utifrån detta frågade jag dem om en möjlig väg framåt kunde vara att "köna" aktiviteten, vilket de tyckte lät som en intressant fortsättning. Vi samtalade om detta utifrån att det skulle kunna vara ett sätt att fă fram information om huruvida barnen hade stereotypa eller icke-stereotypa sätt att se på teknik, och att detta skulle kunna användas för att konstruera aktiviteter där barnen inte blir begränsade av traditionella könsroller. Resonemanget utgick från tanken om att ett motverkande av stereotypa strukturer bygger på att det är viktigt att först identifiera hur barnen själva resonerar kring dessa strukturer. Efter detta skulle det sedan gå att utarbeta metoder för att ge bättre förutsättningar för alla barn att bli intresserade av teknik. Utifrån gruppens diskussioner går det att se att vi tänker oss att könandet främst kan ske genom artefakterna, och då i synnerhet med hjälp attribut som exempelvis färg. I slutändan verkade detta fokus på artefakternas symboliska och materiella genusprägling mest säga något om vad vi i gruppen hade för slags stereotypa tankar om teknik. Exempelvis förutsatte vi att ett hus med rosa dammsugare och en man i svart kostym bör skapa motsättningar i barnens tankar. Andra exempel var när vi diskuterade hur en manlig sjuksköterska och en kvinnlig lastbilschaufför kunde ses som något som faller utanför normen, eller när bilen valdes som kontext framför en lekstuga. En förklaring till det sistnämnda skulle visserligen kunna vara att lekstugan låg alldeles för nära huset som koncept och att eftersom inte huset gav några svar på om det fanns stereotypa tankar hos barnen så skulle inte heller lekstugan att göra det. Å andra sidan skulle en annan förklaring kunna vara att gruppens egna erfarenheter av bilar kopplat till teknik och manlighet spelade in. Som tidigare beskrivits lyfte deltagarna upp bilfabriken som ett tydligt exempel av deras inre bild av teknik, de kopplade även bilar och motorfordon till sin egen uppväxt och beskrev det som en del av deras erfarenheter av teknik. 
I kontrast till detta så kopplade få av barnen artefakterna, och deras attribut, till maskulinitetsnormer och/eller femininitetsnormer, även om det fanns tecken på stereotypa utgångspunkter hos en del av de äldre barnen. Att försöka locka fram eventuella stereotypa tankar hos barnen med hjälp av artefakter verkar överlag inte vara särskilt effektivt. Varken artefakterna i sig eller den kontext de placerades i, exempelvis i den tänkta motsättningen av ett stereotypt kvinnligt kodat hus och en stereotypt manligt kodad karaktär, fungerade som en katalysator för att synliggöra barnens tankar. Ett potentiellt problem med att genuskoda materialet och kontexten på detta sätt är att det löper risken att måla upp en bild för barnen som istället verkar konserverande för traditionella könsroller. Kritik har framförts att användandet av könstereotypa exempel i slutändan kan leda till att sagda stereotyper återskapas. Faulkner (2001, 2003) menar till exempel att artefakter i sig, sak samma om de är symboliskt eller materiellt genuskodade, bidrar till att konservera rådande förhållande. Sedan finns också problematiken med att ett för stort fokus på artefakter kan leda till att både vuxna och barn har svårigheter att överblicka de tekniska system som artefakterna är en del av, även om de har en god förståelse av artefakterna i sig (se Mawson, 2010; 2013 och Siu \& Lam, 2005). En risk med att fokusera tekniken som artefakter är att den politiska, sociala och ekonomiska sidan av tekniken då inte blir synlig för individen (Berner, 1999).

Sammanfattningsvis säger kanske gruppens val att lyfta just artefakter som teknik och vårt arbete med att köna artefakterna och kontexten mest något om våra egna förgivettagna antaganden när det kommer till teknik och genus. Det är framförallt i våra diskussioner som tekniken delades upp i manlig och kvinnlig teknik, inte i barnens. Det var vi som valde att inte ge den holistiska sidan av teknik lika stort utrymme som teknik som artefakter, det var vi som i diskussionerna utgick från att de könskodade artefakterna skulle skapa en motsättning hos barnen. Det går även att konstatera att gruppen utgick från ett synsätt där det framförallt är flickorna som ska hjälpas att förändra sin syn på teknik.

Även om aktionerna, både verksamhetsaktionerna och mötesaktionerna, var ett viktigt verktyg för att ge deltagarna utrymme 
för att reflektera över sin syn på teknik, så gav de väldigt få ledtrådar till vilket teknikinnehåll som kan användas i aktiviteter för att på bästa sätt motverka stereotyper kring teknik.

\subsection{Barnens egenskaper och karaktärsdrag}

I detta delkapitel kommer jag att diskutera de olika sätt, ofta motstridiga, som deltagarna beskrev barnen utifrån. Det handlar i synnerhet om på vilket sätt som barnens intresse och förutsättningar beskrevs i förhållande till egenskaper och karaktärsdrag, och som delvis gick att koppla till om barnen var flickor eller pojkar.

Motstridigheterna i diskussionerna utgick till mångt och mycket utifrån en bild av barnen som individer kontra en bild av barnen som en del av en generell gruppering, det vill säga individnivån kontra den strukturella nivån. Deltagarna växlade mellan att å ena sidan mena att en individs intresse för teknik är formbart, för att sedan beskriva barnen utifrån en tanke om en fast personlighet som, om inte omöjlig, i alla fall är mycket svår att förändra. Den fasta personligheten blev i synnerhet tydlig när diskussionerna kretsade kring specifika individer, medan det formbara intresset mer fokuserades när barnen diskuterades utifrån generella grupperingar. I förklaringsmodellerna av den formbara individen lyftes tankar om att en individ påverkas av sitt sociala sammanhang och de samhälleliga förväntningar som ställs på denne, exempelvis utifrån maskulinitets- och femininitetsnormer. Deltagarna menade att detta går att koppla samman med de upplevelser individen fått med sig under sin uppväxt, bland annat från hemmet, men också från förskolan och andra samhälleliga instanser, reklam och olika medier. De menade att från det att barn är små så formas de av sin omgivning, exempelvis genom vuxenvärldens kategorisering utifrån vad som anses vara manligt och kvinnligt. Barns intresse och förhållande till teknik går alltså utifrån detta resonemang att påverka och förändra. Detta synsätt ligger i linje med vad många andra studier visat. Det vill säga att barn i tidig ålder, utifrån en medvetenhet om samhällets sätt att kategorisera utifrån motsatsparet manlighet/kvinnlighet, lär sig vad som är passande agerande, passande aktiviteter, passande 
leksaker, passande yrken, etcetera, för kvinnor respektive män (Browne, 1991; Kimmel 2000; Lyon, 1991; MacNaughton, 1997; Månsson, 2000; Trepanier-Street \& Romatowski, 1999; Turja et al., 2009). Parallellt med detta beskrev gruppen barnen utifrån en tanke om att agerandet och intresset inte är kopplat till individens möte med samhälleliga förväntningar utan att detta beror på en slags grundpersonlighet med bestämda och fasta egenskaper. Detta synsätt utgick från att dessa egenskaper avgör en individs sätt att agera i olika situationer. Individens erfarenheter verkar utifrån detta synsätt inte spela så stor roll. Deltagarna verkade i mångt och mycket basera detta sätt att se på individers agerande utifrån en fortbildning de genomfört kallad human dynamics där människor kategoriseras utifrån olika personlighetstyper.

I sina diskussioner om barnens intresse för teknik och agerande i tekniska aktiviteter gjorde deltagarna även skillnad i hur flickor respektive pojkar beskrevs. Gruppens diskussioner kring barnens intresse (eller ointresse) för den kontext som den tekniska aktiviteten var placerad i kan användas för att belysa detta. Deltagarna gjorde delvis en uppdelning mellan flickors och pojkars sätt att ta sig an aktiviteter med fokus på konstruktion och problemlösning. De menade att flickor generellt sett har ett tydligare behov av att sätta konstruktionsarbetet i en kontext, att de är mer intresserade av de yttre attributen av det som ska tillverkas och att de dessutom konstruerar med intentionen att det som tillverkas ska användas i lek. De menade att många pojkar istället konstruerar för konstruerandets skull och inte behöver ha en förklaring till varför något ska konstrueras. För pojkarna är konstruktionen, handhavandet och sammanfogandet av material ett mål i sig, medan för flickorna handlar det om att konstruera för ett tydligt syfte. Det ska påpekas att gruppen även menade att både flickor och pojkar kan vara intresserade av kontexten, men när det handlar om att endast vara intresserad av konstruerandet i sig var det bara pojkar som lyftes fram i denna roll. Detta kan jämföras med Ärlemalm-Hagsér och Pramling Samuelssons (2009) beständighet, det genusmönster som kunnat observeras i förskolans aktiviteter där pedagogerna utgår från stereotypa synsätt i sina förväntningar på vad som intresserar flickor respektive pojkar. 
Deltagarna beskrev även barnen utifrån uppdelningen av att vara en snabbtänkt görare eller ej. Det var i synnerhet pojkar som användes i gruppens diskussioner som exempel på de snabbtänkta görarna. Det gick att se att ett praktiskt handlag av artefakter och en kvicktänkt initiativförmåga oftare belystes genom att det kopplades samman med manlighet. Även om det inte var så att flickorna helt beskrevs som motsatsen till detta så var det sällan som de användes som exempel för att beskriva de innovativa barn som är snabba med att plocka fram lösningar på ett problem. I de fall flickorna lyftes fram i dessa sammanhang beskrevs de mest i form av att de har förståelse för uppgiften men kanske inte lika bra förståelse för handhavandet av artefakterna. När flickorna väl diskuterades utifrån att vara en görare så skedde det ofta med undertoner av att det är något som faller lite utanför ramen. Detta skulle kunna förklaras utifrån den samhälleliga bilden där ett tekniskt kunnande och ett tekniskt handlag ofta jämställts med manlighet (Berner, 2003a; Mellström, 2003, Oldenziel; 1999) och där bilden av den tekniskt kompetente mannen historiskt sett följts av bilden av den mindre tekniskt kompetenta kvinnan (Mellström, 2003; Nissen, 2003; Wajcman, 1991). Även i dessa diskussioner gick det att finna spår av tankarna om den fasta personliheten och det formbara intresset. I diskussionerna beskrevs pojkars sätt att förhålla sig till, och agera i, tekniska aktiviteter i termer av att de är aktiva, tävlingsinriktade och/eller målinriktade. Samtidigt som detta agerande kopplades samman med tanken om en fast personlighet så lyfte deltagarna också vuxenvärldens bemötande av barnen utifrån kön som en viktig påverkansfaktor. Exempelvis menade de att pojkar överlag får mer utrymme och uppmuntran att interagera med teknik i hemmet och då i synnerhet med den traditionellt sett manliga tekniken.

Sammanfattningsvis går det att konstatera att deltagarna pendlade mellan att beskriva barnens agerande och intresse för teknik utifrån att det formas av barnets möte med samhället, samtidigt som det är bestämt utifrån personligheten; det formas av barnens erfarenheter, samtidigt som det beror på det biologiska könet. Oavsett vilken utgångspunkt som deltagarna använde sig av så 
beskrev de barnens agerande i aktiviteterna utifrån manlighetsnormer av teknik där exempelvis styrka och praktisk handlingskraft spelade en central roll (se exempelvis Mellström, 2003; Nissen, 2003; Wajcman, 1991). Att förskollärare kan inta motstridiga positioner i sitt synsätt på genus har konstaterats i tidigare studier (Eidevald, 2009). Denna studie pekar på att detsamma även kan gälla för förskollärares syn på kopplingen mellan teknik och genus. Dessa motstridiga positioner blev dock inte synliga förrän i efterarbetet av studien, det vill säga efter att alla mötesaktioner och verksamhetsaktioner var genomförda, och var därför aldrig uppe för reflektion och kritisk granskning under gruppens möten.

\subsection{Utmaningar och möjligheter}

I detta avslutande delkapitel kommer jag att sammanfatta analysen av gruppens didaktiska resonemang och beskriva vilka utmaningar och möjligheter dessa pekar på i förhållande till förskolans arbete med genus och teknik. Jag kommer även att diskutera slutsatserna i förhållande till fortsatt forskning.

Till att börja med är det viktigt att påpeka att jag inte sitter inne med svaren på hur de utmaningar som identifierats genom denna studie ska lösas. Jag försöker dock i texten nedan ge förslag på vad som skulle ha kunnat hjälpa till att fördjupa gruppens diskussioner under verksamhetsaktionerna. Dessa förslag ska ses mer utifrån perspektivet av fortsatt forskning än som ett recept på hur problemen ska lösas. Att arbeta med att utmana stereotyopa könsroller och könsmönster i verksamheten, som anges i läroplanen, är ett oerhört komplext och svårnavigerat område. Ofta kan detta arbete hamna i en slags modell av "damned if we do, damned if we don't". Som exempel kan aktiviteten med den aktiva pedagogen användas. Viss forskning pekar på att det finns en stor risk att pedagoger i den lärarledda aktiviteten reproducerar stereotypa könsroller och könsmönster, annan forskning visar att om barnen lämnas helt fria i leken så riskerar det i sin tur att stereotypa könsroller och könsmönster reproduceras. Detta pekar på att det inte finns några enkla svar på de utmaningar och 
möjligheter som omgärdar detta område. Ett första steg kan dock vara att peka ut, och problematisera kring, dessa utmaningar och möjligheter.

Denna studie pekar på att många av de utmaningar som går att finna när det kommer till förskolans arbete med genus och teknik går att hitta hos pedagogerna själva. En av utmaningarna består i vilken slags teknik som fokuseras i pedagogernas teknikdidaktiska samtal. Studien visar att det är teknik som av tradition kan kopplas samman med manlighet som får representera teknikstoffet i aktiviteterna, och då i synnerhet utifrån ett artefaktsperspektiv. Detta skapar åtminstone två olika slags utmaningar. Den ena handlar om att genom att belysa just dessa traditionellt sett manligt kodade artefakter för barnen så bidrar aktiviteterna till att reproducera vad som faktiskt räknas, och indirekt vad som inte räknas, som teknik. Den andra utmaningen handlar om att ett artefaktfokus, i detta fall ett fokus på skruvar, muttrar och gångjärn, gör att det blir svårare för pedagogerna att belysa teknikens mer holistiska sidor.

Det är intressant att valet av teknik som av tradition tillhört den manliga sfären inte görs oreflekterat hos deltagarna i studien. Det didaktiska samtal som skedde under mötesaktionerna hjälpte till att tydliggöra för deltagarna att de själva definierade teknik utifrån artefakter och manlighet. Samtalet fick dem dessutom att kritiskt granska vilka slags tekniska aktiviteter de historiskt sett genomfört under sina karriärer i förskolan. Trots detta valde gruppen ändå i slutändan att fokusera på manligt kodade artefakter i verksamhetsaktionerna. Även om deltagarna alltså verkade komma till någon slags insikt kring sin egen syn på, och definition av teknik, så fick detta ingen större effekt på hur de valde att visa fram teknik i förskolan. I det avseendet verkar alltså inte de didaktiska samtalen i studien varit tillräckliga för att en förändring av deltagarnas frames of references skulle äga rum (se Illeris, 2014a, 2014b). En förklaring till detta skulle kunna hänga samman med att det var flickors, i form av homogen grupp, tillgång till den traditionellt manligt kodade tekniken som fokuserades när gruppen diskuterade hur traditionella könsmönster och könsroller skulle kunna motverkas. Detta fokus fick stå relativt 
oproblematiserat under studiens genomförande. Här hade exempelvis ny litteratur kring detta problemområde kunnat lyftas in i gruppen. Tyvärr valde jag, efter verksamhetsaktion 1 , att inte ta in mer läsning av litteratur i gruppen. Detta val grundade sig på att deltagarna uttryckte att de vid tidpunkten hade en stressig tillvaro. Jag ville helt enkelt inte att deltagandet i studien skulle bli en börda, vilket kunde fă till följd att deltagare valde att kliva av. I backspegeln kunde exempelvis Faulkners (2001, 2003) definitioner av teknikens könskodning kunnat användas för att hjälpa gruppen att reflektera över vad som hände i studien, både i förhållande till deltagarnas egen tekniksyn och de aktiviteter som genomfördes.

Även om studien inte gav några större förändringar i vilken slags teknik som deltagarna valde att fokusera på i aktiviteterna, så kan gruppen ha varit på väg mot en förändring av sina antaganden om att artefakters genusprägling är ett effektivt sätt att identifiera stereotypa tankar hos barnen. Gruppen återkom vid flera tillfällen under studien till artefakters genusprägling och att det är just genom artefakternas attribut som det går att köna den tekniska aktiviteten, och därigenom synliggöra huruvida barnen har stereotypa tankar eller ej. Detta är i linje med vad Eidevald (2009) kunde konstatera i sin studie - att det i synnerhet är yttre attribut som kläder och leksaker som problematiseras av förskollärare i förhållande till genus. En förklaring till varför synliggörandet av barnens tankar fick en så pass framträdande roll i gruppens arbete kan hänga samman med den tydliga framskrivningen i den nuvarande läroplanen där det anges att det är förskolans uppdrag att motverka traditionella könsmönster och könsroller. Gruppen hade stora förväntningar på att användandet av könskodade artefakter skulle ge en hel del information om barnens eventuella stereotypa eller icke-stereotypa tankar om teknik. Resultatet av studien pekar dock på att dessa artefakter i väldigt liten utsträckning synliggjorde just sådana tankar hos barnen. Tyvärr var vi tvungna att avsluta studien innan vi hann följa upp verksamhetsaktion 3 på ett mer ingående sätt. Därför fick deltagarna aldrig någon större möjlighet att diskutera resultatet av verksamhetsaktion 3 och ställa barnens syn (eller ickesyn) på artefakters genuskodning i förhållande till sin egen. 
En didaktisk utmaning när det handlar om teknik och genus i förskolan verkar alltså handla om att inte låta artefakters attribut få en för omfattande roll i planerandet och genomförandet av aktiviteterna.

En annan utmaning som går att identifiera med hjälp av studien handlar om pedagogernas syn på barnens relation till teknik. Även om den här studien i sig inte hade utgångspunkten att det finns grundläggande skillnader mellan flickors och pojkars intresse för teknik, vilket många studier har haft, så kretsade ändå gruppens diskussioner delvis kring att det finns skillnader i hur pojkar och flickor tar sig an tekniska aktiviteter. Det går å ena sidan att argumentera för att gruppen endast följde vart observationerna ledde, att dessa helt enkelt visade att det var pojkarna som tog större kontroll över materialet och själva konstruktionsprocessen (se exempelvis MacNaughton, 1997). $\AA$ andra sidan verkade detta resonemang bygga på agerandet hos ett fåtal av pojkarna i verksamhetsaktionerna. Dessa pojkars agerande verkade stämma överens med hur deltagarna pratade om och beskrev "görarna". Precis som hos MacNaughton (1997) var det alltså i synnerhet de pojkar som benämndes som macho, och som stängde ute flickorna i aktiviteterna, som ibland fick representera hela gruppen pojkar. Aktionsforskningsgruppen verkade alltså utgå från att det är pojkar, som homogen grupp, som positionerar sig främst i de tekniska aktiviteterna, även om detta agerande inte stämde för alla pojkar. Risken med denna utgångspunkt är att den skulle kunna sätta agendan för hur alla pojkar bemöts och därmed vara en del i normaliseringsprocessen i synen på skillnader mellan pojkar och flickor (Eidevald, 2009), och därmed verka konserverande för de genusstrukturer gruppen hade som syfte att utmana (Johnston \& Dunne, 1996). Det går också att konstatera att även om denna studie inte hade som utgångspunkt att fokusera på det otraditionella valet, som exempelvis Berner (2003b) påpekar att många studier har gjort, så hamnar gruppen ändå i denna utgångspunkt. Även om det hos gruppen fanns ett fokus på att huvuduppgiften var att ge alla barn möjlighet att få syn på tekniken i vardagen och bli intresserade av teknik, så var det normer kring manlighet och teknik som satte agendan. Det verkade finnas en underliggande tanke om att de 
tekniska aktiviteterna, och de traditionellt sett manligt kodade artefakterna som lyftes fram i dessa, skulle berika flickorna och deras intresse för teknik mer än pojkarna, och på så sätt motverka traditionella stereotyper och genusstrukturer. Forskning som fokuserat det otraditionella valet har i grund och botten utgått från att det är flickorna och deras attityd till teknik som bör förändras i en "positiv" riktning, detta eftersom de inte anses ha vuxit upp med samma nära relation till tekniken som pojkarna (Berner, 2003b). Detta sätt att beskriva barnen framkom även i gruppens diskussioner där pojkarna beskrevs utifrån att de hade mer erfarenheter rörande teknik med sig från sina hem än flickorna.

Utifrån studien går det att se att så länge diskussionerna rör sig på en mer strukturell nivå, där inte specifika barn står i centrum, så beskrivs arbetet med teknik och genus mer i förhållande till läroplanens skrivelse om att motverka kulturellt formade karaktärsdrag. Men när diskussionerna rör sig ned på en individnivå verkar barnen istället beskrivas utifrån förutbestämda karaktärsdrag, vilka verkar hänga samman med stereotyper kring teknik. Resultatet i den här studien pekar alltså på att när läroplanens mål om att motverka stereotyper ska omsättas i praktiken, i synnerhet i relation till enskilda barn, kan det istället bli så att könsstereotypa karaktärsdrag bejakas och kanske till och med förstärks. Återigen hade en möjlighet för att utmana deltagarnas antaganden kunnat vara att lyfta in ny litteratur i studien. Exempelvis hade information om forskning gällande det otraditionella valet kunnat användas till att hjälpa gruppen att reflektera över sin syn på barnen och de tekniska aktiviteterna. Ett sådant raster för analys av verksamhetsaktionerna skulle ha kunnat ge deltagarna en djupare förståelse av sitt eget förhållningssätt till teknik i förskolan. En naturlig fortsättning på denna studie hade därför kunnat vara att undersöka om införandet av ny litteratur, i detta fall angående teknikens genusprägling och hur flickors förhållande till teknik problematiserats historiskt sett, hade kunnat hjälpa gruppen att ta sig förbi vissa didaktiska utmaningarna.

Vad det gäller möjligheter för utvecklandet av pedagogernas agerande och bemötande av barnen i tekniska aktiviteter går det att 
konstatera att studien visar på en möjlig väg framåt. Synliggörandet av pedagogens egen roll som ledare i aktiviteten verkar vara en viktig faktor för förändring. Det går att se att detta synliggörande förändrade hur deltagarna pratade om sin roll som ledare i en teknisk aktivitet i förskolan. I synliggörandet av ledarrollen spelade aktionsforskning som metod en tydlig roll. Deltagarna fick genom aktionsforskningsprocessen möjlighet att kritiskt granska och ifrågasätta sina egna förgivettagna antaganden om hur de vanligtvis agerar i mötet med barnen, vilket enligt Illeris (2014a; 2014b) är en förutsättning för att förändring ska kunna äga rum. Det ska tilläggas att jag inte kan uttala mig om huruvida en faktisk förändring verkligen tog plats hos deltagarna i gruppen, utan bara att det fanns tecken på att så var fallet. För att ta reda på om en förändring skedde i form av att deltagarna verkligen ändrade sitt sätt att planera och genomföra tekniska aktiviteter på sina respektive avdelningar, så hade det behövts göras en uppföljande studie i form av både observationer av deltagarnas agerande i sagda tekniska aktiviteter, samt genom djuplodande intervjuer med deltagarna. Däremot kan resultatet av studien ge en indikation på vilka faktorer som gav deltagarna förutsättningar att reflektera över sitt eget agerande i aktiviteterna, det vill säga faktorer som verkar underlätta för att en förändringsprocess ska ske. Utifrån detta perspektiv kan därför studiens resultat ses som intressanta och viktiga för pedagoger och grupper i liknande situationer, som har som mål att granska och utveckla sitt arbete med tekniska aktiviteter. 



\section{Referenser}

Altrichter, H., Posch, P. \& Somekh, B. (2000). Teachers Investigate their Work: An introduction to the methods of action research. London: Routledge.

Andersson, K., Hussenius, A., \& Gustafsson, C. (2009). Gender Theory as a Tool for Analyzing Science Teaching. Teaching and Teacher Education: An International Journal of Research and Studies, 25(2), 336-343.

Attride-Stirling, J. (2001). Thematic networks: an analytic tool for qualitative research. Qualitative research, 1(3), 385405 .

Axell, C. (2013). Teknikundervisningen i förskolan: En internationell utblick.

Bjurulf, V. (2011). Teknikdidaktik. Norstedts.

Björndahl, C.R.P. (2005). Det värderande ögat: Observation, utvärdering och utveckling $i$ undervisning och handledning. Stockholm: Liber.

Berner, B. (1999). Perpetuum mobile? : teknikens utmaningar och historiens gång. Lund : Arkiv.

Berner, B. (2003a). Vad har teknik med genus att göra? In B. Berner (Ed.), Vem tillhör tekniken?: Kunskap och kön $i$ teknikens värld (15-21). Lund: Arkiv förlag.

Berner, B. (2003b). Kön, teknik och naturvetenskap i skolan. In B. Berner (Ed.), Vem tillhör tekniken?: Kunskap och kön $i$ teknikens värld (119-144). Lund: Arkiv förlag.

Berner, B. (2003c). Kvinnor i ingenjörsarbete. In B. Berner (Ed.), Vem tillhör tekniken?: Kunskap och kön i teknikens värld (175-200). Lund: Arkiv förlag.

Berner, B. (2003d). Inte bara ingenjörer. Kvinnors arbete och utbildning i tjänstesamhället. In B. Berner (Ed.), Vem tillhör tekniken?: Kunskap och kön i teknikens värld (229254). Lund: Arkiv förlag.

Berner, B. (2003e). Kvinnor i teknikens värld. In B. Berner (Ed.), Vem tillhör tekniken?: Kunskap och kön i teknikens värld (115-117). Lund: Arkiv förlag.

Berner, B., \& Nyborg, M. (2004). Ifrågasättanden: forskning om genus, teknik och naturvetensakp. Linköping: Tema Teknik och social förändring. 
Braun, V., \& Clarke, V. (2006). Using thematic analysis in psychology. Qualitative research in psychology, 3(2), 77-101.

Browne, N., \& Ross, C. (1991). Girls' Stuff, Boys' Stuff: Young Children Talking and Playing. In N. Browne (Ed.), Science and technology in the early years: an equal oppurtunities approach (37-51). Milton Keynes: Open U.P.

Chalmers (2017). Vera Sandberg - Sveriges första kvinnliga ingenjör. Hämtad från https://www.chalmers.se/sv/forskning/filmer/Sidor/Vera -Sandberg-Sveriges-forsta-kvinnliga-ingenjor.aspx

Connell, R. (2009). Om genus (2:a utvidgade och omarbetade upplagan.). Göteborg: Daidalos.

Crisp, T., \& Hiller, B. (2011). 'Is This a Boy or a Girl?': Rethinking Sex-Role Representation in Caldecott Medal-Winning Picturebooks, 1938-2011. Children's Literature in Education, 42(3), 196-212. doi: 10.1007/s10583-0119128-1

Dirkx, J.M., \& Mezirow, J. (2014). Musings and Reflections on the Meaning, Context and Process of Transformaive Learning: A Dialouge Between John M. Dirkx and Jack Mezirow. Journal of Transformative Education, 5(4), 535-559.

Edström, C. (2006). Pedagogues' Constructions of Gender Equality in Slected Swedish Preschools: A qualitative study. Education Inquiry, 4(2), 123-139.

Eidevald, C. (2009). Det finns inga tjejbestämmare: Att förstå kön som position i förskolans vardagrutiner och lek. Jönköping University .

Faulkner, W. (2001, February). The technology question in feminism: A view from feminist technology studies. In Women's studies international forum (Vol. 24, No. 1, pp. 79-95). Pergamon.

Faulkner, W. (2003). Teknikfrågan i feminismen. In B. Berner (Ed.), Vem tillhör tekniken?: Kunskap och kön i teknikens värld (23-52). Lund: Arkiv förlag.

Fleer, M. (2000). Working Technologically: Investigations into How Young Children Design and Make During Technology Education. International Journal of Technology and Design Education, 10, 43-59. 
Folkesson, L. (2012). Forskning - på vems villkor? In K. Rönnerman (Ed.), Aktionsforskning i praktiken: förskola och skola på vetenskaplig grund (41-54). Lund: Studentlitteratur.

Hallström, J., Elvstrand, H. \& Hellberg, K. (2014). Gender and technology in free play in Swedish early childhood education. International Journal of Technology \& Design Education, 25(2), 137-149.

Hedlin, M. (2009). Konstruktionen av kön i skolpolitiska texter 1948-1994, med särskilt fokus på naturvetenskap och teknik. Umeå: Umeå Universitet.

Herr, K., \& Anderson, G. L. (1999). The new paradigm wars: Is there room for rigorous practitioner knowledge in schools and universities?. Educational researcher, 28(5), 12-40.

Herr, K., \& Anderson, G. L. (2005). The Action Research Dissertation: A Guide for Students and Faculty. Thousand Oaks: Sage Publications Ltd.

Hultén, M. (2013) Teknik för alla - Efterkrigstidens skolreformer och det nya skolämnet Teknik. Hallström, J., Hultén, M \& Lövheim, D (red.). Teknik som kunskapsinnehåll i svensk skola 1842-2010 (169-214). Gidlunds förlag.

Hundeide, K., \& Järvå, H. (2006). Sociokulturella ramar för barns utveckling: barns livsvärldar. Studentlitteratur.

Illeris, K. (2014a). Transformative Learning re-defined: as changes in elements of the identity. International Journal of Lifelong Education, 33(5), 573-586.

Illeris, K. (2014b). Transformative Learning and Identity. Journal of Transformative Education, 12(2), 148-163.

Jarvis, T., \& Rennie, L. J. (1998). Factors that Influence Children's Developing Perceptions of Technology. International Journal of Technology \& Design Education, 8(3), 261-279.

Johnston, J., \& Dunne, M. (1996). Revealing assumptions: problematising research on gender and mathemathics and science education. In L. H. Parker, L. J. Rennie \& B. J. Fraser (Eds.), Gender, science and mathemathics: shortening the shadow (53-63). Dordrecht: Kluwer academic press. 
Kimmel, M. S. (2000). The gendered society. Oxford university press:New York

KTH. (2009). Brita Snellman - den första ordinarie kvinnliga studenten vid KTH. Hämtad från https://archive.is/20120525073932/http://intra.kth.se/a dministration/dokument/Arkivering/arkivutstalln/kvinnliga

Larsson, Staffan. (2005). Om kvalitet i kvalitativa studier. Retrieved May, 15, 2014, from http://proxy.lnu.se/login?url=http://search.ebscohost.co $\mathrm{m} /$ login.aspx?direct $=$ true $\& \mathrm{db}=$ edsswe $\& \mathrm{AN}=$ edsswe.oai.Di VA.org.liu. $24757 \&$ site $=$ eds-live\&scope $=$ site

Lincoln, Y. S. \& Guba, E.G. (1985). Naturalistic inquiry. Beverly Hills: Sage.

Locke, T., Alcorn, N., \& O’Neill, J. (2013). Ethical issues in collaborative action reseach. Educational Action Research, 21(1), 107-123.

Lyon, E. (1991). The Role of the Nursery School in Developing a Non-Sexist Approach to Science and Technology. In N. Browne (Ed.), Science and technology in the early years: an equal oppurtunities approach (67-76). Milton Keynes: Open U.P.

Lövheim, D. (2013) Teknikens gränser - Formering och positionering av grundskolans teknikämne 1975-2010. Hallström, J., Hultén, M \& Lövheim, D (red.). Teknik som kunskapsinnehåll $i$ svensk skola 1842-2010 (214-250). Gidlunds förlag.

Oldenziel, R. (1999). Making Technology Masculine: Men, Women and Modern Machines in America, 1870-1945. Amsterdam: Amsterdam University Press.

MacNaughton, G. (1997). Who's got the power? Rethinking gender equity strategies in early childhood. International Journal of Early Years Education, 5(1), 57-66.

Mawson, B. (2010). Children's developing understanding of technology. International Journal of Technology \& Design Education, 2O(1), 1-13.

Mawson, B. (2013). Emergent technological literacy: what do children bring to school? International Journal of Technology \& Design Education, 23(2), 443-453. 
Mellström, U. (1999). Män och deras maskiner. Nora: Nya Doxa. Mellström, U. (2003). Teknik och maskulinitet. In B. Berner (Ed.), Vem tillhör tekniken?: Kunskap och kön i teknikens värld (57-76). Lund: Arkiv förlag.

Mezirow, J. (1997). Transformative Learning: Theory to Practice. New Directions for Adult and Continuing Education, 1997(74), 5-12.

Mezirow, J. (2003). Transformative Learning as Discourse. Journal of Transformative Education, 1(1), 58-63.

Månsson, A. (2000). Möten som formar: Interaktionsmönster på förskolan mellan pedagoger och de yngsta barnen i ett genusperspektiv. Studia psychologica et paedagogica: Series altera.

Nissen, J. (2003). Datorkulturen - en manlig historia. In B. Berner (Ed.), Vem tillhör tekniken?: Kunskap och kön $i$ teknikens värld (77-92). Lund: Arkiv förlag.

Norris, S., Geenen, J., Metten, T. \& Pirini, J. (2014). Collecting video data: Role of the researcher. In S. Norris \& C.D. Maier (Ed.), Interactions, images and texts: a reader in multimodality (213-232). Boston/Berlin: Walter de Gruyter, Inc.

Nyberg, A. C. (2003). Kvinnor som uppfinnare och innovatörer. In B. Berner (Ed.), Vem tillhör tekniken?: Kunskap och kön i teknikens värld (201-228). Lund: Arkiv förlag.

Nylund, M., Sandback, C., Wilhelmsson, B., \& Rönnerman, K. (2010). Aktionsforskning i förskolan: trots att schemat är fullt. Stockholm: Lärarförbundets Förlag.

Oskamp, S., Kaufman, K. \& Wolterbeek, L. Atchison. (1996). Gender role portrayals in preschool picture books. Journal of Social Behavior and Personality, 11(5), 27-39.

Persson, S. (2008). Forsningscirklar: en vägledning. Retrieved Septamber 8, 2014, from http://dspace.mah.se/dspace/bitstream/handle/2043/715 5/forskningscirklar\%20\%20en\%20v\%E4gledning.pdf;jsessionid=1A06C2018EEB 5D06301699CoEBBA8C82? sequence $=1$

Pirini, J., Norris, S., Geenen, J. \& Matelau, T. (2014). Studying social actors: Some thoughts on ethics. In S. Norris \& C.D. Maier (Ed.), Interactions, images and texts: a reader in 
multimodality (233-242). Boston/Berlin: Walter de Gruyter, Inc.

Robson, C. (2011). Real world research : a resource for users of social research methods in applied settings. Chichester: Wiley.

Rönnerman, K. (1998). Vad är aktionsforskning? In K. Rönnerman (Ed.), Aktionsforskning i praktiken: förskola och skola på vetenskaplig grund (21-40). Lund: Studentlitteratur.

Rönnerman, K. (2010). Aktionsforskning - en väg mot kvalitet och förbättring. Aktionsforskning i förskolan: trots att schemat är fullt. Stockholm: Lärarförbundets Förlag.

Rönnerman, K. (2012a). Vad är aktionsforskning? In K. Rönnerman (Ed.), Aktionsforskning i praktiken: förskola och skola på vetenskaplig grund (21-40). Lund: Studentlitteratur.

Rönnerman, K. (2012b). Systematiskt kvalitetsarbete i förskolan. In K. Rönnerman (Ed.), Aktionsforskning i praktiken: förskola och skola på vetenskaplig grund (89-104). Lund: Studentlitteratur.

Salminen-Karlsson, M. (2003). Hur skapas den nya teknikens skapare?. In B. Berner (Ed.), Vem tillhör tekniken?: Kunskap och kön i teknikens värld (145-174). Lund: Arkiv förlag.

SCB. (2014). På tal om kvinnor och män: Lathund om jämställdhet 2014. Örebro: Statistiska centralbyrån, enheten för befolkningsstatistik. Hämtad från http://www.scb.se/Statistik/_Publikationer/LE0201_201 3B14_BR_X10BR1401.pdf

Siu, K., \& Lam, M. (2005). Early Childhood Technology Education: A Sociocultural Perspective. Early Childhood Education Journal, 32(6), 353-358.

Skolverket. (1998). Läroplan för förskolan Lpfö 98. Stockholm: Skolverket .

Skolverket. (2000). Med demokrati som uppdrag: En temabild om värdegrunden. Stockholm: Skolverket.

Skolverket. (2010). Läroplan för förskolan Lpfö 98: Reviderad 2010. Stockholm: Skolverket . 
Skolverket. (2016). Läroplan för förskolan Lpfö 98: Reviderad 2016. Stockholm: Skolverket .

Somekh, B. (2006). A methodology for change and development. Maidenhead: Open University Press.

SOU 2004:115. Den könade förskolan: Om betydelsen av jämställdhet och genus $i$ förskolans pedagogiska arbete. Hämtad från http://www.regeringen.se/49b71d/contentassets/72e823f e19c845e2acbebfdd5bbfee21/den-konade-forskolan---ombetydelsen-av-jamstalldhet-och-genus-i-forskolanspedagogiska-arbete

SOU 2005:66. Makt att forma samhället och sitt eget liv: jämställdhetspolitiken mot nya mål. Hämtad från http://www.regeringen.se/sb/d/108/a/47912

SOU 2006:75. Jämställd förskola: Om betydelsen av jämställdhet och genus i förskolans pedagogiska arbete. Hämtad från http://www.regeringen.se/rattsdokument/statensoffentliga-utredningar/2006/07/sou-200675/

Stables, K. (1997). Critical issues to consider when introducing technology education into the curriculum of young learners. Journal of technology education, 8(2), 50-65.

Statistiska centralbyrån. (2016). På Tal Om Kvinnor Och Män : Lathund Om Jämställdhet. Hämtad från https://www.scb.se/Statistik/_Publikationer/LE0201_20 15B16_BR_X10BR1601.pdf

Sundin, B. (2006). Den kupade handen: Människan och tekniken. Stockholm: Carlsson Bokförlag.

Sundqvist, P., Nilsson, T., \& Gustafsson, P. (2015). Svensk förskolepersonals beskrivningar av teknik. LUMAT: Luonnontieteiden, matematiikan ja teknologian opetuksen tutkimus ja käytäntö, 3(2), 237-257.

Sundqvist, P., \& Nilsson, T. (2016). Technology education in preschool: providing oppurtunities for children to use artifacts and to create. International Journal of Technology and Design Education, 28, 29-51.

Säljö, R. (2008). Lärande i männsikans landskap. In H. Rystedt \& R. Säljö (Ed.), Kunskap och människans redskap: teknik och lärande (13-27). Studentlitteratur. 
Tallberg Broman, I. (2009) Mamma, pappa, förskolebarn: Om förskolan som jämställdhetsprojekt. Wernersson, I (red.). Genus i förskola och skola: Förändringar i policy, perspektiv och praktik (61-83). Göteborgs Universitet.

Thonberg, R. (2004). Värdepedagogik. Pedagoisk Forskning $i$ Sverige, 9(2), 99-114.

Trepanier-Street, M. L., \& Romatowski, J. A. (1999). The Influence of Children's Literature on Gender Role Perceptions: A Reexamination. Early Childhood Education Journal, 26(3), 155-159.

Turja, L., Endepohls-Ulpe, M., \& Chatoney, M. (2009). A conceptual framework for developing the curriculum and delivery of technology education in early childhood. International Journal of Technology \& Design Education, 19(4), 353-365.

Vetenskapsrådet. (UA). Forskningsetiska principer inom humanistisk-samhällsvetenskaplig forskning. Vetenskapsrådet. Hämtad från http://www.codex.vr.se/texts/HSFR.pdf

Wajcman, J. (1991). Feminism Confronts Technology. Cambridge: Polity Press.

Weiner, G. (2005). Educational Action Research: theory, practice and action. Stockholm: Vetenskapsrådet.

Wernersson, I. (2009) Pedagogerna och jämställdheten. Wernersson, I (red.). Genus i förskola och skola: Förändringar $i$ policy, perspektiv och praktik (23-42). Göteborgs Universitet.

Westlander, G. (2006). Researcher Roles in Action Research. In K. A. Nielsen \& L. Svensson (Eds.), Action and Interactive Research: Beyond practice and theory (45-61). Maastricht: Shaker Publishing.

Zeni, J. (2001). A guide to ethical decision making for insider research. In J. Zeni (Ed.), Ethical issues in practitioner research (153-173). New York: Teachers College Press.

Ärlemalm Hagsér, E., \& Pramling Samuelsson, I. P. (2011). Många olika genusmönster existerar samtidigt i förskolan. Pedagogiskforskning i Sverige, 14(2), 89-109. 


\section{Bilagor}

\section{Bilaga 1 - Brev till vårdnadshavare}

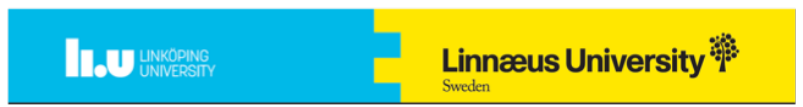

Information till vårdnadshavare för barn på

och

$\mathrm{Hej}$ !

Jag heter Johan Boström och läser en forskarutbildning i teknikens didaktik på Linnéuniversitetet/Linköpings Universitet. Jag har precis startat upp ett aktionsforskningsprojekt tillsammans med åtta lärare på —och Under hösten -15 och våren -16 kommer vi att skapa utrymme och möjlighet för ett antal övningar som berör teknik i den dagliga verksamheten. Kortfattat är syftet med dessa att öka kunskapen kring hur teknik i vardagen kan synliggöras för barnen samt hur ett klimat där alla kan känna samhörighet med teknik kan skapas. Övningarna kommer att observeras och videofilmas. De enda som kommer att ha tillgång till dessa filmer är jag själv, lärarna i gruppen, samt mina handledare på Linköpings universitet - Magnus Hultén och Per Gyberg.

Förskolechef

och biträdande förskolechef

(ill undersökningen. Förutom detta behöver jag även er tillåtelse som vårdnadshavare till att ert barn medverkar i undersökningen.

Om det är något ni undrar över kan ni nå mig på johan.bostrom@Inu.se

Med vänliga hälsningar

Johan Boström

Jag samtycker till att mitt barn deltar i undersökningen.

Jag samtycker inte till att mitt barn deltar i undersökningen.

Barnets namn:

Vårdnadshavares namnteckningar: 


\section{Bilaga 2 - Sammanfattning av mötesaktioner, verksamhetsaktioner och informationsmöten}

I denna bilaga kommer de tretton mötesaktionerna, de tre verksamhetsaktionerna och informationsmötet för vårdnadshavare att sammanfattas i kronologisk ordning. Sammanfattningarna belyser i breda drag vad som skedde under respektive aktion och möte, och hur detta informerade vad som kom att bli nästa steg i forskningsprocessen.

I mars 2015 träffade jag aktionsforskningsgruppen för första gången under en kortare introduktionsträff (för en beskrivning av hur gruppen bildades, se kapitel 4.7.2). På grund av sjukdom kunde endast fem av deltagarna vara på plats, tre från Katod och två från Anod. Under introduktionsträffen gav jag återigen en kortfattad beskrivning av syftet med studien samt en beskrivning av aktionsforskning som metod. Jag bad deltagarna att inför gruppens första regelrätta möte läsa tre kapitel ur Aktionsforskning i praktiken - förskola och skola på vetenskaplig grund (K. Rönnerman (Ed.), 2012) samt några delar ur Aktionsforskning $i$ förskolan - trots att schemat är fullt (Nylund et al., 2010). Detta gjordes för att deltagarna skulle få en möjlighet att sätta sig lite djupare in i hur aktionsforskning går till, så att vi under vårt första möte kunde "hit the ground running". Deltagarna fick också i uppgift att inför det första mötet anteckna tre minnen gällande teknik. Ett positivt teknikminne, ett negativt teknikminne och ett genus-och-teknikminne (jag påpekade att även detta minne kunde vara av en positiv eller negativ natur). Syftet med denna uppgift var att använda deltagarnas teknikminnen som utgångspunkt i gruppens gemensamma diskussion av teknik som företeelse och kunskapsfält.

Det planerades in tretton träffar under det dryga år som gruppen fick till sitt förfogande, från maj 2015 till juni 2016. De två första mötena hölls i maj respektive juni 2015. Efter detta träffades gruppen en gång i månaden mellan september 2015 och juni 2016. 


\section{Mötesaktion 1}

Det första mötet hölls den 27/5 - 2015 och fokuserade på deltagarnas egen syn på teknik. Tanken var att synliggöra deltagarnas (olika?) definitioner av begreppet teknik. Mötet startade med att jag lade upp följande artefakter på bordet framför deltagarna:

Transformer (humanoid robot/bil)
T-shirt
Konservburk
Locktång
Smartphone
Pingisracket
Gaffel
Legobil

Skiftnyckel

Resespel (Fia)

Bok

Hörlurar

Strumphängare(strumpbläckfisk)

Kaffekopp

Batteri

Deltagarna ombads sedan, tyst för sig själva, välja ut de två artefakter som bäst representerade deras egen definition av teknik. Efter detta presenterade deltagarna sina val för varandra och förklarade varför de valt just dessa artefakter. I samband med detta diskuterades också vilka teknikminnen som deltagarna plockat med sig. Denna del av mötet avslutades sedan med att jag bytte ut artefakterna på bordet mot ett antal bilder föreställande olika mänskliga aktiviteter - arbetare på ett löpande band i en bilfabrik, barn som cyklar, barn som bygger med klossar, barn som leker i en sandlåda, gatumusikanter, någon som stryker, en person som pratar i telefon, arbetare vid symaskiner i en textilfabrik, händer på en tv-spelskontroll, en person som programmerar samt en person som läser en bok. Deltagarna ombads sedan återigen att plocka ut de två bilder som de tyckte bäst representerade deras egen definition av teknik. Deltagarna presenterade sedan sina val för varandra och förklarade varför de valt just dessa aktiviteter. Detta följdes av en allmän diskussion om vad som räknas som teknik och varför.

Inför nästkommande mötesaktion, den 17/6, fick deltagarna ett antal uppgifter. Dels skulle de fundera kring huruvida de ser några uppenbara problem i verksamheten som går att relatera till teknik och genus. De fick också i uppgift att fundera på om diskussionerna under detta möte väckt några nya teknikminnen (positiva, negativa, teknik-och-genus) till liv. Jag bad dem även 
att fundera på sin egen motivation till varför de ville vara en del av aktionsforskningsprojektet.

Till sist kom vi även fram till att införa "veckans teknik-ochgenusobservation". Tanken var att deltagarna, en gång i veckan, skulle anteckna (kortfattat) en observation gällande teknik och genus (alternativt enbart teknik) på respektive avdelning. Observationen skulle utgå från frågorna vad, var, när och vilka. Vad hände (kort beskrivning av situationen)? Var hände det (inne, ute, i något speciellt rum, på utflykten osv.)? När hände det (fri lek, lärarstyrd aktivitet, måltid osv.)? Vilka var med (antal barn, ålder, kön osv.)? Även om detta var något som deltagarna tyckte var en bra idé var det tyvärr inget som fick fäste. Förutom en handfull observationer i samband med våra första två mötesaktioner fick jag inte in några observationer. Detta hängde mycket samman med att deltagarna kände att det blev ytterligare en uppgift som skulle hinnas med. På grund av att jag inte ville att de skulle känna att deltagandet i studien blev en börda, och därigenom kanske tappa intresse att vara med, valde jag att hålla uppgifter utanför mötesaktionerna och verksamhetsaktionerna till ett minimum.

\section{Mötesaktion 2}

Den andra mötesaktionen skedde tre veckor efter den första, precis innan deltagarna skulle gå på semester. Mötesaktionen började med att deltagarna fick reflektera fritt över hur de tyckte att föregående mötesaktion hade varit. De kom då snabbt in på studiens utvecklingsområde. Diskussionerna handlade mycket om vilka aktiviteter inom teknik (både inomhus och utomhus) som barnen på förskolan erbjuds och vilka förutsättningar pedagogen ger barnen i dessa aktiviteter. För att ge alla i gruppen ett lite större spelrum i att uttrycka sina åsikter i frågan om hur de såg på sin egen roll och sin egen avdelning i förhållande till dessa frågor delade jag gruppen i två, vilka placerades i varsitt rum. De två grupperna fick sedan, under cirka 20 minuter, diskutera detta utvecklingsområde och hur de tänkte sig att en första verksamhetsaktion skulle kunna utformas. 
Grupperna samlades sedan igen och redogjorde för varandra vad de hade kommit fram till. Den ena gruppens diskussioner hade kretsat kring att utforma en slags teknikhörna, och hur det skulle gå att göra systematiska observationer i denna hörna. Gruppen hade också diskuterat vilka faktorer som kan påverka hur ett barn tar till sig ett visst material. Även den andra gruppen hade diskuterat den fysiska miljön (exempelvis en teknikhörna) men hade lagt betydligt större fokus på att problematisera ledarskapet hos pedagogen. Exempelvis lyftes skillnader på en lärarstyrd aktivitet och en aktivitet där förskollärarna agerar medupptäckare. Ett förslag som lades fram vara att försöka observera hur deltagarna själva förhåller sig till dessa två olika roller. Gemensamt för de båda grupperna var dock att de på något sätt ville jobba med att synliggöra och skapa intresse för teknik, både för barnen och för dem själva. I diskussionen lyftes att den kommande aktionen skulle kunna handla om att konstruera eller foga samman med hjälp av olika material, och att detta skulle kunna ske i en teknikhörna.

Tyvärr hann vi inte med att ta upp fler teknikminnen under denna mötesaktion. Den lilla mängd tid som fanns kvar efter ovanstående diskussion ägnades åt att ge deltagarna utrymme att förklara varför de ville vara en del av projektet. Deltagarna uttryckte i sina motiveringar en gemensam vilja av att utveckla sig själva och sin profession.

Innan vi avslutade delade jag ut fyra texthäften som jag hade plockat fram utifrån min analys av mötesaktion 1. Ett häfte fokuserade frågeställningen "vad är teknik?”, ett häfte handlade om definition av genus och det tredje belyste kopplingen mellan genus och teknik. Den sista texten handlade om hur skolämnet teknik förändrats från Lgr62 och fram till idag. Det var alltså en liten större textmassa som delades ut, men eftersom nästa möte inte var planerat förrän efter semestern, den 26 augusti, hoppades jag på att deltagarna inte skulle bli alltför stressade av läsningen.

\section{Mötesaktion 3}

Första delen av mötesaktion 3 gick åt till att diskutera den litteratur som delades ut i slutet av föregående möte och vad deltagarna 
plockat med sig utifrån läsningen. Deltagarna kom under mötet fram till att utvecklingsområdet fortfarande handlade om att synliggöra teknik i vardagen för barnen, att skapa ett intresse för teknik samt att se hur de själva förhåller sig i sin ledarroll. Efter lite diskussion så landade det i att detta skulle göras med hjälp av en teknikhörna. Vad som ska skulle ske i hörnan blev dock inte helt klargjort, inte mer än att det skulle handla om något slags konstruerande verksamhet. Fokus på diskussionen handlade istället om vilket material som skulle finnas i hörnan, hur detta material skulle införskaffas samt säkerhetsfrågor kopplade till materialet. Det hela utmynnade i att det material som skulle erbjudas barnen i hörnan var skruvar, muttrar och gångjärn.

Under detta möte fortsatte också diskussionerna som handlade om pedagogernas ledarskap. Deltagarna tänkte sig fortfarande att ett sätt att synliggöra detta skulle kunna vara att ha en verksamhetsaktion som var mer lärarledd eller lärarstyrd och en aktion som var mer öppen. Där den första utgick mer från att konstruera något utifrån ett uppdrag och den andra mer handlade om att barnen, på sina egna premisser, skulle få undersöka och testa materialet.

Under mötesaktionen beslutades det även att vi skulle hålla ett informationsmöte för vårdnadshavarna till barnen på förskolorna, detta för att ge alla som var intresserade av projektet en chans att få svar på sina (eventuella) frågor och en chans att göra sin röst hörd. Det bestämdes också att jag skulle sätta ihop en medgivandeblankett som deltagarna kunde dela ut till vårdnadshavare för påskrift (se bilaga 1).

\section{Mötesaktion 4}

Denna mötesaktion skedde den 30 september och öppnades med att vi tillsammans inventerade vilket material som pedagogerna hade samlat in. Större delen av tiden användes för att planera och strukturera den första verksamhetsaktionen. Gruppen diskuterade vad för slags lärarledd aktivitet som skulle utföras i teknikhörnan och kom snabbt in på att det valda materialet pekade i riktning mot att konstruera och foga samman. Det föreslogs att ett sätt att arbeta med detta kunde vara att ge barnen uppdraget 
att skapa en konstruktion som var så hållbar som möjligt. Gruppen föreslog även att det kunde vara intressant att koppla aktiviteten till det tema som de för tillfället jobbade med på de olika avdelningarna - böckerna om grodan och hans vänner.

Koncensus av denna diskussion blev att barnen som skulle ingå i den första verksamhetsaktionen skulle få uppdraget att konstruera ett stabilt hus med hjälp av en rad olika kartonger, vilka skulle kunna sammanfogas med hjälp av skruvarna, muttrarna och gångjärnen. Det bestämdes att uppdraget skulle utgå från ett problem där Grodan och hans vänner vill bygga ett hus som de skulle kunna bo i tillsammans. För att introducera detta arbete på de olika avdelningarna föreslogs att pedagogerna kunde börja med att, tillsammans med barnen, titta på olika slags hus och hur de är konstruerade. Detta skulle exempelvis kunna göras genom en teknikpromenad, med hjälp av bilder från nätet, eller böcker från biblioteket. Vi bestämde att varje avdelnings första verksamhetsaktion skulle bestå av fyra barn och att en eller två pedagoger skulle ansvara för genomförandet. Det visade sig också att pedagogerna hade lite olika tankar om var på respektive avdelning de ville placera teknikhörnan. I slutändan såg det ut på följande sätt:

Eva och Lena

Susanne

Anna och Malin

Jenny och Sara

Carina
4 flickor Stora rummet

$$
4 \text { pojkar Byggen }
$$

$$
2 f+2 p \quad \text { Ateljén }
$$

$2 p+2 f \quad$ Ateljén

$$
2 p+2 f \quad \text { Stora rummet }
$$

Datum för genomförandet av verksamhetsaktion 1 sattes till någon gång under vecka 43. Vi kom fram till att det vore bra om jag kunde dyka upp på de olika avdelningarna en stund innan filmningen och presentera mig själv för barnen.

Mötesaktionen avslutades med att vi kom överens om att även medupptäckaraktiviteten skulle genomföras som en kommande 
verksamhetsaktion. Precis som konstruktionsuppdraget skulle denna aktivitet genomföras tillsammans med fyra barn. Denna medupptäckaraktivitet skedde dock aldrig, vilket förklaras i sammanfattningen av möte 5 .

\section{Informationsmöte vårdnadshavare}

Tanken var först att vi skulle ha ett informationsmöte på rwspektive förskola, men då det visade sig att endast fem vårdnadshavare/vårdnadshavarpar visade intresse beslutade vi oss för att endast hålla ett gemensamt möte på Anod. Datum och tid för detta möte sattes till 18.0o på en vardag, detta för att ge möjlighet för så många som möjligt att medverka. Carina erbjöd sig att medverka som representant från förskolan. På själva mötet dök sedan endast två vårdnadshavare upp, båda hade varsitt barn placerat på Anod. Under mötet informerade jag bland annat om aktionsforskning som metod och vad som var fokus för studien.

\section{Verksamhetsaktion 1}

Verksamhetsaktion 1 genomfördes som planerat under vecka 43 och sammanlagt videofilmades 5 aktiviteter, vilket resulterade i cirka 8 timmar inspelat material. Efter detta spenderade jag cirka en vecka med att titta på filmerna och göra en första analys av olika trådar som jag ansåg var viktiga att lyfta i gruppen.

\section{Mötesaktion 5}

Inför möte 5 hade jag klippt ihop några korta filmsekvenser från verksamhetsaktion 1 (4-8 minuter vardera) för att illustrera de olika trådar jag identifierat.

Den första tråden handlade om ledarskapet, eller rättare sagt att deltagarna hade olika förutsättningar vid genomförandet av den första verksamhetsaktionen. Det visade sig att de pedagoger som var ensamma med fyra barn hamnade i en situation som för dem verkade mycket svår att överblicka. De hade uppenbara problem att ge alla barnen uppmärksamhet, både i form av handhavandeassistans vid konstruktionsarbetet och att utmana dem i deras problemlösningsarbete. Det var också uppenbart att det i dessa grupper skedde betydligt mindre samarbete mellan barnen för att 
lösa problemet än vad som skedde i de grupper där det fanns två pedagoger.

I nästa film hade jag försökt följa problemformuleringen som handlade om att synliggöra tekniken för barnen. I det här fallet fokuserade jag på i vilken utsträckning deltagarna lyfte fram gångjärnens funktion, samt skruvarnas och muttrarnas förmåga att sammanfoga material. Det som gick att se var att många av barnen hellre använde annat material till att foga samman de olika delarna, som exempelvis tejp, och att de i synnerhet hade svårt att upptäcka gångjärnens "avsedda" funktion. Det visade sig också att mycket av tiden gick åt till att försöka hitta muttrar, skruvar och gångjärn som var kompatibla med varandra.

Det tredje filmklippet vi tittade på handlade om vilka personer som barnen relaterade till när de använde sig av skruvarna, muttrarna och gångjärnen. Det gick att konstatera att de ofta pratade om en manlig person.

Nästa klipp vi tittade på handlade om vilka barn som fick mest uppmärksamhet under aktiviteterna. Vi började med att titta på Susannes aktivitet, där de fyra pojkarna visserligen fick i uppgift att konstruera huset tillsammans men gick sedan ändå åt varsitt håll och började bygga var för sig. Det gick att konstatera att det var de två barn som lät och syntes mest som fick större delen av Susannes uppmärksamhet. Efter detta tittade vi på ett filmklipp från Saras och Jennys aktion (två flickor och två pojkar). Även här gick det att se att deltagarna gav mest uppmärksamhet till de barn som tog störst utrymme.

De sista två filmklippen handlade om olika fokus hos barnen när det gällde aktiviteten. För de flesta av barnen verkade den sociala kontexten spela en viktig roll där konstruerandet för Grodan och hans vänner, samt möjlighet till lek var i fokus. För några av barnen, i synnerhet de ovan nämnda barnen hos Susanne, verkade det som att konstruerandet i sig var det som spelade viktigast roll. 
Vi avslutade mötesaktionen med att försöka binda ihop vad vi sett utifrån den första verksamhetsaktionen och vad som behövde förändras inför nästa. För det första så beslutades det att de pedagoger som varit ensamma under den första verksamhetsaktion endast skulle ha två barn i nästa. Ytterligare ett förslag som lyftes var att skapa struktur genom en fast fysisk plats under aktiviteten, detta skulle exempelvis kunna göras genom att allt arbete koncentrerades till ett bord. Vi diskuterade också att materialet behövde förberedas på ett bättre sätt. Dels bestämde vi att dra ned på mängden material som användes och dessutom försöka göra det mer hanterbart för barnen så att inte all tid under nästkommande verksamhetsaktion behövde användas för att hitta kompatibelt material. Vi bestämde också att själva uppdraget skulle kunna förändras för att mer belysa funktionen hos skruvarna, muttrarna och gångjärnen. Jag föreslog att ett sätt att närma sig funktionen hos materialet skulle kunna vara att barnen fick i uppdrag att konstruera dörrar och fönster till ett färdigt "hus”. På detta sätt skulle dessutom kontexten av uppdraget finnas kvar.

\section{Mötesaktion 6}

Denna mötesaktion skedde fyra veckor efter den förra. Inför detta möte hade jag skickat ut ett utdrag av transkriptionerna från mötesaktion 5 till deltagarna. Detta utdrag belyste de diskussioner som förts i gruppen utifrån de olika filmklippen. Bland annat hade vi konstaterat att även om barnen använde skruvar och muttrar för att sammanfoga kartongerna så var det få av dem som använde detta material i kombination med gångjärnen. Gångjärnens funktion att öppna och stänga var inget som blev direkt synligt för barnen i verksamhetsaktionen 1. Exempelvis spelade gångjärnets form en tydligare roll då det limmades fast för att representera formen av ett fönster. Vi återkom även under mötet till idén om ett hus utan dörrar, som jag presenterade under förra mötet, och om detta skulle kunna vara ett sätt att jobba med funktionen hos gångjärnen. Uppdraget skulle i sådana fall vara att låta barnen, på olika sätt, tillverka dörrar till huset. De skulle då kunna använda olika material för att konstruera dörrar som skulle uppfylla funktionen öppna/stänga. Detta skulle dels kunna hjälpa dem att fylla på sin "problemlösningsryggsäck", 
samtidigt som det kunde hjälpa dem att börja reflektera över olika materials funktionsduglighet för ett specifikt problem.

Under detta möte kasserades även idén om att nästa verksamhetsaktion skulle vara av mer utforskande karaktär där barnen inte får ett uppdrag utan mer får ta sig an materialet på egen hand. Deltagarna utryckte en oro om att detta sätt att arbeta inte skulle hjälpa barnen att få samma förutsättningar i själva aktiviteten. Dessutom skulle ett sådant upplägg kunna riskera att inte belysa ledarrollen särskilt väl, vilket var en del av gruppens identifierade utvecklingsområde. Även verksamhetsaktion 2 kom därför att fokusera på det lärarstyrda uppdraget. Gruppen återkom även till utgångspunkten att ett sätt att skapa tydligare struktur i aktiviteten skulle kunna vara att avgränsa den yta som barnen befinner sig på när de utför uppdraget. Det beslutades därför att det i nästa verksamhetsaktion skulle finnas ett bord för själva konstruktionsarbetet och ett bord för materialförvaringen. Vi diskuterade även hur den kommande verksamhetsaktionen skulle kunna utformas för att hjälpa oss att få en större förståelse för om barnen hade könsstereotypa uppfattningar eller ej gällande teknik.

Sammanfattningsvis kom gruppen fram till följande upplägg för verksamhetsaktion 2. Barnen ska få en tom mjölkkartong (10 l versionen) som redan är förberedd utifrån en rad olika faktorer. Paketet ska föreställa ett rum/hus som för tillfället saknar dörrar och fönster. Barnens uppgift kommer att bli att hitta olika sätt att tillverka dörrar och fönster som går att öppna och stänga. Material för att tillverka detta kommer att bestå av wellpapp, korrugerad plast, masonit, tejp, maskeringstejp, skruvar, muttrar, gångjärn, lim, piprensare. Det kommer också att finnas lite olika verktyg att tillgå, exempelvis skruvdragare, skruvmejsel, drillborr och limpistol. Barnen ska endast använda en slags lösning till per dörr/lucka. Omde använder ett sätt på den första dörren/luckan måste de använda ett annat sätt till nästa. Rummet/huset och dess ägare kommer också att "könas" för att se hur barnen reagerar på detta. Först kommer bara själva rummet/huset att presenteras för barnen och de kommer tillsammans att få diskutera vem de tror bor i detta. Efter det kommer pedagogerna att lyfta in per- 
sonen som bor i huset. Tanken är att denna person ska bryta mot traditionella könsmönster. Är det ett "kvinnligt” kodat inrett hus så ska ägaren vara någon slags manlig arketyp eller vice versa (det slutade med att gruppen valde det första alternativet).

\section{Mötesaktion 7}

Större delen av mötesaktion 7, som skedde den 9:e december, gick åt till att färdigställa husen inför verksamhetsaktion 2.

\section{Mötesaktion 8}

Mötesaktionen hölls fredagen den 22 januari 2016. Jag började med att sammanfatta vad som sagts under mötesaktion 6 och 7 . Detta gjordes delvis på grund av att alla deltagarna inte var närvarande på dessa två mötesaktioner, men också på grund av att deltagarna själva uttryckte att de inte hade haft någon tid att fundera på den kommande verksamhetsaktionen under de dryga sex veckor som förflutit sedan sist vi träffades. Det visade sig också att Malin blivit långtidssjukskriven och därför inte längre kunde vara med i studien.

En stor del av mötesaktion 8 gick åt till att vi, i detalj, planerade och strukturerade upp den kommande verksamhetsaktionen, vilken skulle genomföras en vecka senare.

Mötet utmynnade i följande upplägg. Under v.4 skulle teknikpromenader genomföras som en förberedelse inför den kommande verksamhetsaktionen. Fokus på teknikpromenaden skulle vara funktionen öppna/stänga. Promenaden behövde inte enbart handla om gångjärn utan kunde även handla om andra sätt att öppna och stänga.

\section{Verksamhetsaktion 2}

1. Inför aktionen skulle två, alternativt fyra barn, väljas ut av pedagogen/pedagogerna (en pedagog = två barn, två pedagoger $=$ fyra barn). Denna gång skulle alla ha en pojke och en flicka, alternativt två pojkar och två flickor.

2. Inför aktionen behövde personen som bodde i huset "tillverkas". Under mötesaktionen googlades en bild på 
en lämplig man fram. Denna bild skulle skrivas ut och lamineras i två exemplar för varje avdelning. En stor bild, så att barnen lätt skulle kunna se vad den föreställde, och en mindre bild som var något så när i skala till huset.

3. För att det skulle vara enkelt med tillgång till material skulle verksamhetsaktionen denna gång genomföras i respektive ateljé (de som inte hade tillgång till en sådan skulle istället låna närliggande avdelnings ateljé).

4. Aktionen skulle starta med att huset visades för barnen och att pedagogen skulle fråga barnen vem de trodde bodde i huset, och varför de trodde detta. Efter detta skulle den laminerade mannen plockas fram och pedagogen skulle förklara att det var han som bodde i huset.

5. Barnen skulle sedan få i uppgift att konstruera åtminstone två dörrar till huset, båda dörrarna skulle gå att öppna och stänga (fanns det tid över kunde barnen även tillverka fönster/fönsterluckor).

6. Efter detta skulle pedagogerna och barnen tillsammans gå igenom det material som fanns tillgängligt.

Konstruktionsmaterial

Wellpapp

Korrugerad plast

Masonit (försågad av mig i dörrhålens storlek)

Limstift

Smältlim

Limpistol

Maskeringstejp

Vanlig tejp

Piprensare (tunna, vita)

Garn

Gångjärn med skruvar och muttrar 
Handverktyg

Skruvdragare med borr

Drillborr

Tving

Sax

Skruvmejsel

7. Barnen skulle få välja material helt fritt för det första dörrbladet.

8. Om barnen inte använt sig av gångjärnen/skruvarna/muttrarna till den första lösningen skulle de sedan bli ombedda att göra det till lösning nummer två. Hade de däremot använt sig av dessa material i lösning nummer ett kunde de använda annat material för det andra dörrbladet.

9. Barnen skulle även få designa utsidan av sina dörrar. För detta ändamål skulle de tillgång till följande material:

Folie

Kritor/färgpennor/tuschpennor

Pärlor (olika storlekar och material)

Limstift

Glanspapper

10. Till sist skulle barnen och pedagogerna reflektera över och diskutera vilken lösning de tyckte var den bästa.

\section{Verksamhetsaktion 2}

Även denna verksamhetsaktion videofilmades, vilket återigen resulterade i fem filmer på sammanlagt sju till åtta timmar. Jag plockade även denna gång ut intressanta trådar som kunde kopplas till det identifierade utvecklingsområdet och synliggjorde dessa genom ett antal filmsekvenser på några minuter vardera.

Vad det gällde ledarrollen handlade filmsekvenserna om hur barnen positionerade sig i förhållande till varandra och till pedago- 
gerna under aktiviteten, samt vilket utrymme pedagogerna gav barnen och hur de bemötte barnen.

De andra filmsekvenserna fokuserade på barnens sätt att diskutera utifrån verksamhetsaktionens kontext av huset och husets ägare, samt på vilket sätt barnen reflekterade över sina lösningar utifrån val av material till dörren.

\section{Mötesaktion 9}

Onsdagen den 17/2 samlades vi för mötesaktion 9. Under denna tittade vi på, och diskuterade, filmsekvenserna från verksamhetsaktion 2. Mest fokus under detta möte fick frågor gällande hur barnen och pedagogerna agerade i aktiviteterna, både i mötet med varandra och med materialet.

Filmklippen belyste hur barnen positionerade sig i förhållande till materialet, pedagogerna och varandra. Här visade det sig att det gick att se liknande mönster i de olika aktiviteterna. Det var i synnerhet vissa av pojkarna som hela tiden positionerade sig närmast materialet, och ibland - bokstavligen - trängde de sig mellan materialet och pedagogen, och knuffade ut de andra barnen till kanterna. Det kunde också handla om att vissa barn skaffade sig fördelar i aktiviteten, antingen på verbal väg genom att exempelvis uttrycka att de var först i kön när det skulle borras, eller genom att de plockade saker ur händerna på de andra barnen. Filmklippen belyste även att pedagogerna gav betydligt mer uppmärksamhet, uppmuntran och förtroende till pojkarna än till flickorna.

Överlag var deltagarna aningen chockade av detta och uttryckte att mycket av det som de nu såg på filmerna hade de helt missat under själva verksamhetsaktionerna. De menade också att de hade trott att de vara betydligt bättre på att identifiera och uppmärksamma dessa strukturer. Under mötet kom vi fram till några olika idéer på åtgärder för att motverka dessa strukturer i nästa verksamhetsaktion. Bland annat diskuterade vi att en möjlig väg kunde vara att pedagogerna axlade olika roller, där den ena skulle ha som uppgift att fokusera på barnens uppdrag medan den andre skulle fokusera på samspelet. En stor del av tiden gick dock 
åt till att deltagarna diskuterade kring möjliga förklaringar till varför de agerade som de gjorde på filmklippen. Mötet avslutades med att vi bestämde att vid nästa mötesaktion, den 16:e mars, diskutera mer ingående kring lösningar på de problem vi just observerat. Som hjälp inför denna diskussion lovade jag att snarast maila ut transkriptionerna från mötesaktion 9.

\section{Mötesaktion 10}

Mötesaktionen öppnades med att jag kort sammanfattade vad vi fokuserat på vid föregående tillfälle. Efter detta berättade jag att vi denna dag skulle dela upp oss i två grupper för att se till att så många som möjligt kunde komma till tals. Beroende på att det var en del bortfall blev det en grupp på tre och ett par, vilka placerade sig i varsitt rum. För att diskussionerna skulle hålla sig till möjliga lösningar på det problem gällande pedagogernas agerande som vi identifierat under föregående träff så hade jag förberett ett formulär med några olika frågeställningar. Dessa frågeställningar var framtagna utifrån gruppens diskussioner. Jag lade också till några underfrågor till varje fråga för att låta deltagarna diskutera problemet på lite olika nivåer; en planeringsnivå (hur ska aktiviteten förberedas?), en personlig förberedelsenivå (hur kan jag som pedagog förbereda mig så att jag inte faller in i invanda mönster?) och en här-och-nu-nivå (vad gör jag som pedagog om vissa situationer ändå uppstår i aktiviteten?).

$>$ Hur gör ni för att inte haka på det barn som är snabbast och visar intresse först?

Varför hakar ni på den som är snabbast?

Hur kan ni planera aktionen så att detta inte sker?

Hur kan ni som pedagoger förbereda er själva inför aktiviteten?

Hur får ni syn på när detta sker i aktiviteten?

Hur kan ni agera i själva aktiviteten för att motverka detta?

> Hur ser ni till att vissa pojkar inte positionerar sig i mitten/först och trycker bort flickorna till kanterna?

Varför tror ni att de gör detta?

Varför låter ni dem göra det? 
Hur kan ni planera aktiviteten så att detta inte sker? Hur kan ni planera miljön/materialet så att detta inte sker?

Hur kan ni som pedagoger förbereda er själva införaktiviteten?

Hur får ni syn på när detta sker i aktiviteten?

Hur kan ni agera i själva aktiviteten för att motverka detta?

$>$ Hur ser ni till att det inte enbart är vissa pojkar som tar makten över materialet som används?

Varför tror ni att de gör detta?

Varför låter ni dem göra det?

Hur kan ni planera aktiviteten så att detta inte sker?

Hur kan ni planera miljön/materialet så att detta inte sker?

Hur kan ni som pedagoger förbereda er själva inför aktiviteten?

Hur får ni syn på när detta sker i aktiviteten?

Hur kan ni agera i själva aktiviteten för att motverka detta?

$>$ Hur ser ni till att även dessa pojkar är intresserade när flickorna använder sig av materialet?

Varför tror ni att de inte är intresserade?

Hur kan ni planera aktiviteten så att detta inte sker?

Hur kan ni planera miljön/materialet så att detta inte sker?

Hur kan ni som pedagoger förbereda er själva inför aktiviteten?

Hur får ni syn på när detta sker i aktiviteten?

Vi samlades igen efter cirka 75 minuter för att sammanfatta vad som sagts.

I planeringen

- Barnen kan få bestämda platser för att motverka att några hela tiden positionerar sig i centrum, exempelvis skulle de kunna få varsin stol. Detta skulle kunna ge struktur och 
göra det lätt att uppmärksamma barn på att de lämnat sin plats. Däremot skulle det kunna ställa till problem med att alla inte ser materialet samtidigt, exempelvis den delen av huset där dörren sattes fast.

- Ett runt bord. Ingen hamnar i centrum och det blir lika långt för alla till materialet.

- Om det är två pedagoger går det att dela upp olika ansvarsområden, den ena är mer fokuserad på den tekniska aktiviteten och själva görandet medan den andra är mer fokuserad på hur barnen agerar.

- Skapa grupper som jobbar bra tillsammans.

- Koppla in hemmet. Förbereda eller slutföra arbetet hemma.

- Materialet placeras på samma bord som barnen sitter vid. Om det måste finnas ett materialbord behöver inte alla barn gå dit samtidigt.

- Planera aktiviteten utifrån att det är resan som är viktigast inte produkten.

- Planera problemlösningen utifrån att alla ska göra en individuell skiss. Detta kan ge alla chansen att fă den tid de behöver för att tänka. De som är snabba kan dessutom göra fler skisser. Efter detta kan alla få presentera sina idéer och tillsammans kan barnen komma överens om hur den slutliga lösningen ska se ut. Om det finns en problematik med status i gruppen kan pedagogen istället presentera de olika idéerna.

I genomförandet

- Teckenstopp - en gest som betyder "jag vet att du kan men nu vill jag höra hur de andra tänker".

- Dela upp talutrymmet och inte, som pedagog, haka på den som sprutar ut idéer snabbast.

- Bygga gemenskap - lägga tonvikten på att uppdraget ska lösas tillsammans.

- Ha fokus på ledarskap och förhållningssätt, inte enbart på uppgiften.

- Vara mer tydlig mot de barn som tar för stor plats - "Nu tryckte du dig faktiskt före din kamrat/mig”. 
- Vara aktivt medveten om sina kartlagda svagheter (se nedan).

- Informera barnet i början av aktiviteterna om att alla som vill, kommer att få pröva - "alla kommer att få borra, jag kommer att hjälpa alla".

Att få syn på sig själv

- Viktigt att pedagogen före själva aktiviteten kartlägger sina svagheter. Detta kan exempelvis göras genom att filma sig själv eller genom att en kollega observerar aktiviteten (dock behövs någon slags mall eller protokoll, den som observerar behöver veta vad den tittar efter).

\section{Mötesaktion 11}

Inför mötesaktion 11, den 13/4, mailade jag ut ett protokoll av de lösningar angående ledarrollen som hade diskuterats under mötesaktion 10. Detta gjordes både för att påminna de fem deltagare som var med på mötet om vad vi kommit fram till, men även för att ge de andra en inblick i vad som sagts. Mötesaktionen startade med att vi kort diskuterade dessa åtgärder och vilka av dem som var rimliga att ta med oss in i verksamhetaktion 3 .

Efter detta fortsatte vi med att diskutera de filmsekvenser från verksamhetsaktion 2 som fokuserade på den könade kontexten samt den tekniska problemlösningen. Överlag kunde vi konstatera att verksamhetsaktion 2 inte gav någon djupare information om barnens stereotypa/icke-sterotypa syn. De flesta av barnen kopplade helt enkelt huset till en fantasifigur eller en ickemänsklig varelse, i det här fallet till grodan och hans vänner eller till något annat djur. Hos en av de äldre grupperna gick det dock att se spår av något slags stereotypt synsätt då de trodde att det var en av avdelningens dockor (se bild nedan) som bodde i huset. De yngre barnen hade mycket svårare att komma med idéer på vem som kunde bo i huset. Förutom att de angav att det var de själva som bodde i det så gav de inte särskilt många förslag. Pedagogerna fick under verksamhetsaktionen därför rätt så snabbt gå vidare och visa upp den laminerade mannen. När mannen väl plockades fram hade de yngre barnen heller inga direkta tankar om vad han gjorde (yrke, hobbies, och så vidare) medan de äldre 
barnen föreslog att han var chef eller pilot baserat på att han hade en kostym.

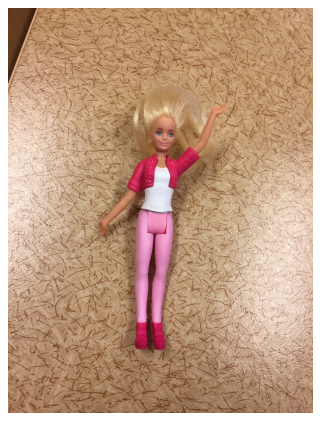

Allt detta utmynnade i att vi bestämde oss för att i nästa verksamhetsaktion istället ha ett flertal olika människor på bild. Detta skulle även för vissa barn, i synnerhet de yngre, kunna fungera som ett bildstöd så att de enklare skulle ha möjlighet att kunna artikulera sina tankar.

Vi pratade också om att förändra kontexten av aktionen och istället för ett hus använda oss av något annat och se om detta skulle kunna ge oss mer information angående stereotypa synsätt hos barnen. I slutändan blev den nya kontexten en bil. Problemlösningen skulle däremot fortfarande handla om att öppna/stänga. Ett förslag var att bilen skulle sakna bagagelucka och att barnens uppgift skulle vara att konstruera en fungerande sådan.

Vad det gäller barnens sätt att ta sig an den tekniska aktiviteten och reflektera över problemlösningsarbetet kunde vi konstatera att ett av problemen var att de olika materialen för dörrbladet i verksamhetsaktion 2 hade olika form. Masoniten hade exakt samma form som dörrhålet, medan plasten och wellpappen var skuren i betydligt större ark. Barnen valde material beroende på form och inte beroende på materialet i sig. Det bestämdes därför att allt material skulle ha samma form i nästa verksamhetsaktion. Deltagarna menade också att vi borde ändra hur problemet presenterades. I verksamhetsaktion 2 angav pedagogerna för barnen att deras uppdrag vara att skapa en dörr som gick att öppna och stänga. Deras uppgift borde kanske istället ha varit att skapa en dörr som gick att öppna och stänga, men att den också skulle vara 
så hållbar som möjligt. I verksamhetsaktion 2 frågade pedagogerna endast barnen vilken lösning de tyckte var "bäst", men preciserade inte vad detta handlade om. Gruppen kom fram till att det kanske inte var nödvändigt att göra två lösningar utan att istället låta barnen lösa problemet och i denna process diskutera alternativa lösningar med dem. Till sist diskuterade vi att även nästa aktion borde starta med en teknikpromenad som handlade om att öppna/stänga, men att denna då även skulle innehålla en bil.

\section{Mötesaktion 12}

Större delen av möte 12 handlade om att planera upp verksamhetsaktion 3 som skulle utföras cirka en vecka senare. Mötet resulterade i följande "körschema".

\section{Inför verksamhetsaktionen}

Innan verksamhetsaktion kommer barnen att gå på en teknikpromenad som handlar om olika sätt att öppna och stänga. Viktigt är att denna gång ta med en bil i promenaden.

\section{Under verksamhetsaktionen}

Alla barn ska få en fast plats. Dessa platser bör signaleras mycket tydligt, exempelvis i form av namnlappar. Formen på bordet är inte så viktigt så länge pedagogen ser till att förflytta materialet så att alla ser. Verktyg och annat material ska inte finnas på ett separat bord utan plockas istället fram vid behov.

Verksamhetsaktionen ska bestå av två pedagoger och fyra barn (två pojkar och två flickor). Den ena pedagogen har som huvuduppgift att jobba med den tekniska aktiviteten medan den andra pedagogen har fokus på genusstrukturer. Den första pedagogen kan då lägga sin uppmärksamhet på barnens konstruktionsarbete, medan den andra pedagogen är uppmärksam på om ett barn lämnar sin plats eller tar materialet från någon annan - "Ja, fast nu var det ju faktiskt Pedros tur", "Oj, men nu är du inte längre på din plats”, "Nu får du komma tillbaka till bordet annars missar du ju när Elsa sätter fast gångjärnet”, och så vidare. Denna pedagog har också i uppgift att uppmärksamma så att alla barn făr utrymme i aktiviteten. 
Under verksamhetsaktionen är det viktigt att visa för entusiastiska barn att - "jag ser att du har en idé, men nu vill jag höra vad de andra har att säga", "Jag vet att du kan, du ska snart få delge oss andra dina idéer". Det kan också handla om att i introduktionen av materialet förklara för barnen att alla ska få pröva - "det här är en drillborr, den kommer ni alla att få testa idag”.

För att inte barnen ska påverka varandra i sitt val av vem de tror är ägare till bilen, kommer de att få diskutera detta enskilt med en av pedagogerna. Under tiden som detta sker tar den andre pedagogen hand om övriga tre barn. När alla barn har fătt diskutera frågan samlas de fyra barnen och de två pedagogerna och diskuterar frågan tillsammans. Här blir det intressant att se om barnen ändrar sin motivering. Både den enskilda diskussionen och gruppdiskussionen utgår från sex stycken olika människor (tre kvinnor och tre män). Vem tror barnet är ägare av bilen? Varför tror hen det?

Efter detta introduceras problemet. Pedagogerna förklarar för barnet att bilen saknar bagagelucka och att uppgiften är att konstruera en lucka som är enkel att öppna och stänga, samtidigt som den är så hållbar som möjligt. I samband med detta introduceras också materialet och de olika verktygen. Efter detta får barnen var för sig göra en skiss på hur de tänker sig att problemet kan lösas. När de är klara med detta diskuteras de olika lösningsförslagen i gruppen. Till sist plockas skisserna bort och barnen får nu i uppgift att konstruera en lucka tillsammans.

\section{Verksamhetsaktion 3}

I verksamhetsaktion 3 videofilmades fyra aktiviteter, det vill säga en mindre än föregående verksamhetsaktioner. Det eftersom att vi hade bestämt att det i varje grupp skulle finnas två pedagoger och fyra barn. Detta resulterade i sex till sju timmar inspelat material. Precis som i föregående verksamhetsaktioner analyserades sedan det inspelade materialet av mig under efterkommande vecka och klipptes samman till några filmsekvenser som visades för deltagarna under den efterföljande mötesaktionen. 


\section{Mötesaktion 13}

Mötesaktion 13 genomfördes i juni 2017 och detta var gruppens sista officiella möte, och som sådant hade det en del att önska. Tyvärr var det endast fyra deltagare som kunde vara med, detta på grund av semester, personalbrist och sjukdom. Mötesaktionen startade med att gruppen diskuterade fritt utifrån hur de upplevt respektive verksamhetsaktion 3 (tre av de fyra avdelningar var representerade på mötet). Deltagarna uttryckte att de ansåg att barnen i verksamhetsaktion 3 överlag hade varit betydligt mer lugna och metodiska än de i verksamhetsaktion 1 och 2, och att talutrymmet denna gång hade varit mer jämnt fördelat mellan barnen. Deltagarna var snabba med att beskriva att de tyckte att de fasta platserna gjorde att aktiviteten blev tydligare i form av att barnen inte "flaxade" runt och/eller tog plats på bekostnad av någon annan. De menade också att en annan faktor som verkade positivt ur detta perspektiv var deras tydlighet gentemot barnen om att det var de, som pedagoger, som plockade fram materialet till barnens bord. De påtalade även att de under den här aktiviteten hade varit mer medvetna om att använda teckenstopp för att bekräfta, men samtidigt "dämpa", vissa barn. De påpekade att de kunde se att uppdelningen i olika pedagogroller hade gett en positiv effekt i och med att det under aktiviteten hade varit lättare att upptäcka när ett barn tog för sig på bekostnad av ett annat. Dock hade de varit lite olika tydliga i sin uppdelning. Några beskrev att de hade varit relativt strikta i sin uppdelning av vem som hade vilken roll. Andra hade inte haft en lika strikt uppdelning av rollerna, men utgångspunkten hade ändå varit att en av dem hade haft mer fokus på uppdraget och en hade haft mer fokus på samspelet. Anledningen till att de inte valde att vara så strikta i sin uppdelning handlade om att de själva tyckte att de genom samspelet pedagog-pedagog kunde bekräfta och stärka varandra, samt att detta var en smidigare uppdelning eftersom det påminner mer om deras vanliga sätt att arbeta på. Deltagarna tyckte till sist att genomförandet med skisserna överlag hade fungerat bra och att de var förvånade över att barnen kunde släppa sina egna idéer och skisser så pass snabbt som de gjorde, för att istället gemensamt i grupp komma fram till en lösning. 
Av den resterande mötestiden gick det mesta åt till att diskutera ledarskapet. På grund av tidsbrist fick inte synliggörandet av tekniken lika stor plats. Jag hade återigen förberett några filmklipp. En filmsekvens belyste kortfattat hur arbetet i en av grupperna sett ut utifrån att pedagogerna bekräftade ett barns idéer samtidigt som de såg till att alla fick komma till tals. I gruppen fanns ett barn som hade väldigt bra koll på det mesta av materialet och som även hade tydliga idéer på hur problemet skulle lösas. Pedagogerna menade att de medvetet under aktiviteten hade försökt visa för detta barn att de såg att han kunde men att det var viktigt att han även lyssnade på de andra barnens idéer också. De menade att detta var något som han verkade ha tagit till sig. De sa att om de inte hade "hållit tillbaka" honom på det här sättet hade troligtvis inte de andra barnen fått komma till tals i samma utsträckning. Deltagarna menade även att alla barn kanske inte hade haft lika lätt att få ned sina tankar på papper, men i slutändan menade de ändå att skisserna verkade positivt för utfallet av aktiviteten, i synnerhet för dem själva som ledare. I vanliga fall hade de kanske varit betydligt snabbare med att gå vidare med själva konstruerandet, men på grund av skissandet blev de nu tvungna att stanna upp och låta barnen fundera. De beskrev även att detta blev ett tillfälle där de barn som inte hade så mycket erfarenheter kunde lära av de barn som hade detta. Filmsekvenserna visade också att deltagarna var väldigt medvetna om att kontinuerligt påpeka för barnen att alla skulle få möjlighet att testa verktygen och få tillgång till materialet.

Filmsekvenserna visade också att det fanns tillfällen där de delade rollerna gav en tydlig effekt. Dessa tillfällen handlade till stor del om att den pedagog som hade till uppgift att observera samspelet gjorde den andra pedagogen uppmärksam, antingen med hjälp av tecken eller ord, på att det fanns fler barn som ville komma till tals eller som den andra pedagogen skulle kunna vända sig till.

Deltagarna var även förvånade över vilka fantastiska spår de hade kunnat se av verksamhetsaktionerna i övriga aktiviteter och den allmänna vardagen på förskolan. Exempelvis beskrev några att de, dagen före mötesaktion 13, varit på ett besök på ett slott i 
närheten där många av barnen varit väldigt uppmärksamma på gångärnen på de gamla dörrarna. De hade även under hela våren sett hur barnen, i synnerhet många av flickorna, byggde egna vad de kallade - "teknikhus".

Efter detta tittade vi på en filmsekvens där verksamhetsaktion 2 jämfördes med verksamhetsaktion 3. Deltagarna kunde genom detta bekräfta sin känsla av att verksamhetsaktion 3 hade varit mer strukturerad och tydlig för barnen än den föregående. Bland annat uttryckte de att det gick att se att barnen i verksamhetsaktion 3 samarbetade och lyssnade mer på varandra, mycket beroende på att pedagogerna som ledare såg till att det inte var några barn som tog plats på bekostnad av andra. De menade också att det blev tydligt att de fasta platserna gjorde så att det inte gick att "armbåga" sig före.

Utifrån filmerna kom vi också in på diskussioner om hur pedagogerna hade jobbat med att låta barnen fundera över vilket material som var mest hållbart. Deltagarna kunde konstatera att de sinsemellan jobbat ganska annorlunda med detta. Exempelvis så lät några pedagoger barnen böja och bända på pappen, plasten och masoniten för att avgöra vilket material de ansåg vara mest stabilt. I detta fallet medförde det att barnen väldigt snabbt kunde komma överens om att masonit var betydligt mer stabil än plasten eller pappen. 
Studies in Science and Technology Education

ISSN 1652-5051

1. Margareta Enghag (2004): MINIPROJECTS AND CONTEXT RICH PROBLEMS - Case studies with qualitative analysis of motivation, learner ownership and competence in small group work in physics. (licentiate thesis) Linköping University

2. Carl-Johan Rundgren (2006): Meaning-Making in Molecular Life Science Education - upper secondary school students' interpretation of visualizations of proteins. (licentiate thesis) Linköping University

3. Michal Drechsler (2005): Textbooks', teachers', and students' understanding of models used to explain acid-base reactions. ISSN: 1403-8099, ISBN: 91-85335-40-1. (licentiate thesis) Karlstad University

4. Margareta Enghag (2007): Two dimensions of Student Ownership of Learning during Small-Group Work with Miniprojects and context rich Problems in Physics. ISSN: 1651-4238, ISBN: 91-85485-31-4. (Doctoral Dissertation) Mälardalen University

5. Maria Åström (2007): Integrated and Subject-specific. An empirical exploration of Science education in Swedish compulsory schools. (Licentiate thesis) Linköping university

6. Ola Magntorn (2007): Reading Nature: developing ecological literacy through teaching. (Doctoral Dissertation) Linköping University

7. Maria Andreé (2007): Den levda läroplanen. En studie av naturorienterande undervisningspraktiker i grundskolan. ISSN: 1400-478X, HLS Förlag: ISBN 978-91-7656-632-9 (Doctoral Dissertation, LHS)

8. Mattias Lundin (2007): Students' participation in the realization of school science activities.(Doctoral Dissertation) Linköping University

9. Michal Drechsler (2007): Models in chemistry education. A study of teaching and learning acids and bases in Swedish upper secondary schools ISBN 978-91-7063-112-2 (Doctoral Dissertation) Karlstad University

10. Proceedings from FontD Vadstena-meeting, April 2006.

11. Eva Blomdahl (2007): Teknik i skolan. En studie av teknikundervisning för yngre skolbarn. ISSN: 1400-478X, HLS Förlag: ISBN 978-91-7656-635-0 (Doctoral Dissertation, LHS) 
Studies in Science and Technology Education

ISSN 1652-5051

12. Iann Lundegård (2007): På väg mot pluralism. Elever i situerade samtal kring hållbar utveckling. ISSN:1400-478X, HLS Förlag: ISBN 978-91-7656-642-8 (Doctoral Dissertation, LHS)

13. Lena Hansson (2007): "Enligt fysiken eller enligt mig själv?” Gymnasieelever, fysiken och grundantaganden om världen. (Doctoral Dissertation) Linköping University.

14. Christel Persson (2008): Sfärernas symfoni i förändring? Lärande i miljö för hållbar utveckling med naturvetenskaplig utgångspunkt. En longitudinell studie i grundskolans tidigare årskurser. (Doctoral Dissertation) Linköping University

15. Eva Davidsson (2008): Different Images of Science - a study of how science is constituted in exhibitions. ISBN: 978-91-9771001-5 (Doctoral Dissertation) Malmö University

16. Magnus Hultén (2008): Naturens kanon. Formering och förändring av innehållet i folkskolans och grundskolans naturvetenskap 1842-2007. ISBN: 978-91-7155-612-7 (Doctoral Dissertation) Stockholm University

17. Lars-Erik Björklund (2008): Från Novis till Expert: Förtrogenhetskunskap i kognitiv och didaktisk belysning. (Doctoral Dissertation) Linköping University.

18. Anders Jönsson (2008): Educative assessment for/of teacher competency. A study of assessment and learning in the "Interactive examination” for student teachers. ISBN: 978-91-977100-39 (Doctoral Dissertation) Malmö University

19. Pernilla Nilsson (2008): Learning to teach and teaching to learn - primary science student teachers' complex journey from learners to teachers. (Doctoral Dissertation) Linköping University

20. Carl-Johan Rundgren (2008): VISUAL THINKING, VISUAL SPEECH - a Semiotic Perspective on Meaning-Making in Molecular Life Science. (Doctoral Dissertation) Linköping University

21. Per Sund (2008): Att urskilja selektiva traditioner i miljöundervisningens socialisationsinnehåll - implikationer för undervisning för hållbar utveckling. ISBN: 978-91-85485-88-8 (Doctoral Dissertation) Mälardalen University

22. Susanne Engström (2008): Fysiken spelar roll! I undervisning om hållbara energisystem - fokus på gymnasiekursen Fysik A. ISBN: 978-91-85485-96-3 (Licentiate thesis) Mälardalen University 
Studies in Science and Technology Education

ISSN 1652-5051

23. Britt Jakobsson (2008): Learning science through aesthetic experience in elementary school science. Aesthetic judgement, metaphor and art. ISBN: 978-91-7155-654-7. (Doctoral Dissertation) Stockholm university

24. Gunilla Gunnarsson (2008): Den laborativa klassrumsverksamhetens interaktioner - En studie om vilket meningsskapande år 7-elever kan erbjudas i möten med den laborativa verksamhetens instruktioner, artefakter och språk inom elementär ellära, samt om lärares didaktiska handlingsmönster i dessa möten.

(Doctoral Dissertation) Linköping University

25. Pernilla Granklint Enochson (2008): Elevernas föreställningar om kroppens organ och kroppens hälsa utifrån ett skolsammanhang. (Licentiate thesis) Linköping University

26. Maria Åström (2008): Defining Integrated Science Education and putting it to test (Doctoral Dissertation) Linköping University

27. Niklas Gericke (2009): Science versus School-science. Multiple models in genetics - The depiction of gene function in upper secondary textbooks and its influence on students' understanding. ISBN 978-91-7063-205-1 (Doctoral Dissertation) Karlstad University

28. Per Högström (2009): Laborativt arbete i grundskolans senare år - lärares mål och hur de implementeras. ISBN 978-91-7264755-8 (Doctoral Dissertation) Umeå University

29. Annette Johnsson (2009): Dialogues on the Net. Power structures in asynchronous discussions in the context of a web based teacher training course. ISBN 978-91-977100-9-1 (Doctoral Dissertation) Malmö University

30. Elisabet M. Nilsson (2010): Simulated "real" worlds: Actions mediated through computer game play in science education. ISBN 978-91-86295-02-8 (Doctoral Dissertation) Malmö University

31. Lise-Lotte Österlund (2010): Redox models in chemistry: A depiction of the conceptions held by upper secondary school students of redox reactions. ISBN 978-91-7459-053-1 (Doctoral Dissertation) Umeå University

32. Claes Klasander (2010): Talet om tekniska system - förväntningar, traditioner och skolverkligheter. ISBN 978-91-7393332-2 (Doctoral Dissertation) Linköping University 
Studies in Science and Technology Education

ISSN 1652-5051

33. Maria Svensson (2011): Att urskilja tekniska system - didaktiska dimensioner i grundskolan. ISBN 978-91-7393-250-9 (Doctoral Dissertation) Linköping University

34. Nina Christenson (2011): Knowledge, Value and Personal experience - Upper secondary students' use of supporting reasons when arguing socioscientific issues. ISBN 978-91-7063-340-9 (Licentiate thesis) Karlstad University

35. Tor Nilsson (2011): Kemistudenters föreställningar om entalpi och relaterade begrepp. ISBN 978-91-7485-002-4 (Doctoral Dissertation) Mälardalen University

36. Kristina Andersson (2011): Lärare för förändring - att synliggöra och utmana föreställningar om naturvetenskap och genus. ISBN 978-91-7393-222-6 (Doctoral Dissertation) Linköping University

37. Peter Frejd (2011): Mathematical modelling in upper secondary school in Sweden An exploratory study. ISBN: 978-91-7393223-3 (Licentiate thesis) Linköping University

38. Daniel Dufåker (2011): Spectroscopy studies of few particle effects in pyramidal quantum dots. ISBN 978-91-7393-179-3 (Licentiate thesis) Linköping University

39. Auli Arvola Orlander (2011): Med kroppen som insats: Diskursiva spänningsfält i biologiundervisningen på högstadiet. ISBN 978-91-7447-258-5 (Doctoral Dissertation) Stockholm University

40. Karin Stolpe (2011): Att uppmärksamma det väsentliga. Lärares ämnesdidaktiska förmågor ur ett interaktionskognitivt perspektiv. ISBN 978-91-7393-169-4 (Doctoral Dissertation) Linköping University

41. Anna-Karin Westman (2011) Samtal om begreppskartor - en väg till ökad förståelse. ISBN 978-91-86694-43-2 (Licentiate thesis) Mid Sweden University

42. Susanne Engström (2011) Att vördsamt värdesätta eller tryggt trotsa. Gymnasiefysiken, undervisningstraditioner och fysiklärares olika strategier för energiundervisning. ISBN 978-917485-011-6 (Doctoral Dissertation) Mälardalen University

43. Lena Adolfsson (2011) Attityder till naturvetenskap. Förändringar av flickors och pojkars attityder till biologi, fysik och kemi 1995 till 2007. ISBN 978-91-7459-233-7 (Licentiate thesis) Umeå University 
Studies in Science and Technology Education ISSN 1652-5051

44. Anna Lundberg (2011) Proportionalitetsbegreppet i den svenska gymnasie-matematiken - en studie om läromedel och nationella prov. ISBN 978-91-7393-132-8 (Licentiate thesis) Linköping University

45. Sanela Mehanovic (2011) The potential and challenges of the use of dynamic software in upper secondary Mathematics. Students' and teachers' work with integrals in GeoGebra based environments. ISBN 978-91-7393-127-4 (Licentiate thesis) Linköping University

46. Semir Becevic (2011) Klassrumsbedömning i matematik på gymnasieskolans nivå. ISBN 978-91-7393-091-8 (Licentiate thesis) Linköping University

47. Veronica Flodin (2011) Epistemisk drift - genbegreppets variationer i några av forskningens och undervisningens texter i biologi. ISBN 978-91-9795-161-6 (Licentiate thesis) Stockholm University

48. Carola Borg (2011) Utbildning för hållbar utveckling ur ett lärarperspektiv - ̈̈mnesbundna skillnader i gymnasieskolan. ISBN 978-91-7063-377-5 (Licentiate thesis) Karlstad University 49. Mats Lundström (2011) Decision-making in health issues: Teenagers' use of science and other discourses. ISBN 978-9186295-15-8 (Doctoral Dissertation) Malmö University

50. Magnus Oscarsson (2012) Viktigt, men inget för mig. Ungdomars identitetsbygge och attityd till naturvetenskap. ISBN: 97891-7519-988-7 (Doctoral Dissertation) Linköping University

51. Pernilla Granklint Enochson (2012) Om organisation och funktion av människo-kroppens organsystem - analys av elevsvar från Sverige och Sydafrika. $\quad$ ISBN 978-91-7519-960-3 (Doctoral Dissertation) Linköping University

52. Mari Stadig Degerman (2012) Att hantera cellmetabolismens komplexitet - Meningsskapande genom visualisering och metaforer. ISBN 978-01-7519-954-2 (Doctoral Dissertation) Linköping University

53. Anna-Lena Göransson (2012) The Alzheimer A $\beta$ peptide: Identification of Properties Distinctive for Toxic Prefibrillar Species. ISBN 978-91-7519-930-6 (Licentiate thesis) Linköping University 
Studies in Science and Technology Education

ISSN 1652-5051

54. Madelen Bodin (2012) Computational problem solving in university physics education

- Students' beliefs, knowledge, and motivation. ISBN 978-91-

7459-398-3 (Doctoral Dissertation) Umeå University

55. Lena Aretorn (2012) Mathematics in the Swedish Upper Secondary School Electricity Program: A study of teacher knowledge. ISBN 978-91-7459-429-4 (Licentiate thesis) Umeå University

56. Anders Jidesjö (2012) En problematisering av ungdomars intresse för naturvetenskap och teknik i skola och samhälle - Innehåll, medierna och utbildningens funktion. ISBN 978-917519-873-6 (Doctoral Dissertation) Linköping University

57. Thomas Lundblad (2012) Simulerad verklighet i gymnasieskolans fysik: en designstudie om en augmented reality simulering med socio-naturvetenskapligt innehåll. ISBN 978-91-7519-8545 (Licentiate thesis) Linköping University

58. Annie-Maj Johansson (2012) Undersökande arbetssätt i NOundervisningen i grundskolans tidigare årskurser. ISBN 978-917447-552-4 (Doctoral Dissertation) Stockholm University

59. Anna Jobér (2012) Social Class in Science Class. ISBN 978-9186295-31-8 (Doctoral Dissertation) Malmö University

60. Jesper Haglund (2012) Analogical reasoning in science education - connections to semantics and scientific modeling in thermodynamics. ISBN 978-91-7519-773-9 (Doctoral Dissertation) Linköping University

61. Fredrik Jeppsson (2012) Adopting a cognitive semantic approach to understand thermodynamics within science education. ISBN 978-91-7519-765-4 (Doctoral Dissertation) Linköping University

62. Maria Petersson (2012) Lärares beskrivningar av evolution som undervisningsinnehåll i biologi på gymnasiet.ISBN 978-917063-453-6 (Doctoral Dissertation) Karlstad University 
Studies in Science and Technology Education

ISSN 1652-5051

63. Henrik Carlsson (2012) Undervisningsform, klassrumsnormer och matematiska förmågor. En studie av ett lokalt undervisningsförsök för elever med intresse och fallenhet för matematik. ISBN 978-91-86983-89-5 (Licentiate thesis) Linnaeus University)

64. Anna Bergqvist (2012) Models of Chemical Bonding. Representations Used in School Textbooks and by Teachers and their Relation to Students' Understanding. ISBN 978-91-7063-463-5 (Licentiate thesis) Karlstad University

65. Nina Kilbrink (2013) Lära för framtiden: Transfer i teknisk yrkesutbildning. ISBN 978-91-7063-478-9 (Doctoral Dissertation) Karlstad University

66. Caroline Larsson (2013) Experiencing Molecular Processes. The Role of Representations for Students' Conceptual Understanding. ISBN 978-91-7519-607-7 (Doctoral Dissertation) Linköping University

67. Anna-Karin Carstensen (2013) Connect Modelling Learning to Facilitate Linking Models and the Real World through Labwork in Electric Circuit Courses for Engineering Students ISBN 97891-7519-562-9 (Doctoral Dissertation) Linköping University

68. Konferensproceeding: 10-year Anniversary Meeting with the Scientific Committee

69. Marie Bergholm (2014) Gymnasieelevers kommunikativa strategier i matematikklassrummet. En fallstudie av ett smågruppsarbete om derivata ISBN 978-91-7519-306-9 (Licentiate thesis) Linköping University

70. Ingrid Lundh (2014) Undervisa Naturvetenskap genom Inquiry - En studie av två högstadielärare. ISBN 978-91-7519-285-7 (Licentiate thesis) Linköping University

71. Nils Boman (2014) Personality traits in fish - implications for invasion biology

ISBN:978-91-7601-097-6 (Licentiate thesis) Umeå University

72. Torodd Lunde (2014) När läroplan och tradition möts - lärarfortbildning och syften med undersökande aktiviteter inom den laborativa NO-undervisningen i grundskolans senare del. ISBN: 978-91-7063-577-9 (Licentiate thesis) Karlstad University 
Studies in Science and Technology Education

ISSN 1652-5051

73. Martin Eriksson (2014) Att ta ställning - gymnasieelevers argumentation och beslutsfattande om sociovetenskapliga dilemman. ISBN 978-91-7063-588-5 (Licentiate thesis), Karlstad University

74. Annalena Holm (2014) Mathematics Communication within the Frame of Supplemental Instruction. Identifying Learning Conditions. ISBN 978-91-7623-112-8 (Licentiate thesis) Lund University

75. Daniel Olsson (2014) Young people's 'Sustainability Consciousness' - Effects of ESD implementation in Swedish schools. ISBN 978-91-7063-594-6. (Licentiate thesis) Karlstad University

76. Marlene Sjöberg (2014) Möjligheter I kollegiala samtal om NOundervisning och bedömning. https://gupea.ub.gu.se/handle/2077/24063 (Licentiate thesis) Gothenburg University.

77. Teresa Berglund (2014) Student 'Sustainability Consciousness' and Decision-Making on Sustainability Dilemmas. Investigating effects of implementing education for sustainable development in Swedish upper secondary schools. ISBN 978-91-7063-599-1 (Licentiate thesis) Karlstad University

78. Elisabet Mellroth (2014) High achiever! Always a high achiever? A comparison of student achievements on mathematical tests with different aims and goals. ISBN 978-91-7063-607-3 (Licentiate thesis) Karlstad University

79. Jenny Green (2014) Elevers användande av formativ återkoppling i matematik. ISBN 978-91-7519-164-5 (Licentiate thesis) Linköping University

80. Klara Kerekes (2014) Undervisning om växande geometriska mönster-en variationsteoretisk studie om hur lärare behandlar ett matematiskt innehåll på mellanstadiet. ISBN: 978-91-7519135-5 (Licentiate thesis) Linköping University

81. Cecilia Axell (2015) Barnlitteraturens tekniklandskap: en didaktisk vandring från Nils Holgersson till Pettson och Findus. ISBN 978-91-7519-227-7 (Doctoral Dissertation) Linköping University. 
Studies in Science and Technology Education

ISSN 1652-5051

82. Jan Forsgren (2015) Synthesis and characterization of catalysts for hydrogen production from water ISBN 978-91-7601-2062.(Licentiate thesis) Umeå University

83. Maria Eriksson (2015) Att kommunicera naturvetenskap i nationella prov: En studie med andraspråksperspektiv. ISBN 97891-7519-138-6 (Licentiate thesis) Linköping University

84. Tomas Jemsson (2015) Time correlated single photon spectroscopy on pyramidal quantum dots. ISBN 978-91-7519-143-O (Licentiate thesis) Linköping University

85. Helen Hasslöf (2015) The Challenge of Education for Sustainable Development. Qualification, social change and the political ISBN: 978-91-7519-127-O (Doctoral Dissertation) Linköping University.

86. Johan Sidenvall (2015) Att lära sig resonera - Om elevers möjligheter att lära sig resonera matematiskt. ISBN 978-91-7519100-3 (Licentiate thesis) Linköping University.

87. Jonas Jäder (2015) Elevers möjligheter till lärande av matematiska resonemang. ISBN 978-91-7519-099-0 (Licentiate thesis) Linköping University.

88. Laurence Russell (2015) Exploring systematic lesson variation a teaching method in mathematics. ISBN 978-91-7519-041-9 (Licentiate thesis) Linköping University.

89. Roger Andersson (2015). Ett lysande experiment. En studie av lärandeprogressionen vid lärande med datorstöd i optik. ISBN 978-91-7485-215-8 (Licentiate thesis) Mälardalen University.

90. Therese Granekull (2015). Kamratbedömning i naturvetenskap på mellanstadiet - formativ återkoppling genom gruppsamtal. ISBN: 978-91-86295-74-5

(Licentiate thesis) Malmö högskola.

91. Yukiko Asami-Johansson (2015) Designing Mathematics Lessons Using Japanese Problem Solving Oriented Lesson Structure. A Swedish Case Study. ISBN. 978-91-7685-990-2 (Licentiate thesis) Linköping University.

92. Katarina Ottander (2015). Gymnasieelevers diskussioner utifrån hållbar utveckling. Meningsskapande, naturkunskapande, demokratiskapande. ISBN 978-91-7601-322-9 (Doctoral Dissertation) Umeå University 
Studies in Science and Technology Education

ISSN 1652-5051

93. Lena Heikka (2015) Matematiklärares målkommunikation - En jämförelse av elevernas uppfattningar, lärarens beskrivningar och den realiserade undervisningen. ISBN: 978-91-7583-446-7 (Licentiate thesis) Luleå University of Technology

94. Anette Pripp (2016) Välja teknik? Ungdomars röster om valet till gymnasiets teknikprogram. ISBN 978-91-7685-775-5 (Licentiate thesis) Linköping University.

95. Annika Pettersson (2016) Grafisk och algebraisk representation: Gymnasieelevers förståelse av linjära funktioner. ISBN 978-91-7063-705-6 (Licentiate thesis) Karlstad University.

96. Erika Boström (2017) Formativ bedömning: En enkel match eller en svår utmaning?

Effekter av en kompetensutvecklingssatsning på lärarnas praktik och på elevernas prestationer i matematik. ISBN 978-917601-706-7 (Doctoral Dissertation) Umeå University.

97. Gustav Bohlin (2017) Evolving germs - Antibiotic resistance and natural selection in education and public communication. ISBN: 978-91-7685-489-1 (Doctoral Dissertation) Linköping University.

98. Daniel Åkerblom (2018) Meningsfullhet i lärandet - hur kan autenticitet förändra undervisningspraktiken? ISBN: 978-9188761-19-4 (Licentiate thesis) Linnaeus University.

99. Charlotta Nordlöf (2018) Tekniklärares attityder till teknikämnet och teknikundervisningen ISBN 978-91-7685-328-3 (Licentiate thesis) Linköping University.

100. Johan Boström (2018) Teknik i förskolan - att motverka traditionella könsroller: En aktionsforskningsstudie ISBN 978-917685-307-8 (Licentiate thesis) Linköping University 